\title{
العدالة عند أهل الرواية
}

إعداد

د. عبـد الرحهمن بـن عبد الكـريم الزيد

\section{المقدمهـة}

الحمد لله حمدا كثير طيبا مبار كا فيه والصلاة والسلام على رسول الله المبعوث بالرحمة والهدى ودين الحق وعلى آله وصحبه ومن سار على هديه واتبع سنته إلى

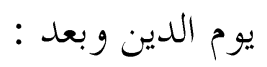

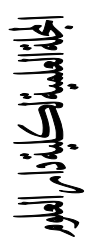
$\varepsilon \cdot 1$

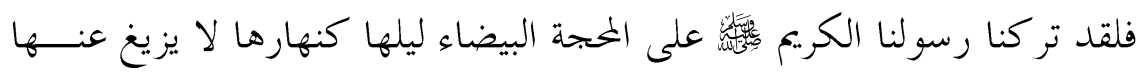

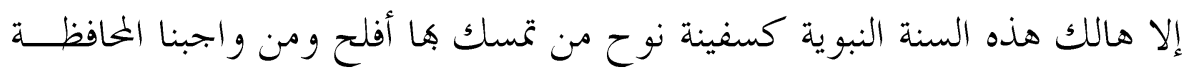

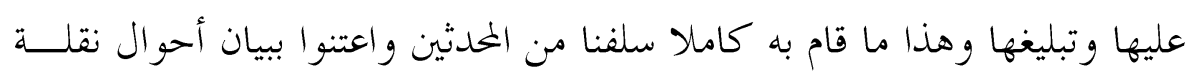

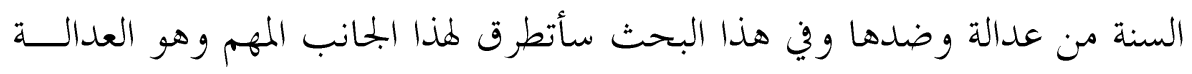

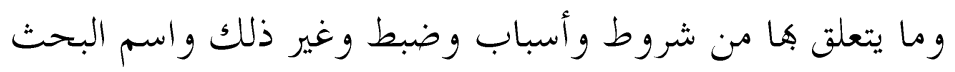
" العدالة عند أهل الرواية " أسأل الله أن ينفع به وأن يرزقنا الإخحاص والئل الصواب

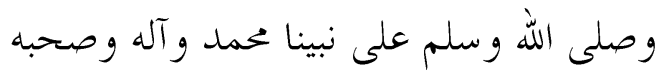
وقد قسمت البحث كالاتي : أولا : تعريف العدالة من حيث اللغة والاصطلاح ثانيا : ذكر شروط العدالة المتنق عليها ثالثا : اشتر اط الأئمة للعدالة لقبول الرواية رابعا : هل الأصل في الراوي العدالة ، فتقبل روايته أو ترد ؟

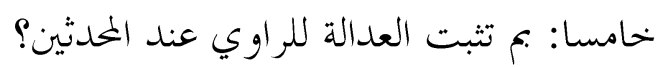
سادسا : حكم تعديل المبهم سابعا : ملازمة العدالة للضبط في مسأله قبول رواية الراوي 
ثامنا : كيف يعرف ضبط الراوي

\section{تعريف العدالة.}

العدالة لغة : مصدر عَدُل بضم الدال ـ تقول عدُل زيد عدالة و العـــل ضـــــ

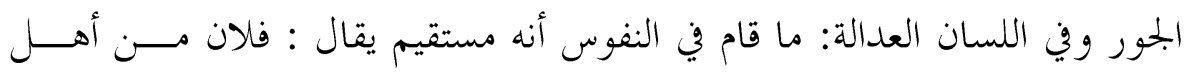

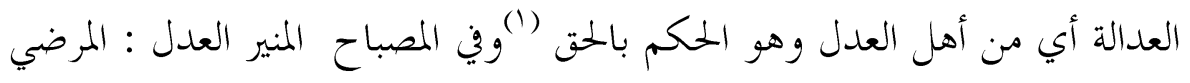

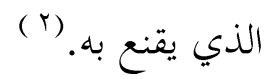

وقال ابن الأثير : التعديل وصف متى التحق بالراوي والشاهد اعتــبر قولمهـ وأخذ به. (r)

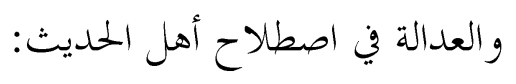

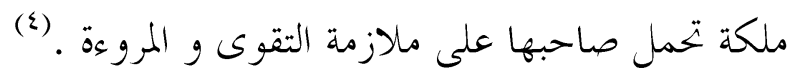

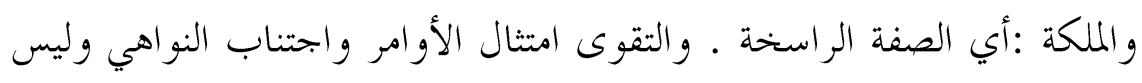

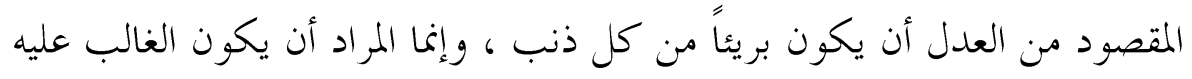
التدين ، و التحري في فعل الطاعات و والمروءة سيأتي تفصيلها.

\section{شـروط العدالة:-}

1-الإسلام ـ فيشترط في الراوي أن يكون مسلماً بالإجماع لقوله تعالى "مــنـ

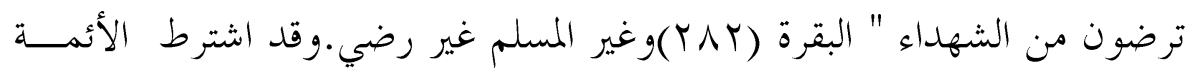

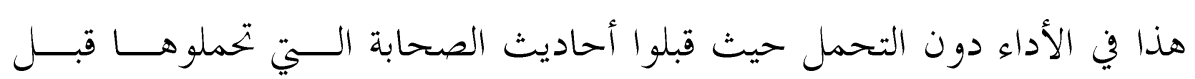

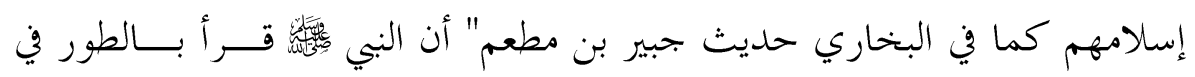

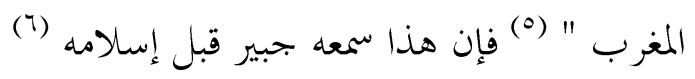

r- البلوغ ويكون بعلاماته المعروفة و اشتُرط البلوغ غلأنه مناط تحمل المسئولية

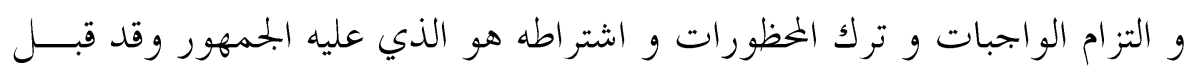

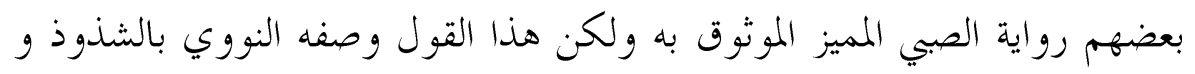

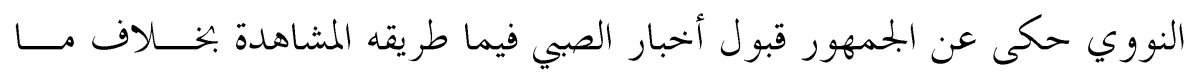

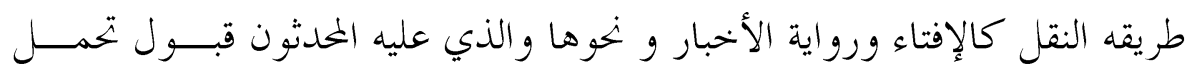


الطفل المميز • إذا بِّغ ما تحمله بعد البلوغ و كان من أهل العدالة و استدلو اعلى

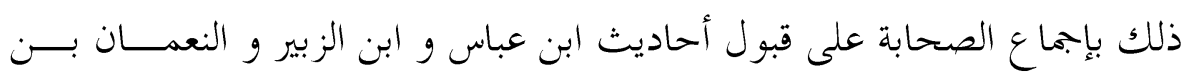

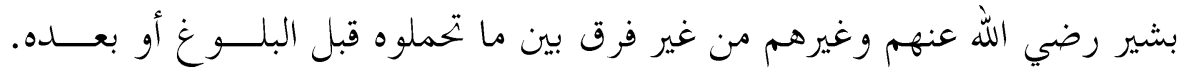

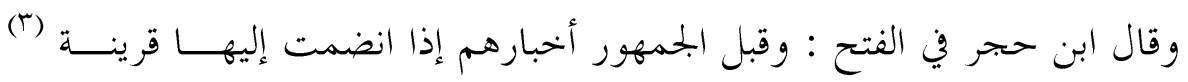
ويظهر أنه يعني بذلك الأداء قبل البلو غ وفين

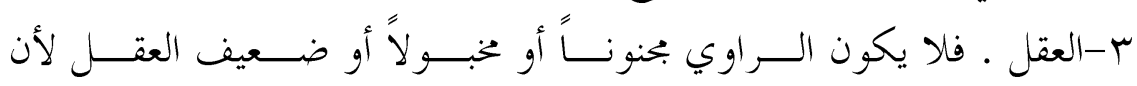
ذلك يمنع من الضبط و ينافي العدالة

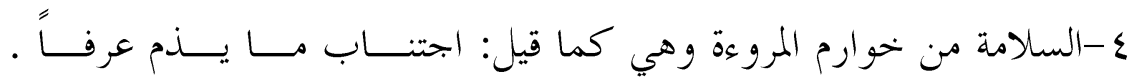

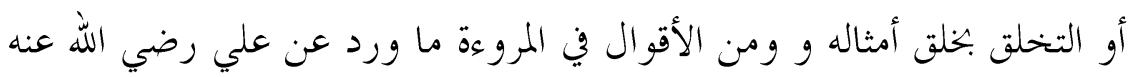

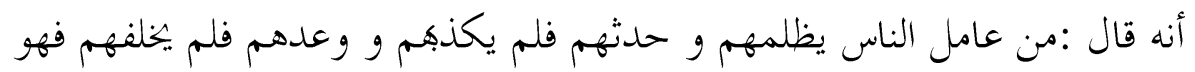

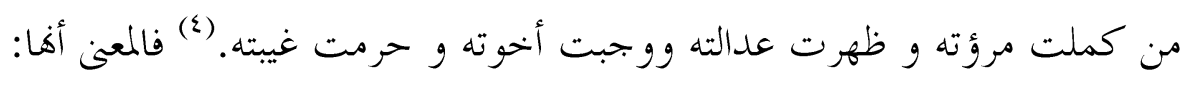

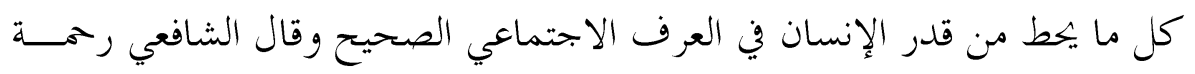

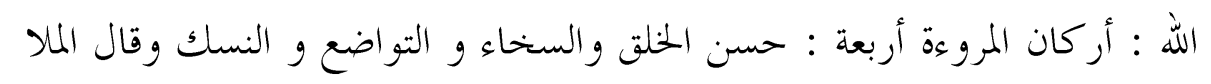

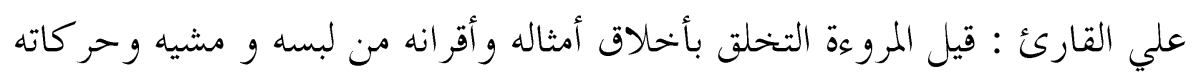
و بتحنب ما لا يليق كالبول في الطريق وصحبة الأراذل و اللعب بالحمام و أمثـــال

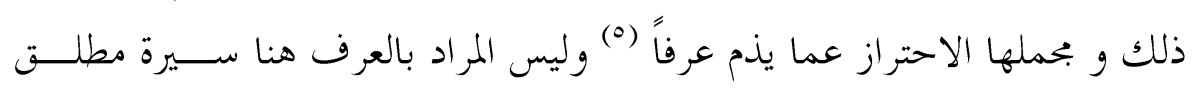

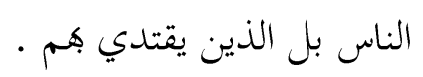
وذكر الماوردي أن الذي بتحبه شرط في العدالة : ما سخف من الكاملام المؤذي

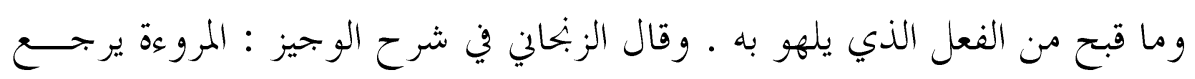

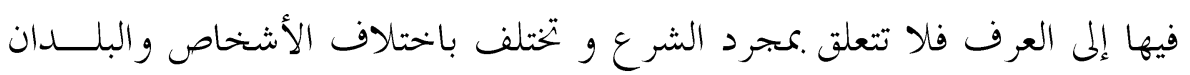

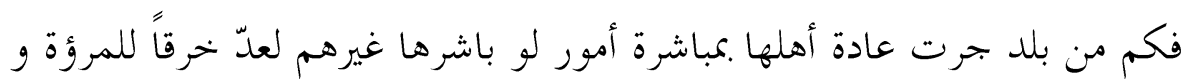

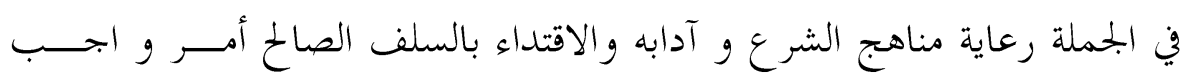
الرعاية. 
و قد نازع بعض العلماء في اشتراط السلامة من خوارم المرووة حتى أن الخطيب

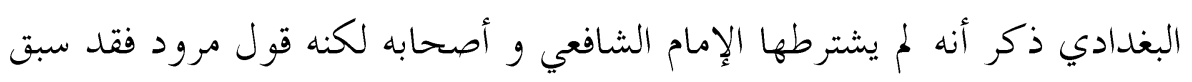

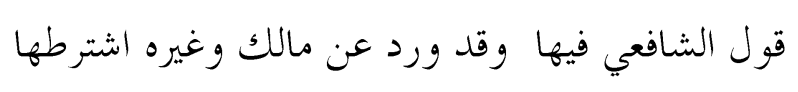

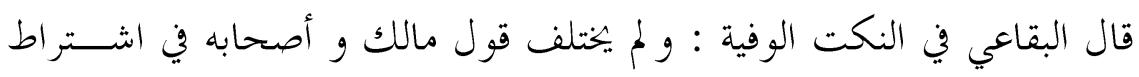

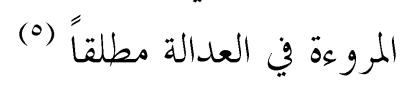

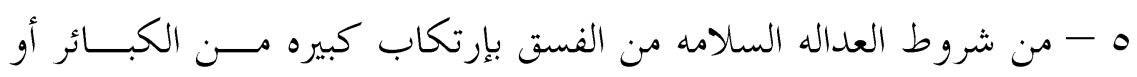
إصرار علي صغيره أو علي مباح يخل بالمروءة وهي كمال النفس بالترفع عن الدنايا

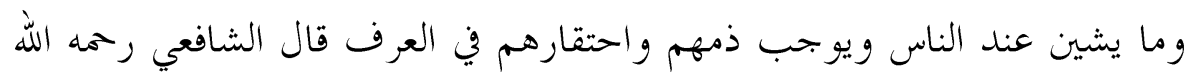

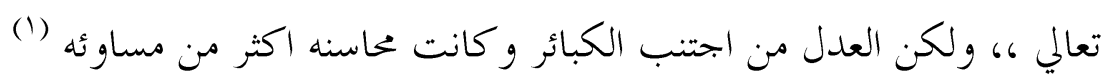

\section{اشـتراط الأئمة للعدالة في الرواية ونية}

热

المعنيون هذا العلم وإن اختلفت طرائقهم و مناهجهم في تعداد الصفات التي في الراوي الذي يقبل خبره،إلا أهم يتفقون على شرط إنى العدالة

$\Sigma \cdot \varepsilon$ وقد فصًّ الإمام الشافعي هذه الصفات في كتابه الرسالة قال : لا تقوم الحجة بخبر الخاصة حتى يجمع أموراً منها:-

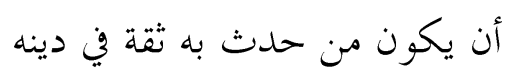
معروفاً بالصدق في من حديثة

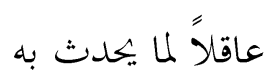
عالماً .بما يجيل معاني الحمديث من به به اللفظ. أن يكون ممن يؤدي الحديث بحروفه

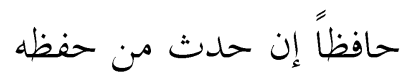
حافظاً لكتابه إن حدث إن من كن حنابه إذا شارك أهل الحفظ في الحلديث وافق حديثهم برئاً من أن يكون مدلساً (1) والثقة في الدين هي العدالة 


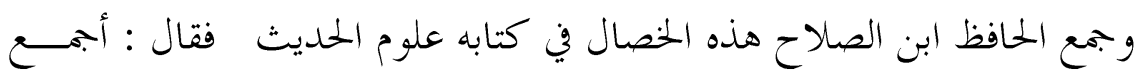

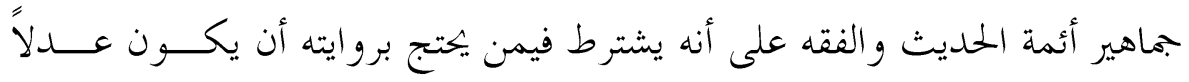

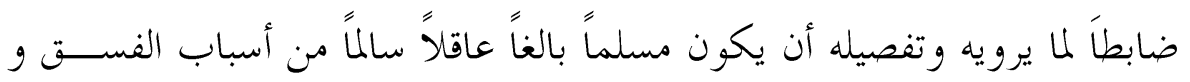

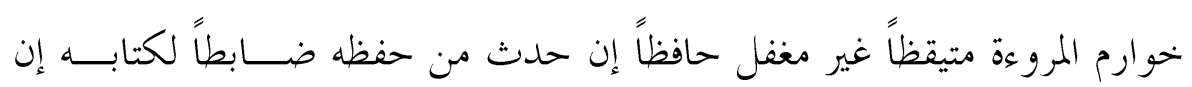

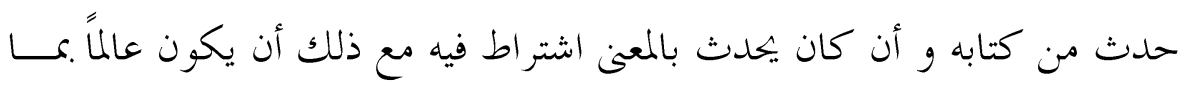

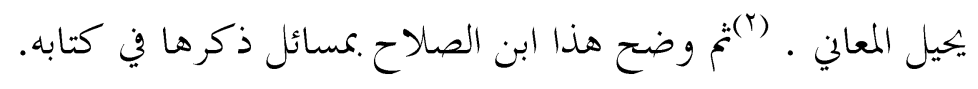

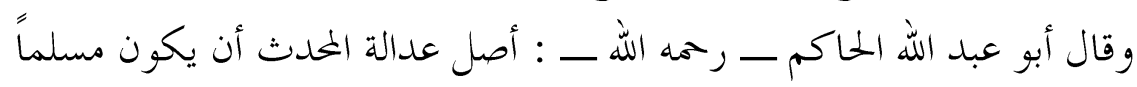

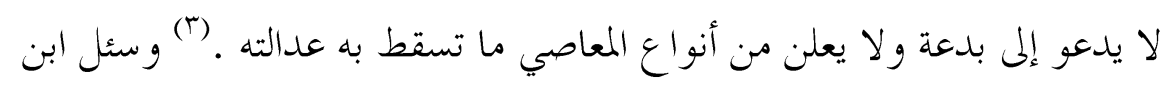

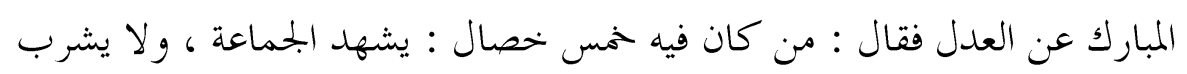

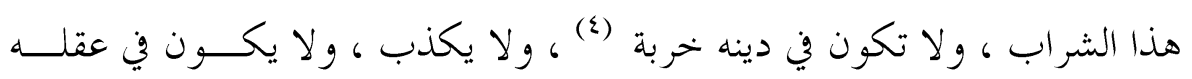

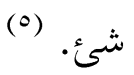
قال يزيد بن هارون : لا يجوز حديث الرجل حتى بتوز شهادته ( الويقدح في

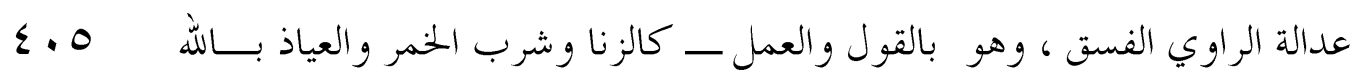

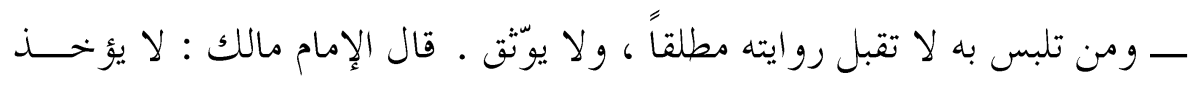

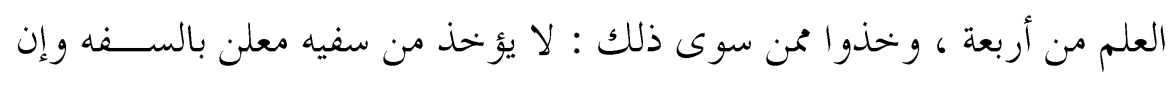

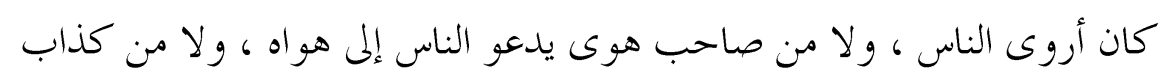

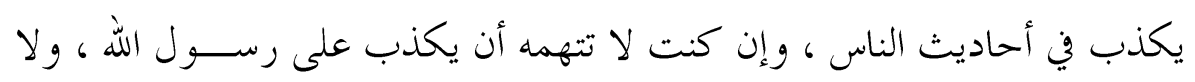

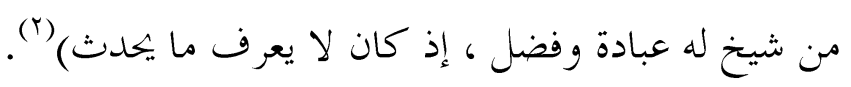

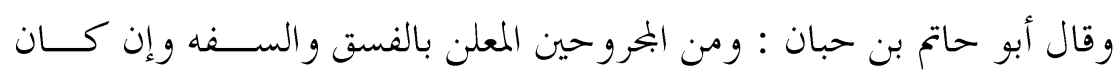

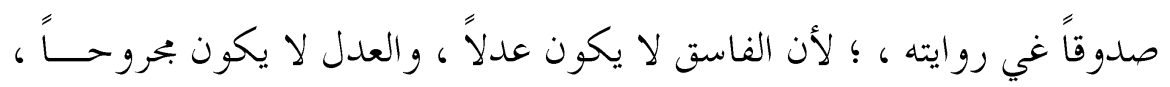

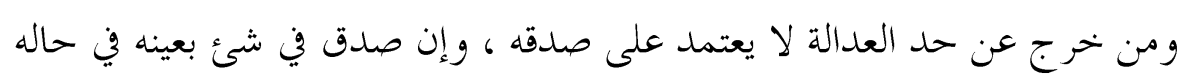

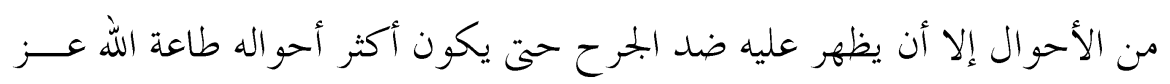

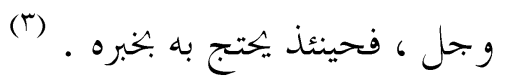


وقال أيضاً : لأن العدل إذا ظهر عليه أكثر أمارات الجرح استحق الترك ، كما

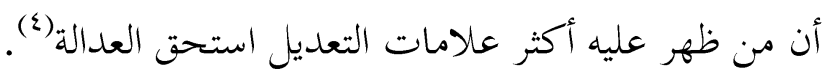

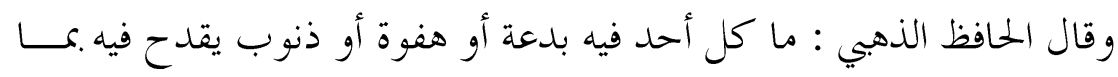

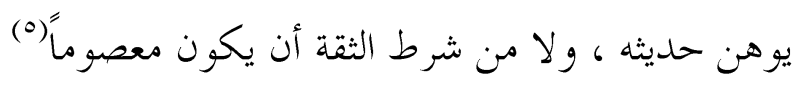

وقال سعيد بن المسيب : ليس من شريف ولا من عالم ولم ولا ذي ذي سلطان إلا وفيه

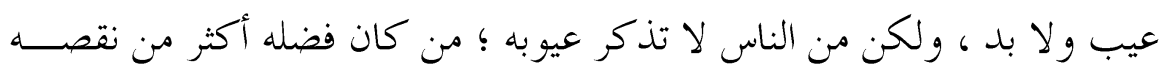

وهب نقصه لفضله . (1)

وقال الإمام الشافعي : لا أعلم أحداً أعطى طاعة الله حتى لم يخلطها بمعصية الله

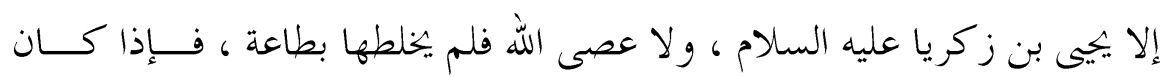

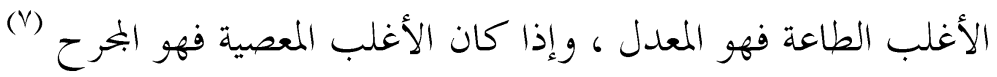

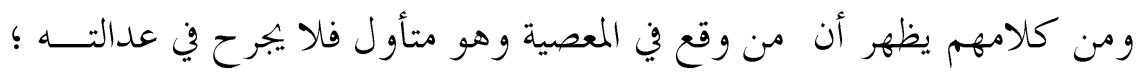

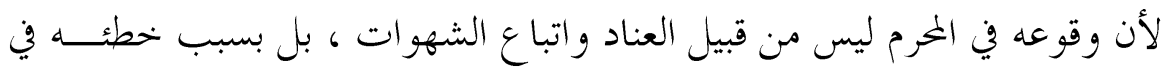

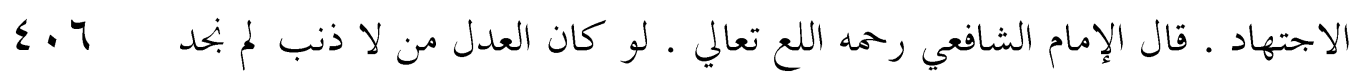

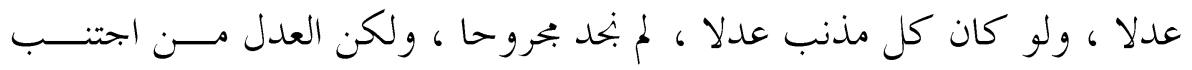

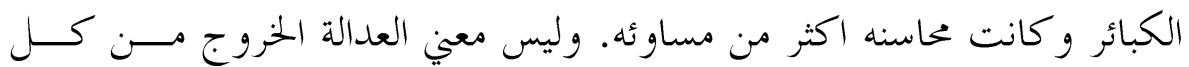

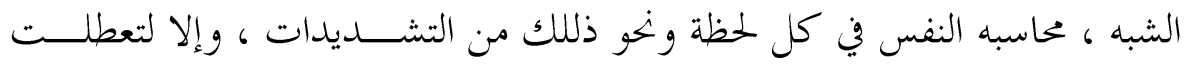

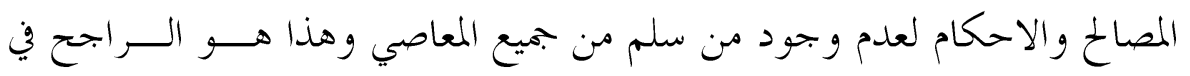
المسألة ويتفق مع ما ذهب إليه العلماء في هذا البحال.

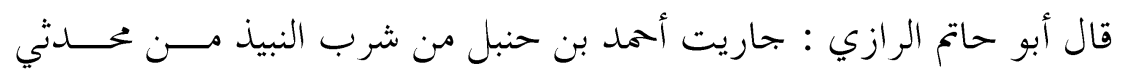

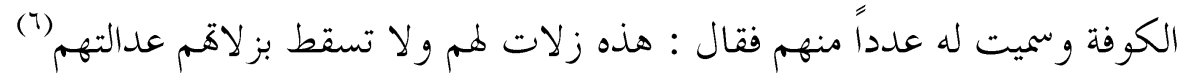

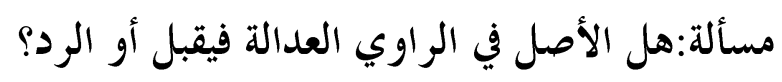

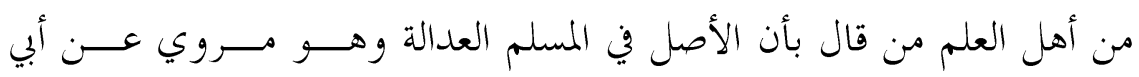
حنيفة(V) و وسيأتي عن ابن حبان و قال به من المنتأخرين ابن الوزير اليمني مستدلين

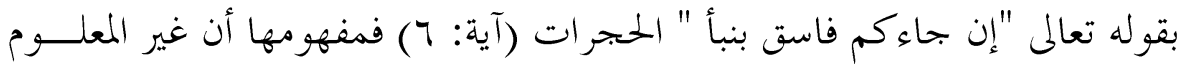


فسقه يقبل خبره واستدلو ابحديث " كل مولود يولد على الفطــــة " وبحــــيث

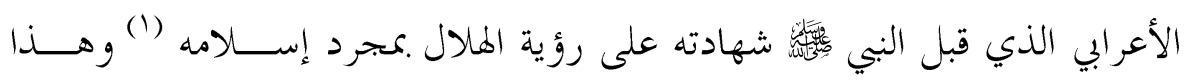

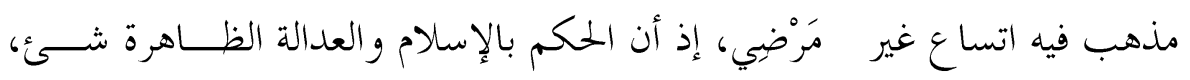

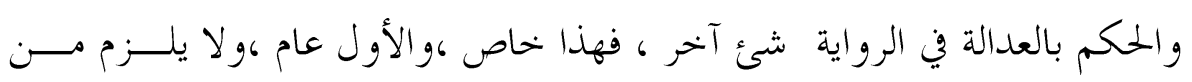
ثبوت العام ثبوت الخناص والقول الثاني : أن الأصل في الراوي الرد حتى تثنبت عدالته، وهـــــ مــــهب المالكية و الشافعية ورو اية عن أحمد

ونقل الصنعاني أدلة هذا القول فمنها قوله تعالى ( وقليل من عبادي الشكور )

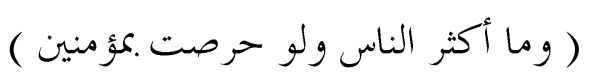

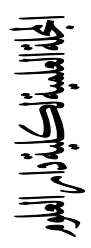
قلت(الصنعاني) : ولا يخفى أنه غير صحيح إذ المر اد من الآيــات أن المــــؤمنين

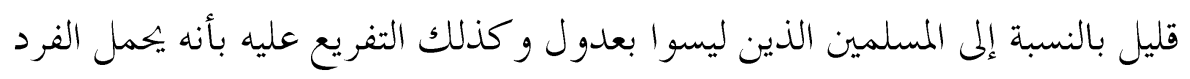

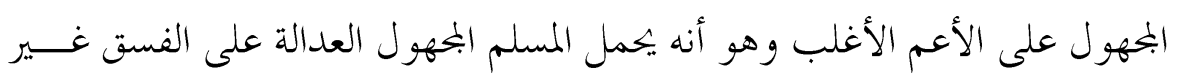

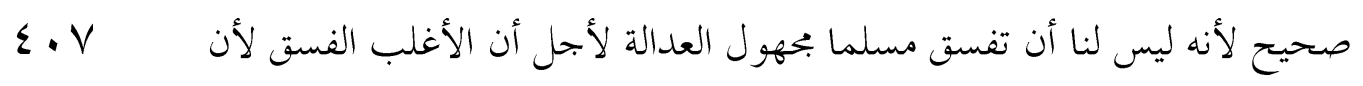

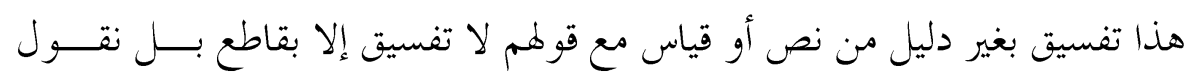

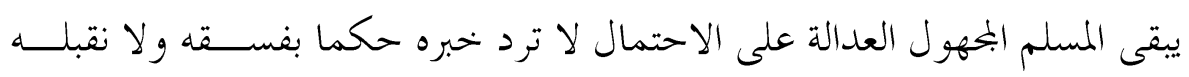

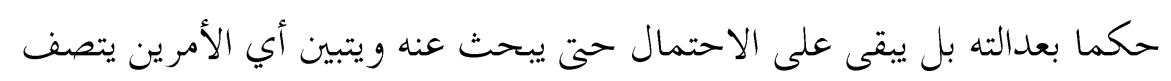

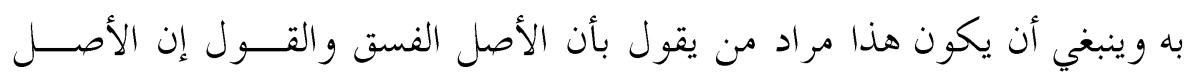

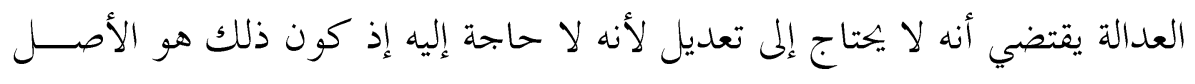

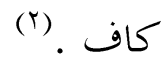

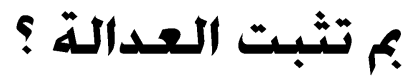

هناك أمور اتفق أهل العلم على أنه تثبت هـا عدالة الـــــاوي وأمـــور اخـــص

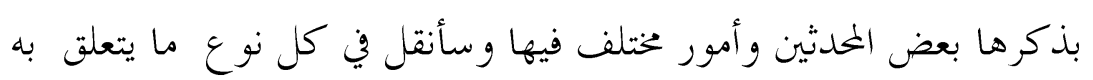

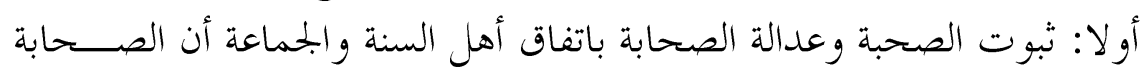

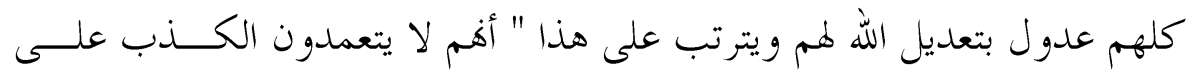


رسول الله لما اتصفوا به من قوة الإيمان، والتزام التقوى، والمروءة، وسمو الأخسـلاق

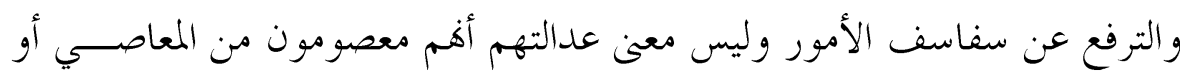

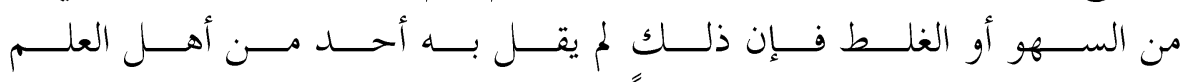

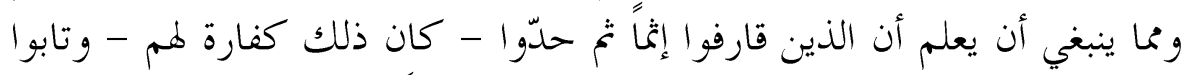

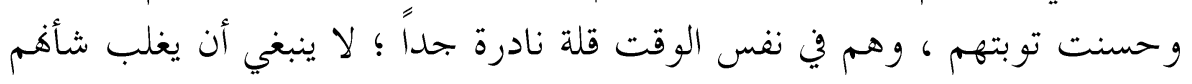

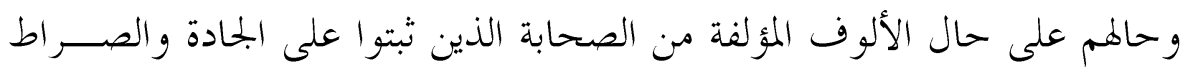

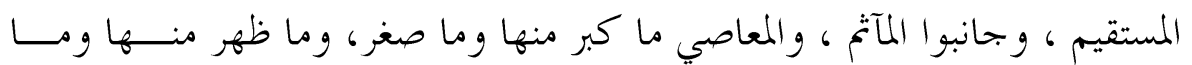

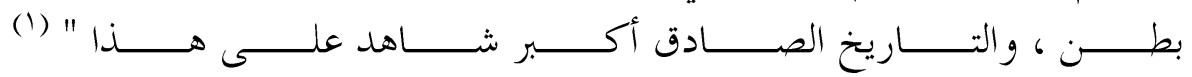

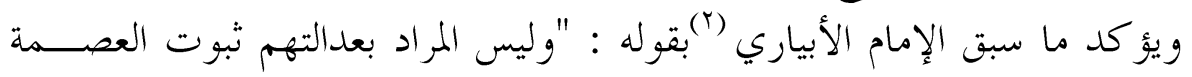

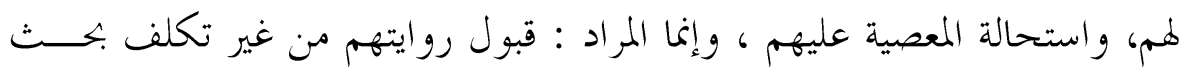

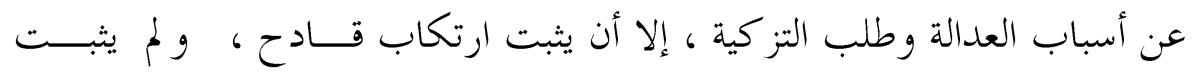

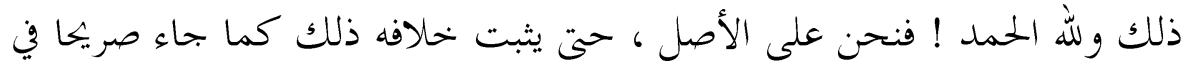

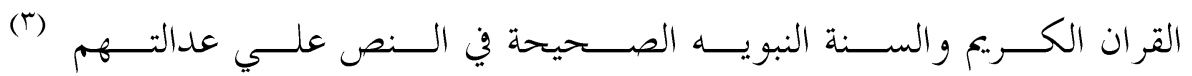

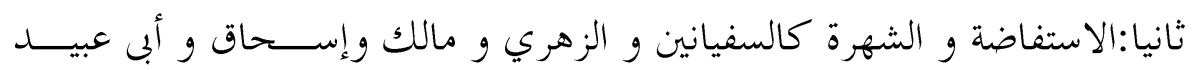

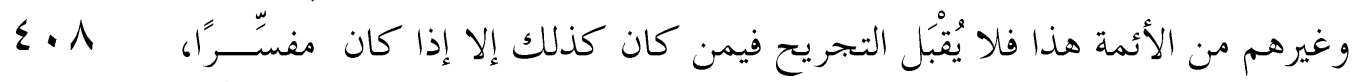

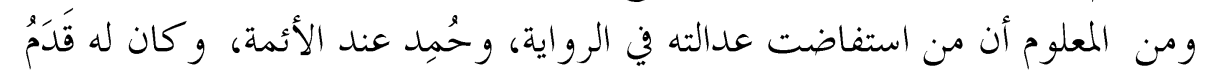

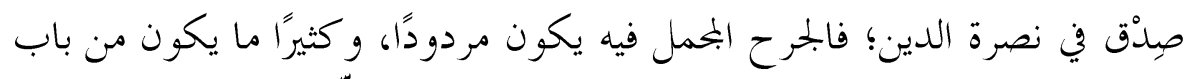

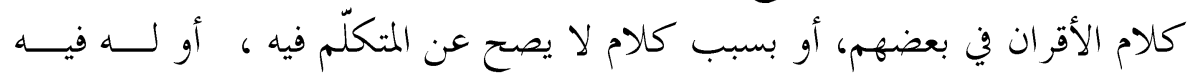

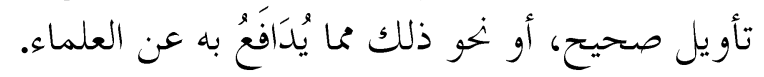

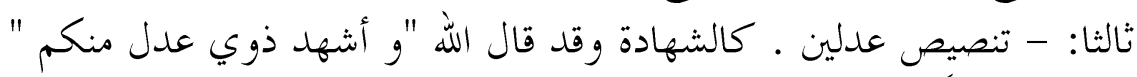

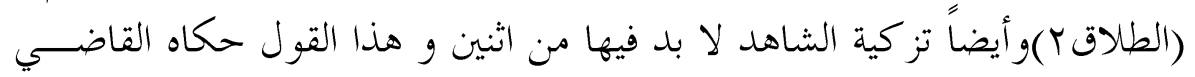

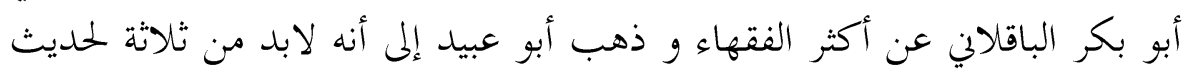

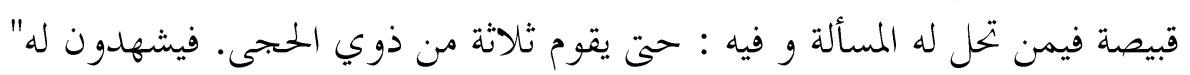

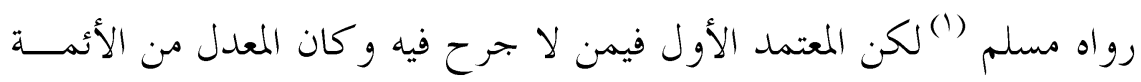
المعتدلين رابعا:- إذا نصٍ على عدالته و احد وهذا القول ذكره الخطيب عــن بعـض العلماءو الختاره وقال ابن الصلاح : وهو الصحيح 
وذكر هؤلاء أن الراوي بخلاف الشاهد لضيق الأمر في الحقوق الخاصة التي هي

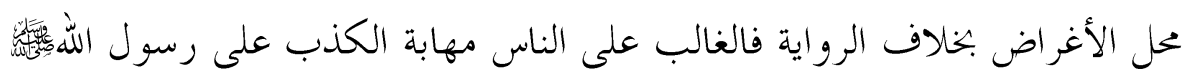

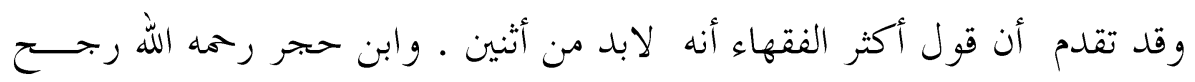

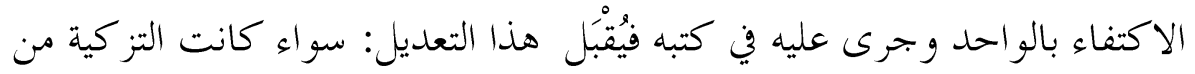

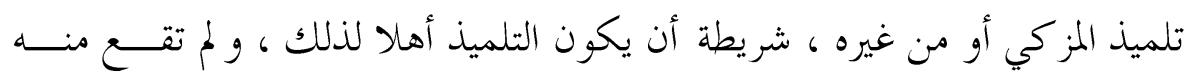

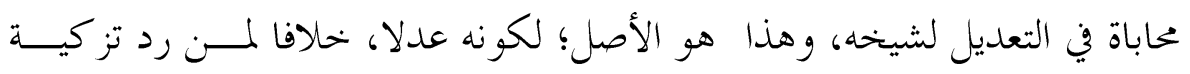

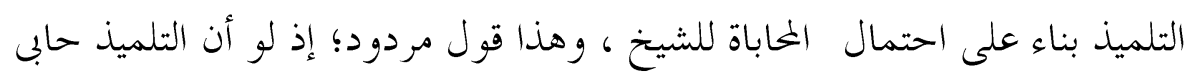

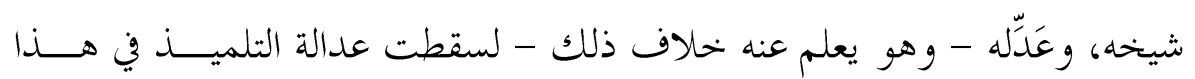

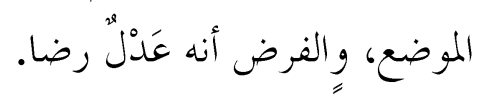

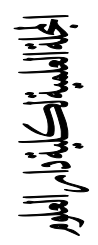

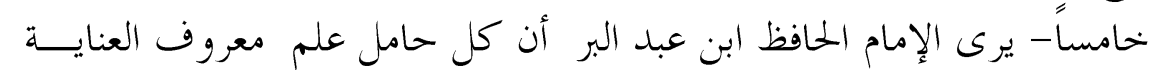

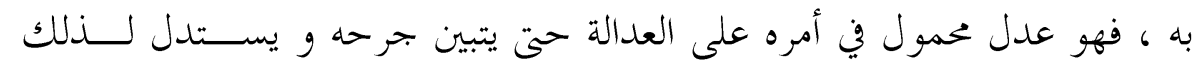

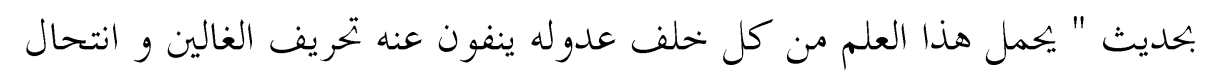

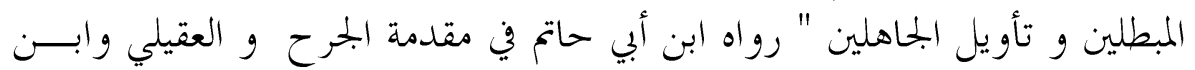

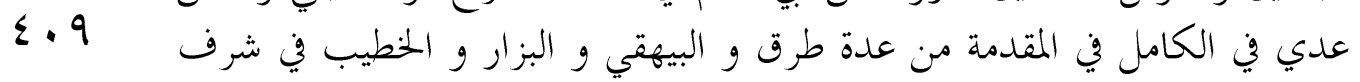

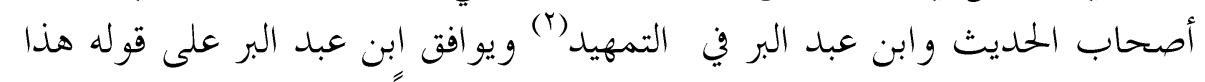

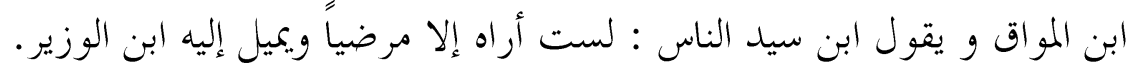

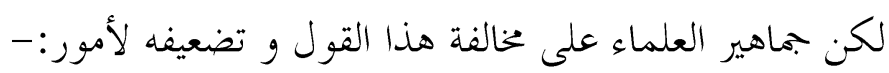

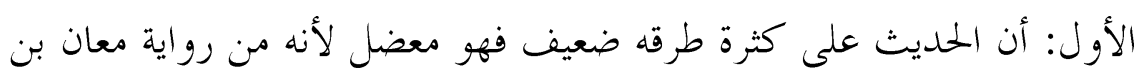

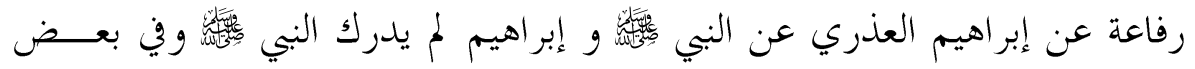

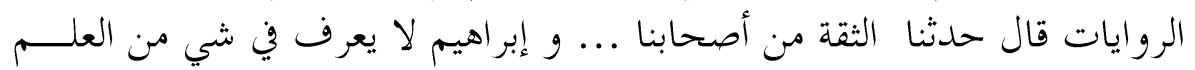

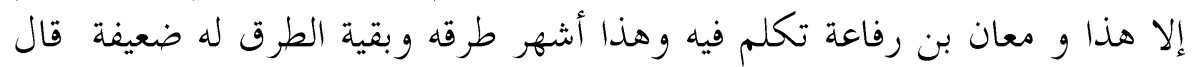

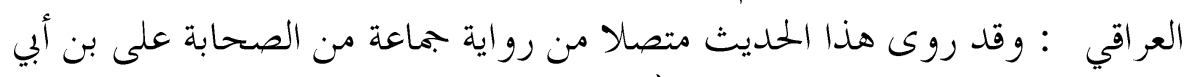

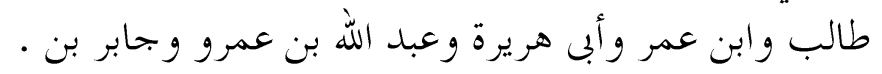

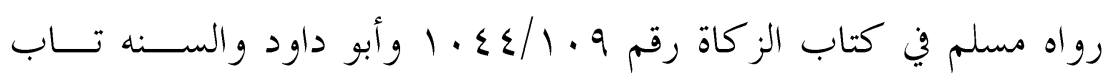

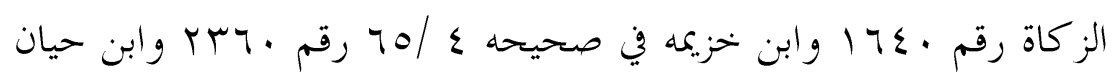

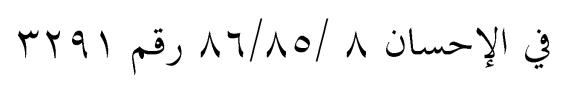




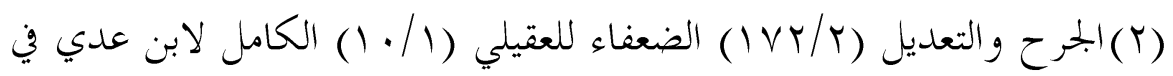

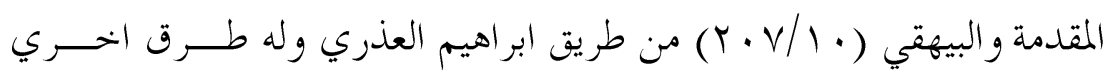

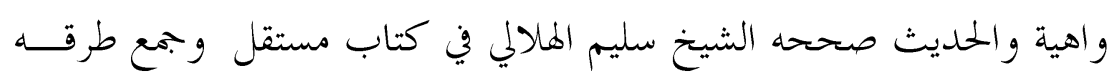

ودرس اسانيده وانتهي الي صحه الحديث في كتابة هذا وهو كتــاب كــبير

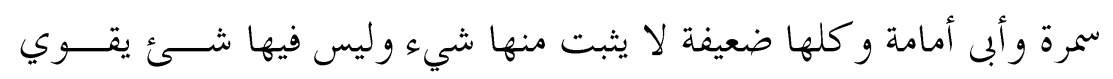

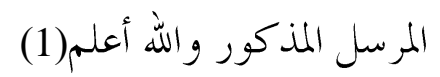

وقال النووي في التقريب : لا يثبت، و قال ابن عبد البر نفسه : أسانيده كلها

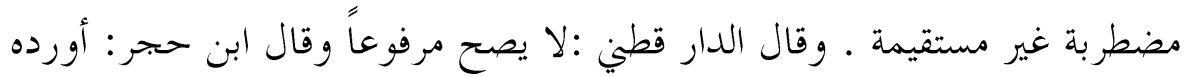

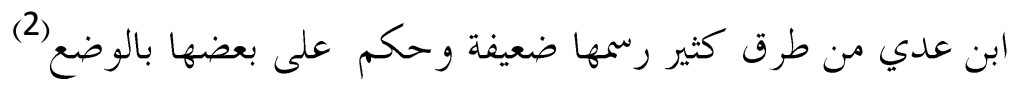

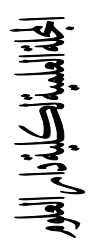

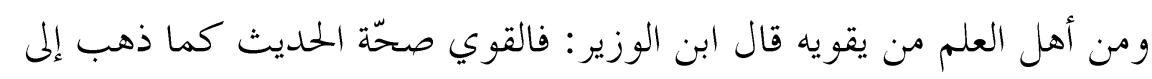

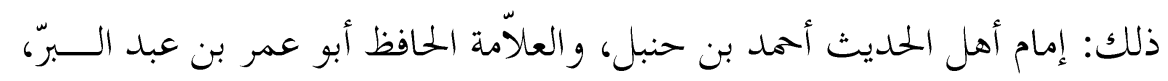
روى تصحيحه عن أحمد بن حنبل غير واحد وابن النّحوي في (البدر المنير) و الزّين

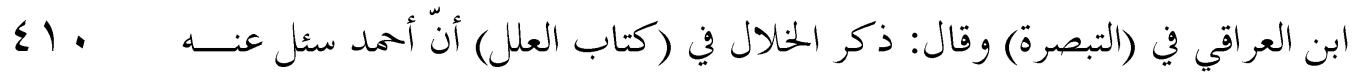

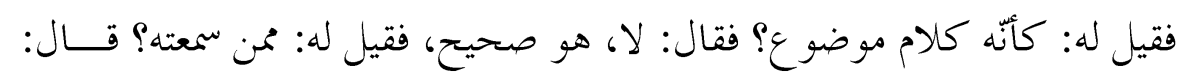

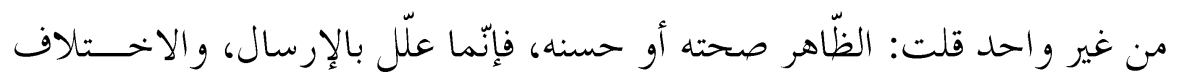

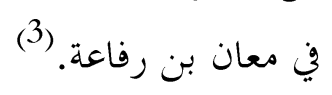

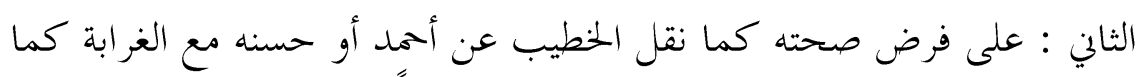

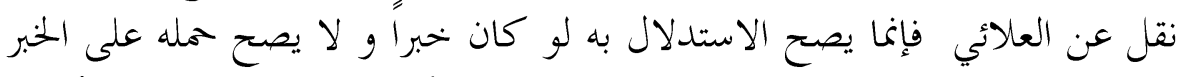

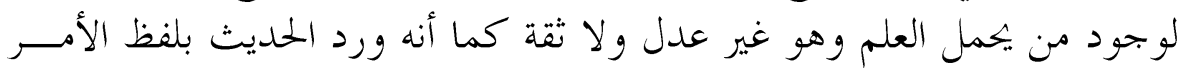

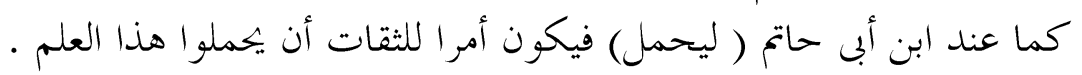

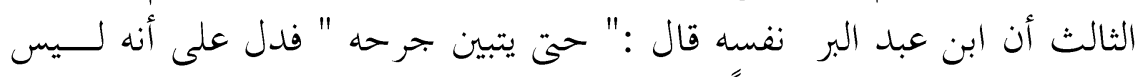

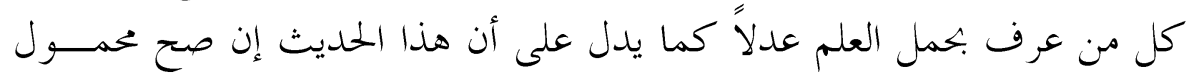
على الأمر تم لو لم ترد رواية ابن أبي حاتم فلا مانع من أن يكون خبر بمعنى الأمر كحديث ليس المؤمن بالطعان ولا اللعان. 
ومن أهل العلم من حمل الحديث على الخبر و أن المقصود به الغالب كــالنووي

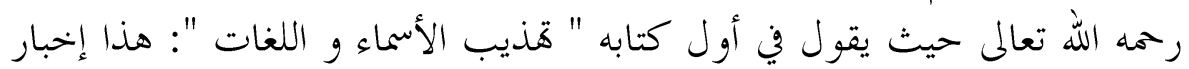

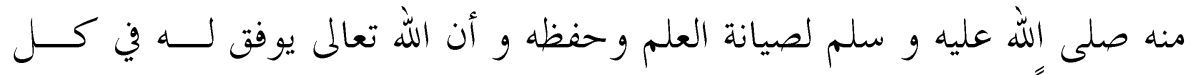

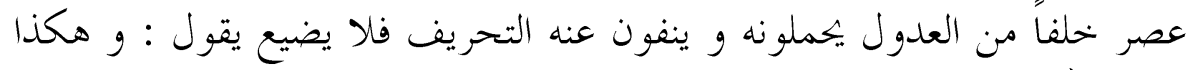

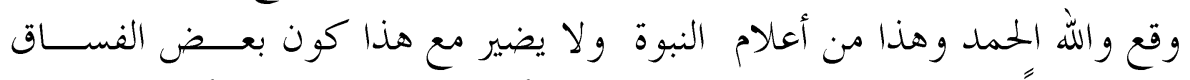

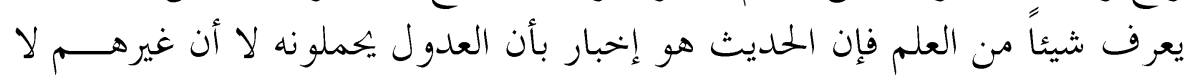

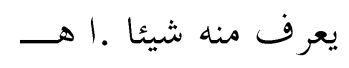

على أنه يمكن أن يقال : أن ما يعرفه الفاسق ليس بعلم حقيقة لعدم عملهم به .

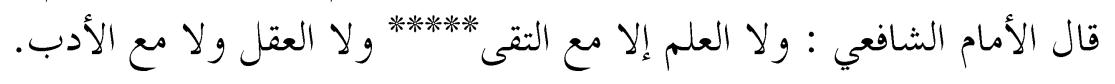

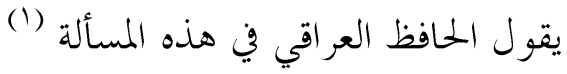

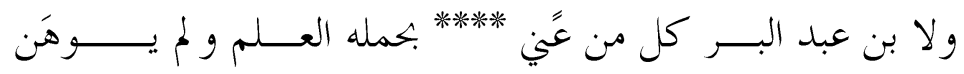

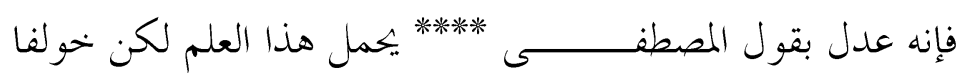

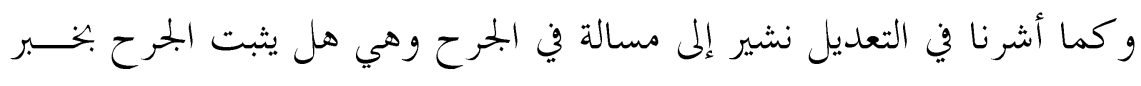

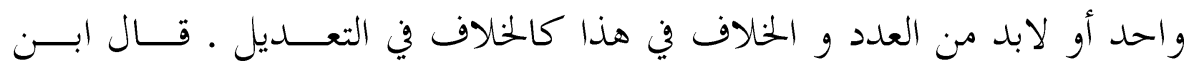
\&1 الصلاح:. الصحيح أن يثبت بجرح بواحد لأن العدد لم يشترط في قبول الخبر فلم يشترط في جرح راويه، وهذا بخلاف الشهادات. وهذا هو المتفق عليه بين العلماء

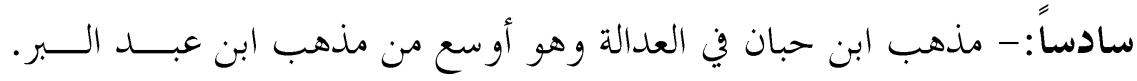

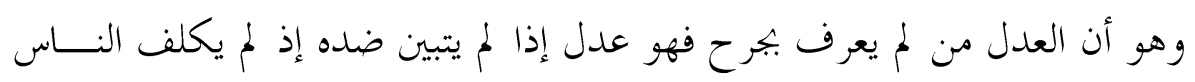

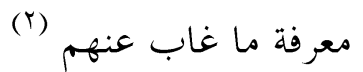
وبذا المذهب وثق ابن جبان و ذكر في كتابة كثيراً من المحاهيل و المســتورين

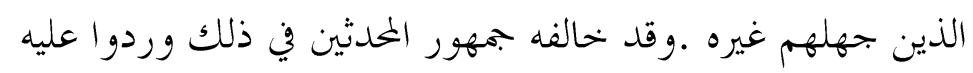

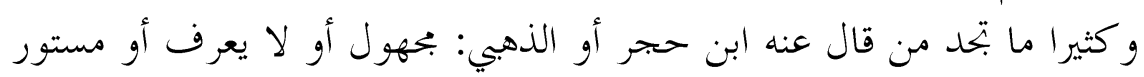

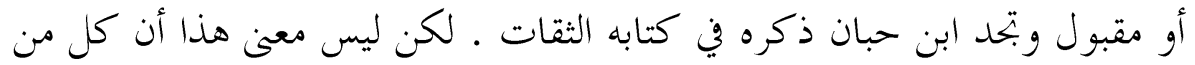

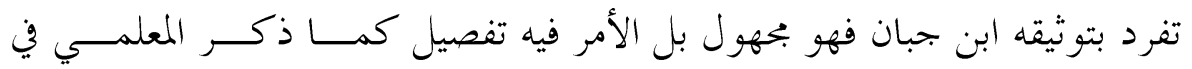

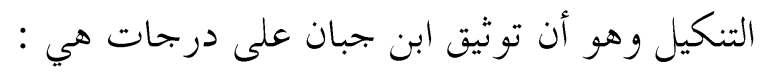


- أن يصرح به كأن يقول : كان متقناً مستقيم الحديث أو نحو ذلك ـ فهـــهـ قال المعلمي لا تقل عن توثيق غيره من الأئمة.

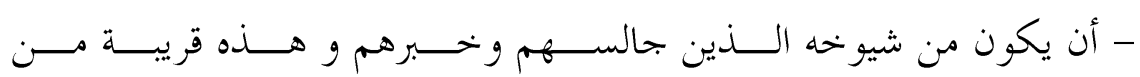
الأولى لئل - أن يكون من المعروفين بكثتــرة الحـــديث بحيــث يعلـــم أن ابــن جبـــان وقف على أحاديث كثيرة له " مقبولة "

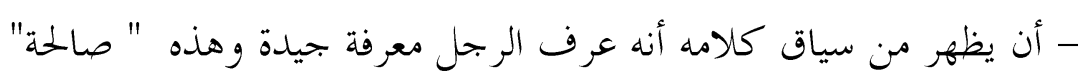

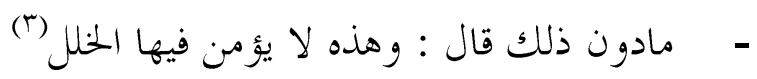
وعلي كل حال فهذا مذهب خاص بابن حبان نازعه فيه البعض ووافقه البعض

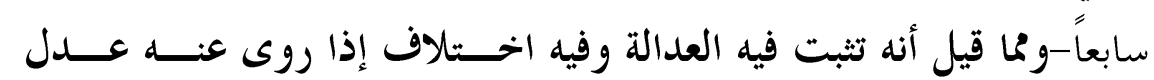

$$
\text { وسكت عنه فهذا فيه ثلاثة أقوال : }
$$

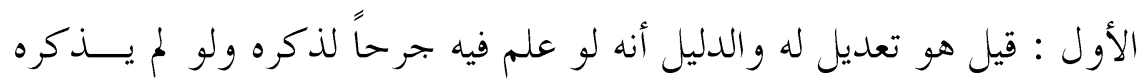

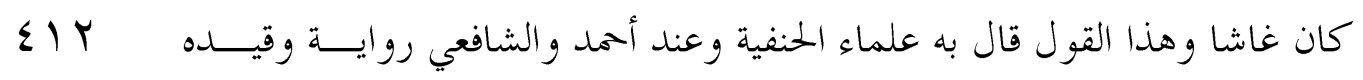
بعضهم بالقرون الثلاثة. وهذا القول مرجوح فقد رده الخطيب ورد على استدلاله وقال : إن الــــاوي

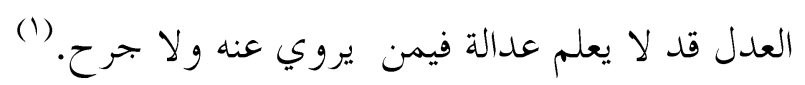

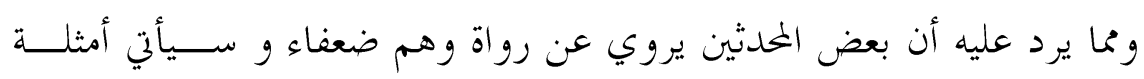

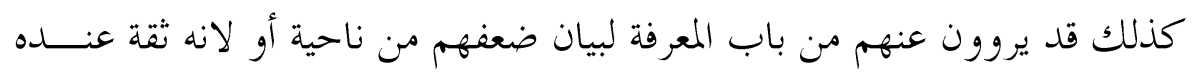

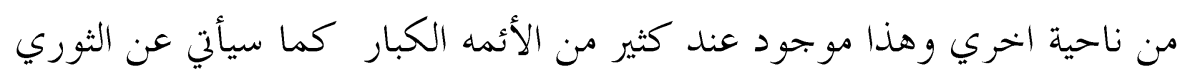

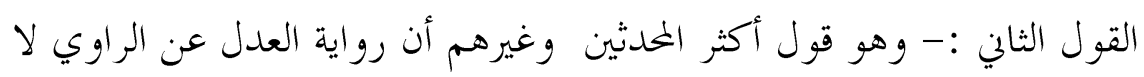

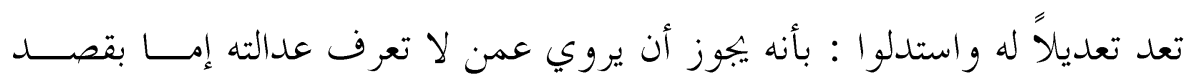

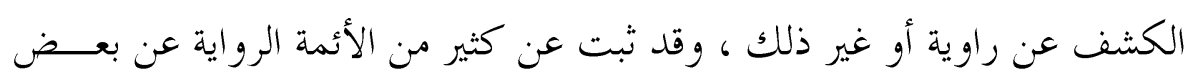

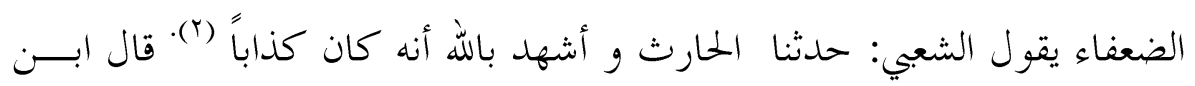

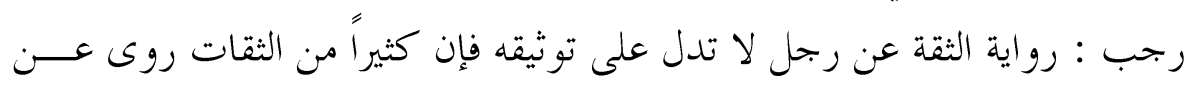


الضعفاء كسفيان الثوري و شعبة وغيرهما و كان شعبة يقول :- لو لم أحســثـم

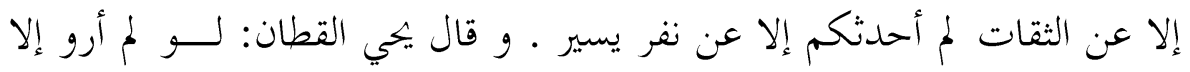
عمن أرضى ما رويت عن خمسة أو نحو ذلك و ذكر العقيلي بإسناد له عن الثوري

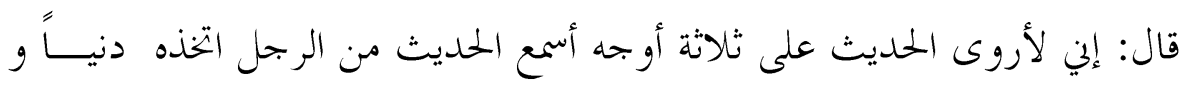

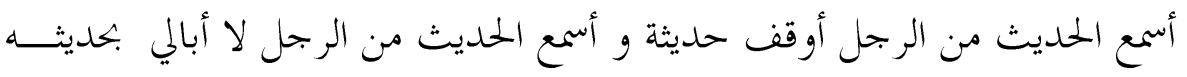

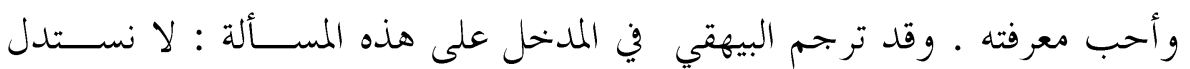
كعرفة من حدثنا على صدق من فوقه وإذا كان العدل تفرد عنه فكثيرون يطلقون على من لمُ يرو عنه إلا راو واحس واحد و لم تعرف حاله "بجهول العين " فهو عرفت ذاته و ذكر اسمه .. لكن لكونه مقلاً

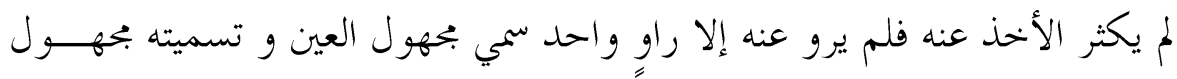

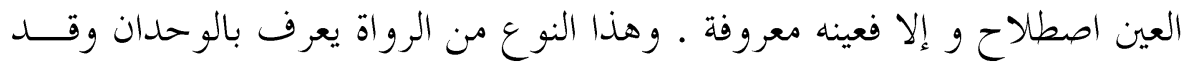

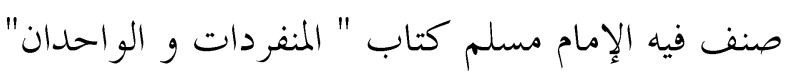

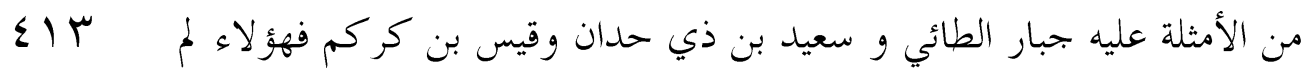

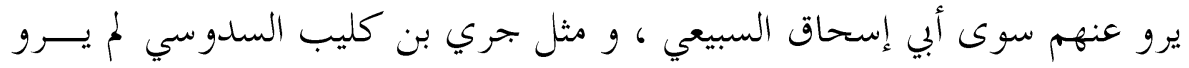

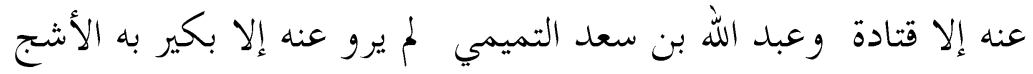

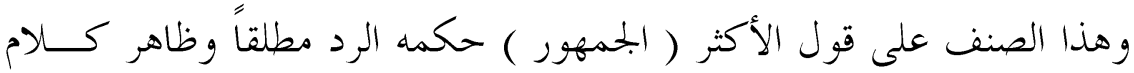
ابن كثير الاتفاق عليه ، وقد حكي الإجماع في الرد السبكي وقال ابن المواق : لا

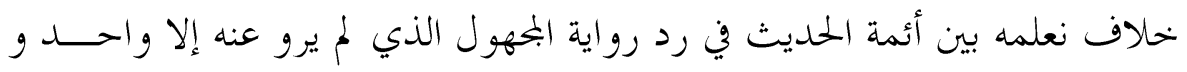

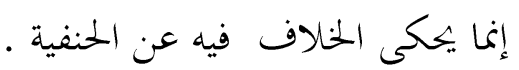

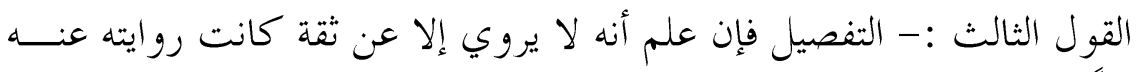

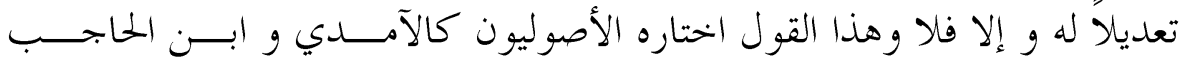

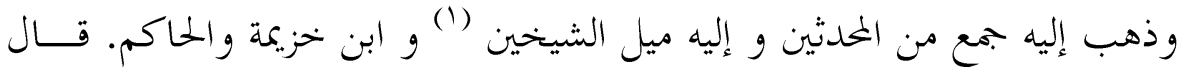

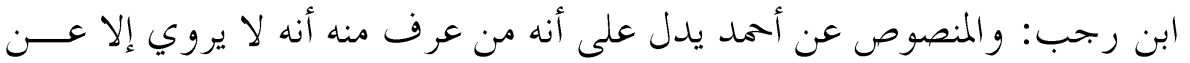

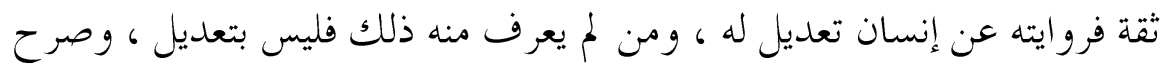

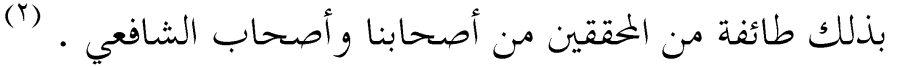


ولنتأمل هذا النص : قال يعقوب بن أبي شيبة : قلت ليحيى بن معــين : مــتى

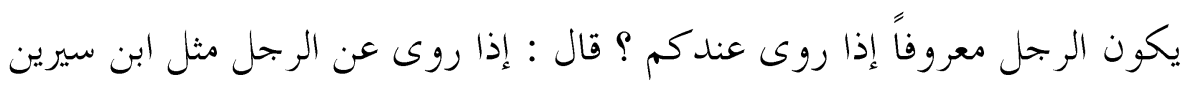

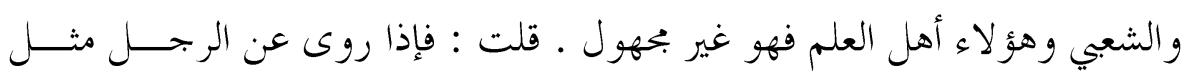

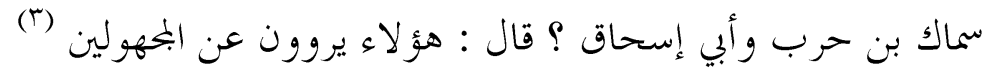

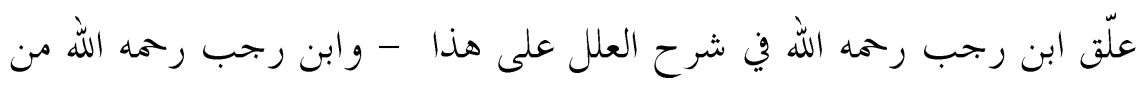

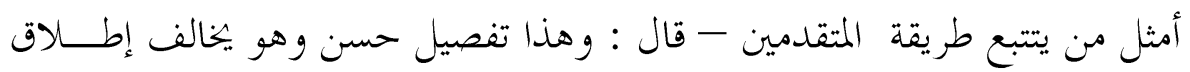

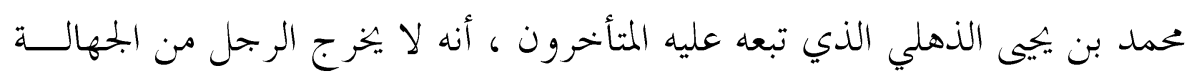

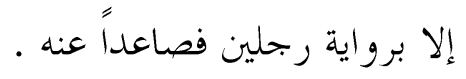

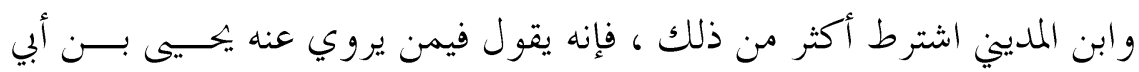

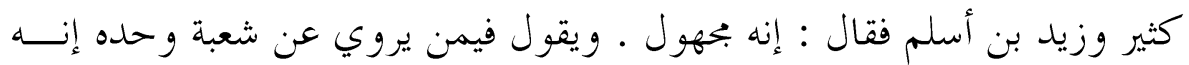

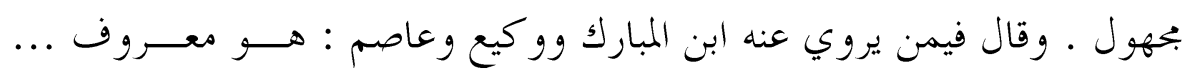

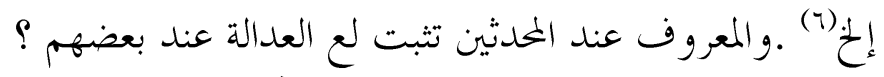
ย)ร

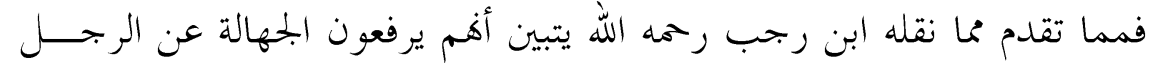

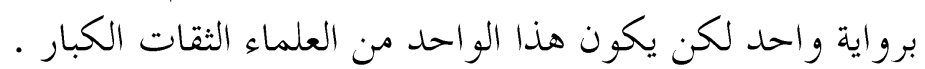

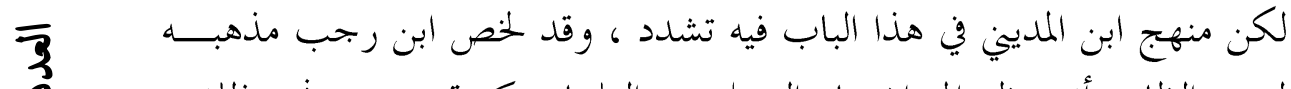

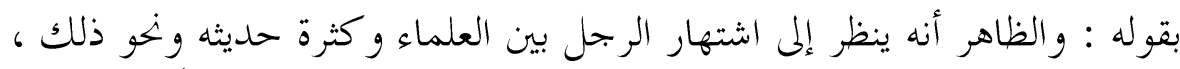

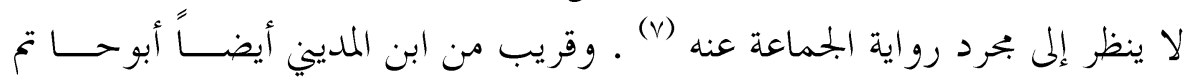

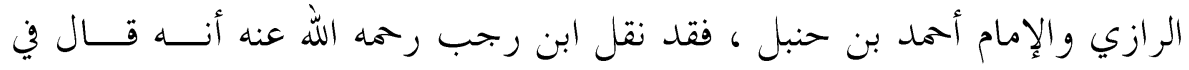

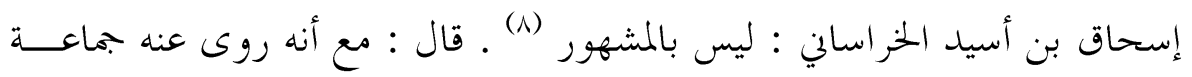

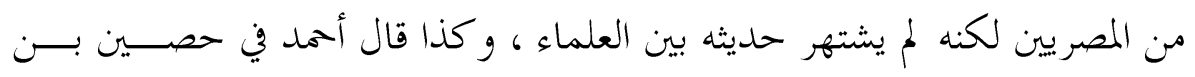

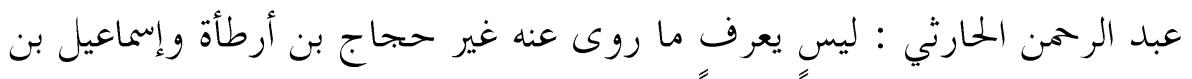

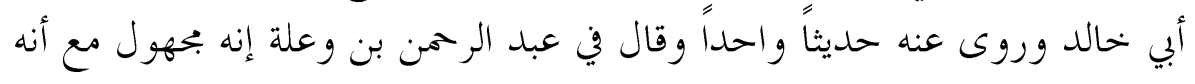

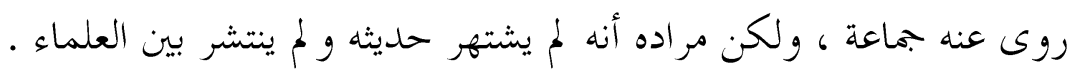

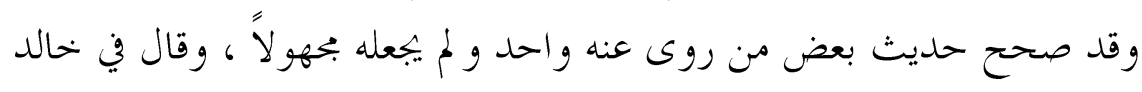

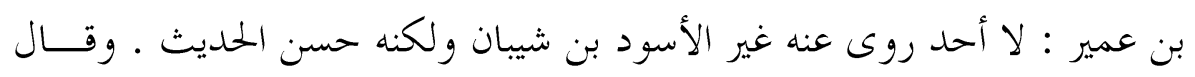

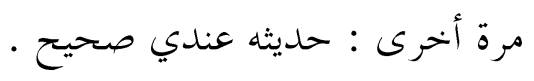


كذا قرر ابن رجب مذهب أبي حاتم وأحمد ثم علق على ذلك بقوله : وظـــاهر

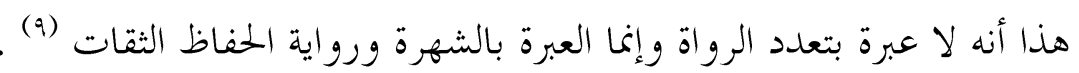

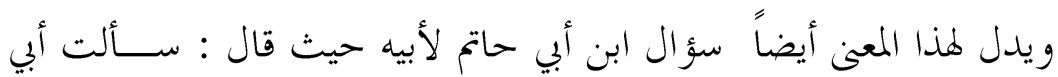

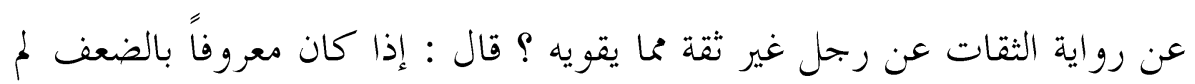

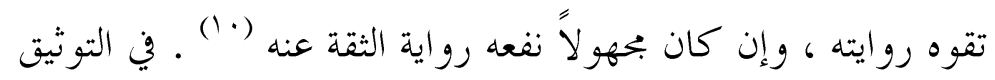

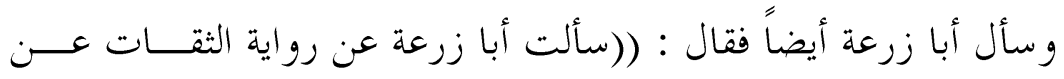

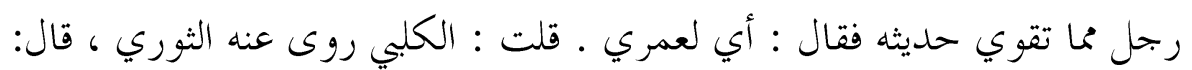

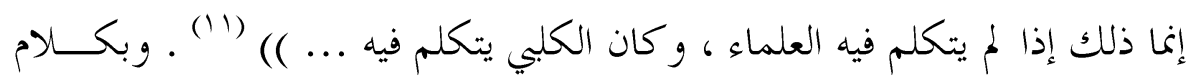
قادح فاعتراض ابن أبي حاتم بالثوري يدل على أن الثقة الذي ترفع روايته الجهالة

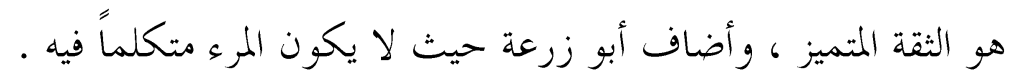
فالخلاصة مما سبق مما نقلناه أن الراوي ترتفع عنه الجهالة إذا :

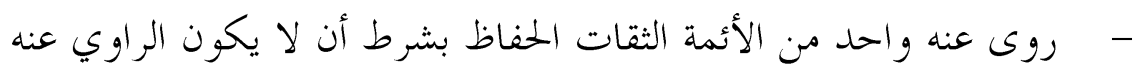

$\sum 10$ يروي عن المجهولين كما دل عليه كلام يجيى بن معين .

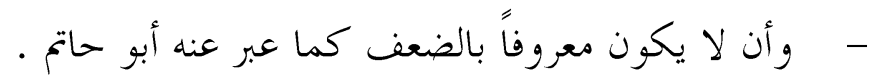

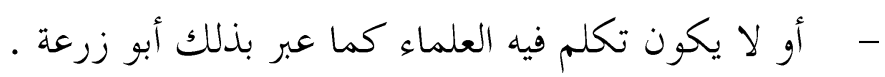

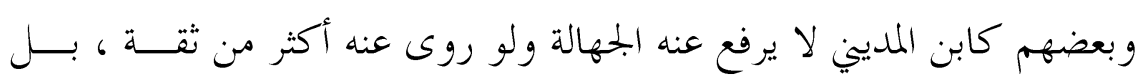

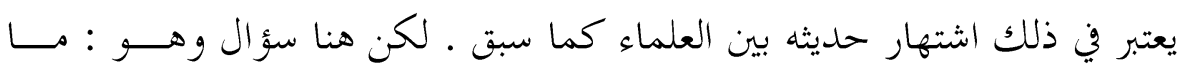

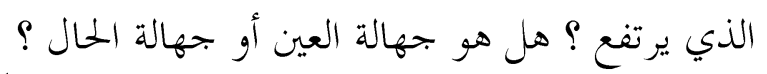

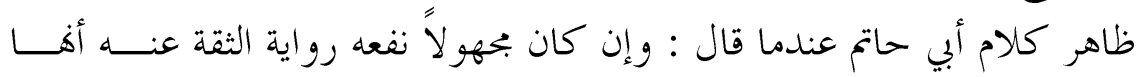

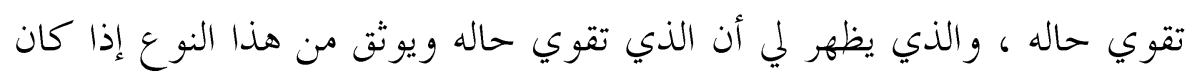

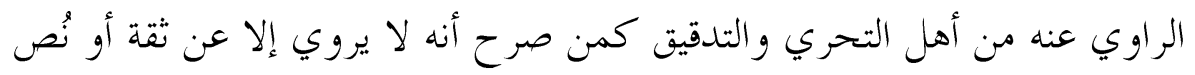

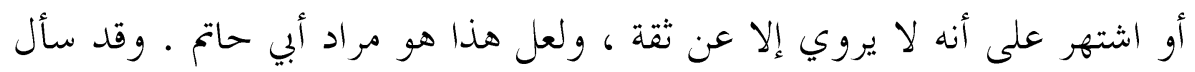

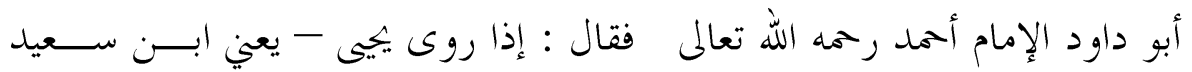

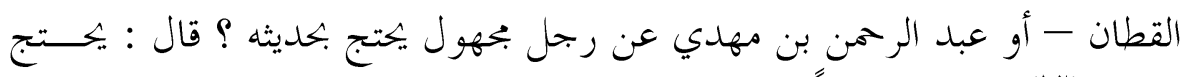

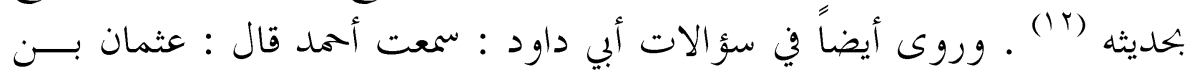




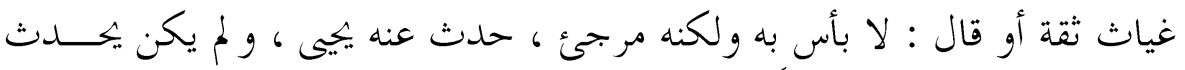

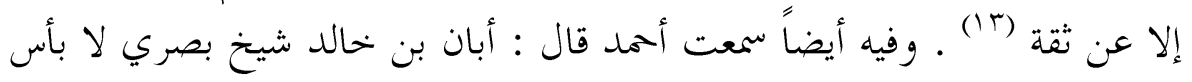

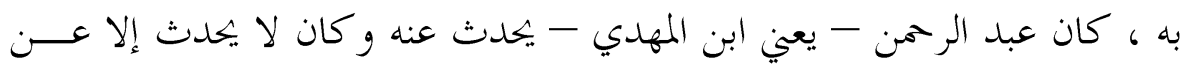
نقة

قال ابن رجب : و المنصوص عن أحمد يدل على أنه من عرف منه أنه لا يروي

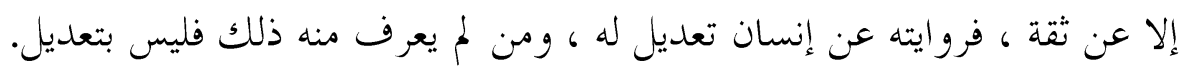

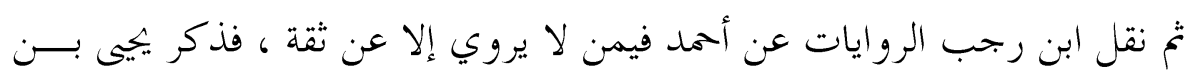

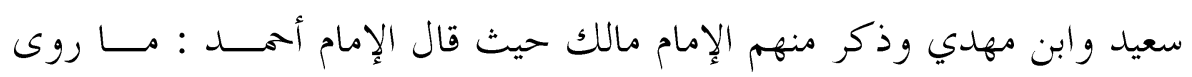

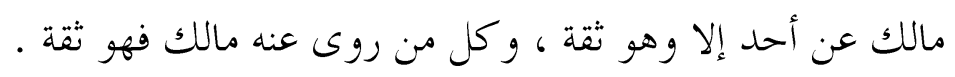

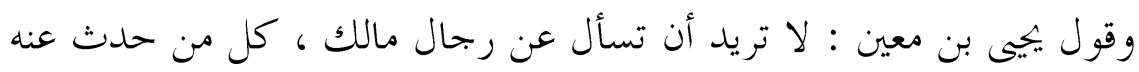

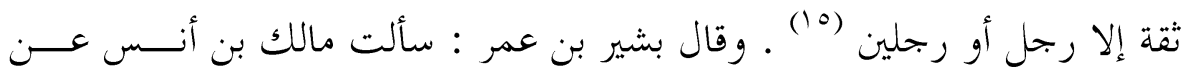

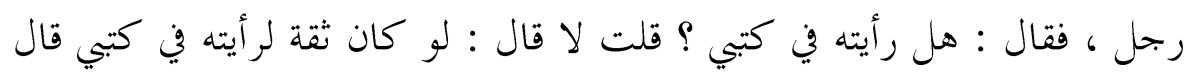

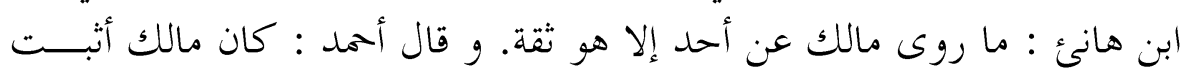

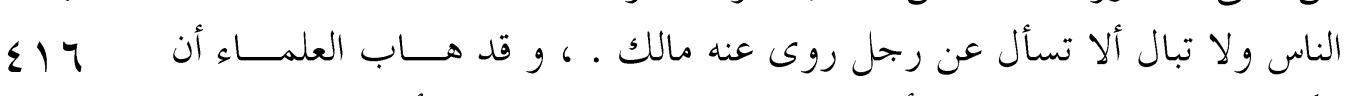

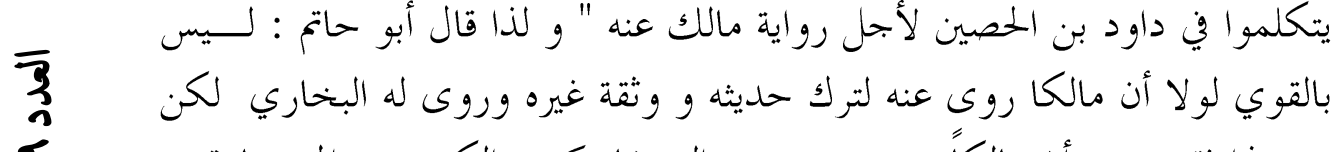

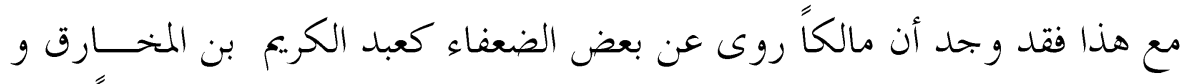

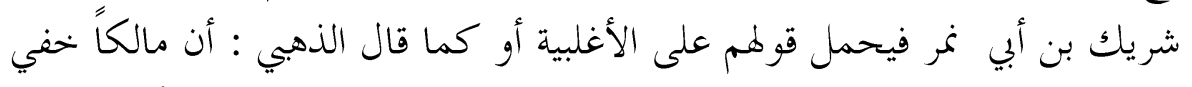

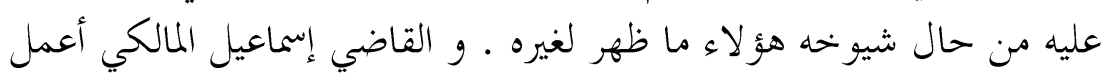

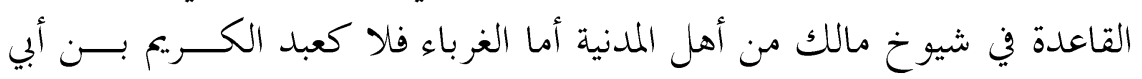
المخارق وغيره وممن كان لا يروي إلا عن ثقة إلا في النادر غير ما سبق : الإمام أحمد ، و وبقي

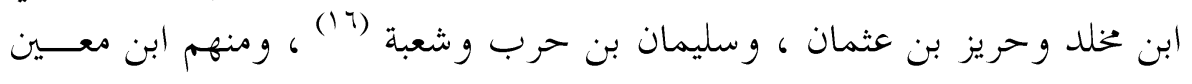

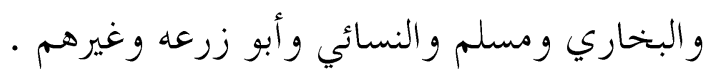

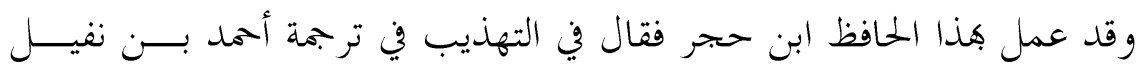

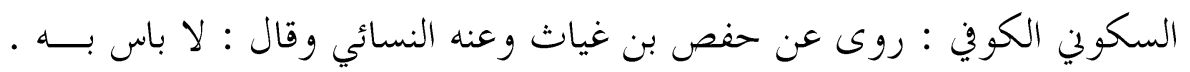

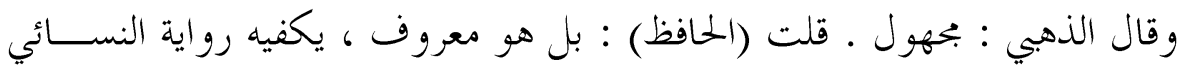




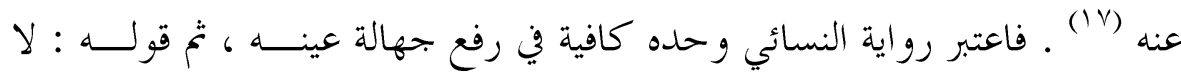

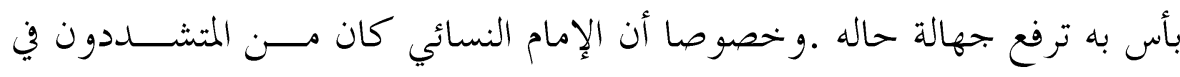
قبول الرواية

وقال في ترجمة أحمد بن يهيى الحراني : وقال الذهبي في الطبقات : أحمد بن بيى فيى بن محمد لا يعرف ، قلت : بل يكفي في رفع جهالة عينه رواية النسائي عنه ، و وين

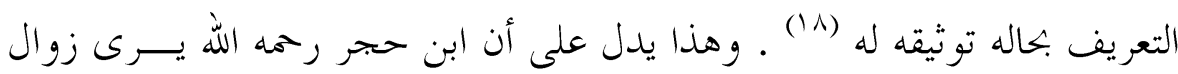

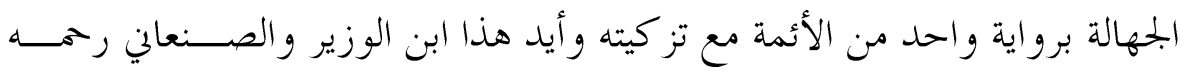

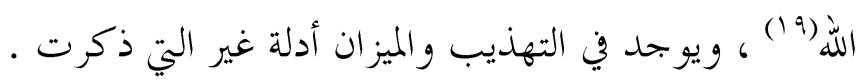

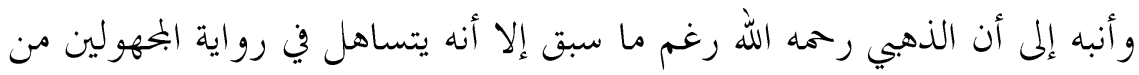

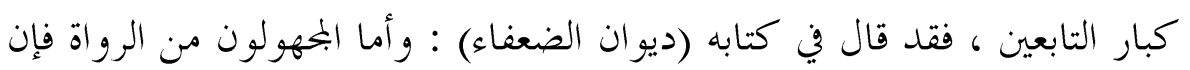

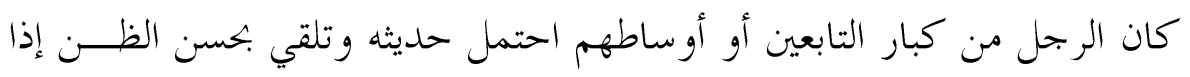

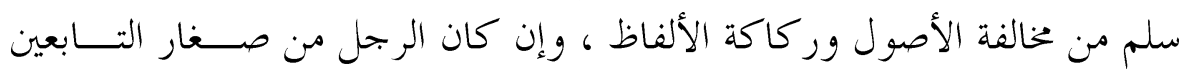

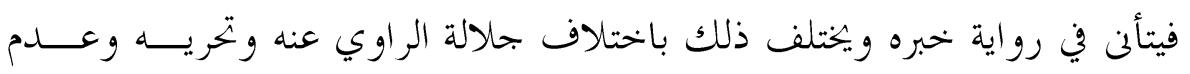

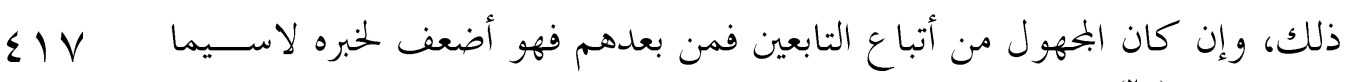

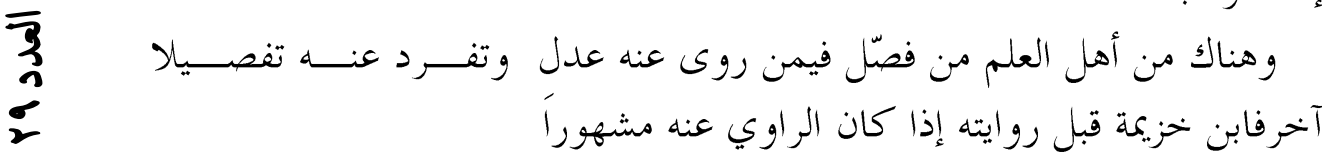

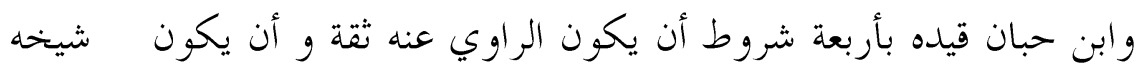

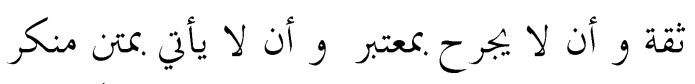

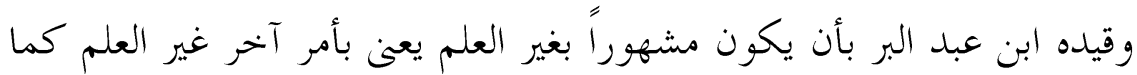

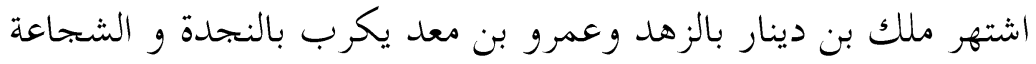

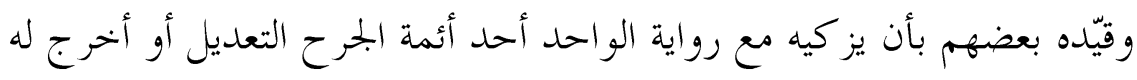

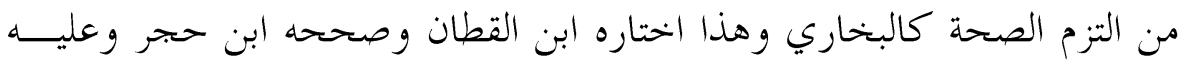

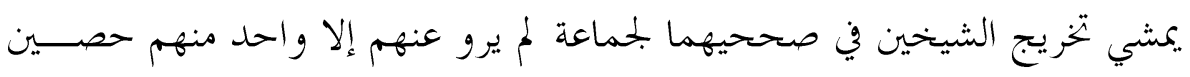

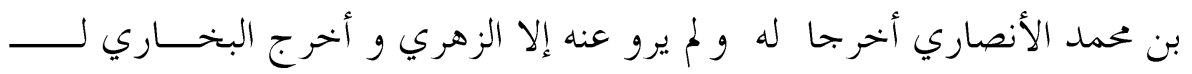

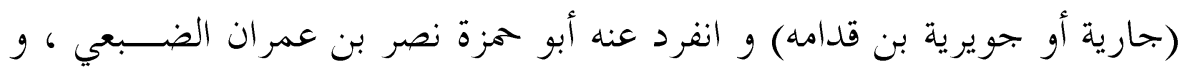

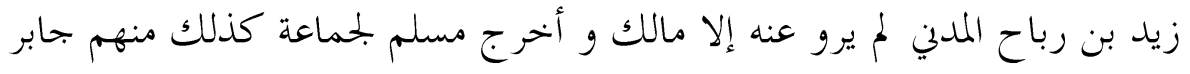


بن إسماعيل الحضرمي لم يرو عنه إلا ابن وهب و خباب المدني تفرد عنه عامر بن

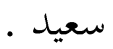

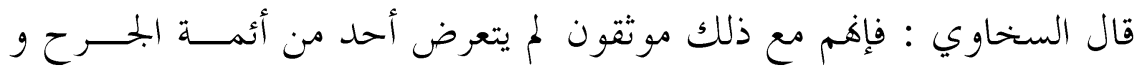

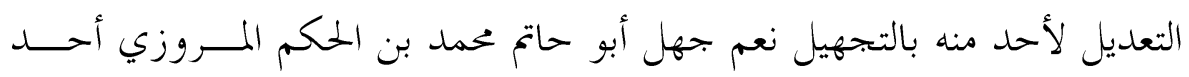

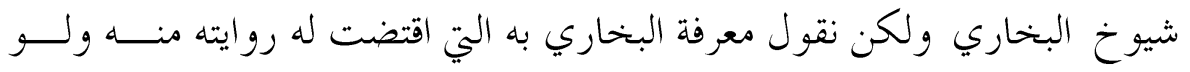

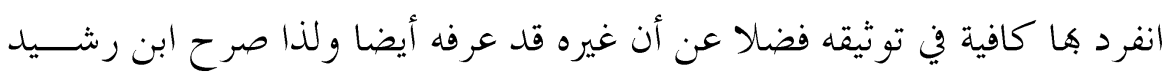

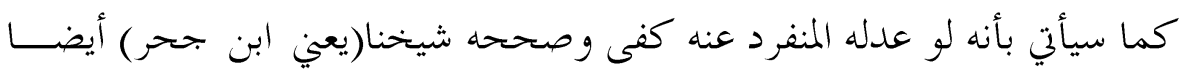

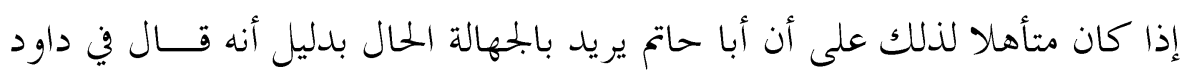

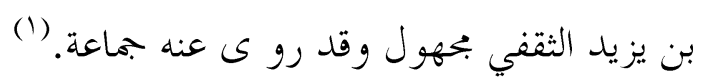

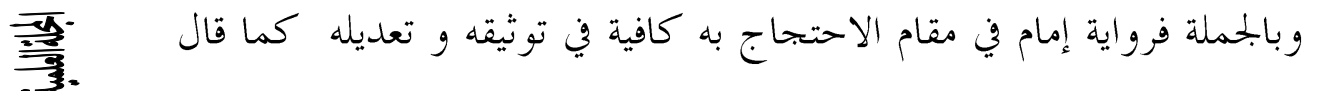

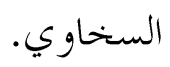

وهناك من قيده .ما سوى الصحابة لأن الصحابة كلهم عدول ونســب هــــا

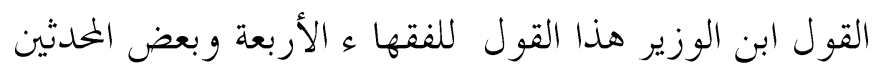

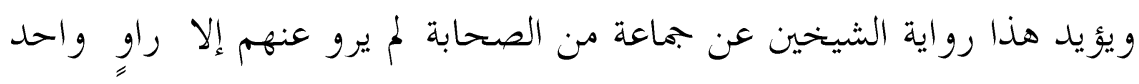

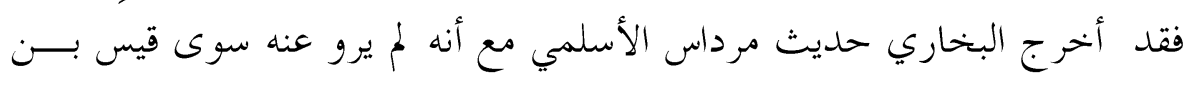

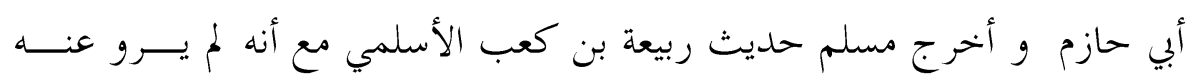

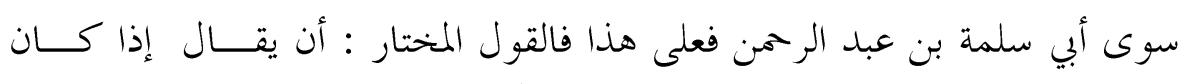

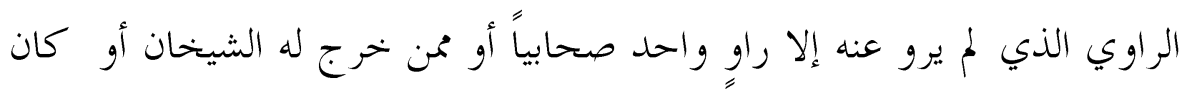

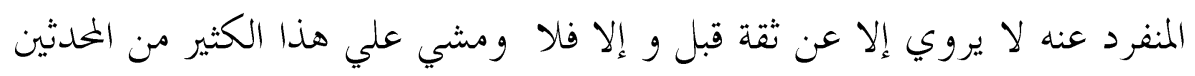

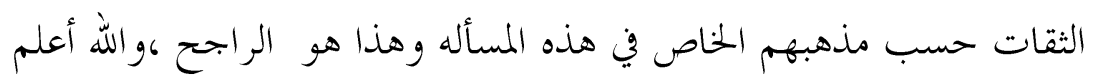

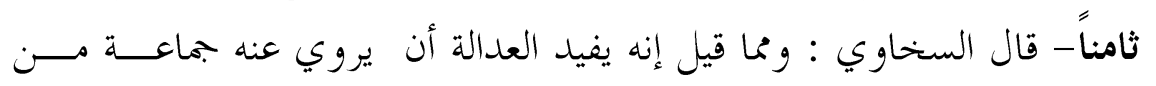

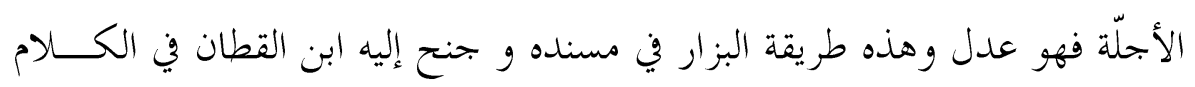

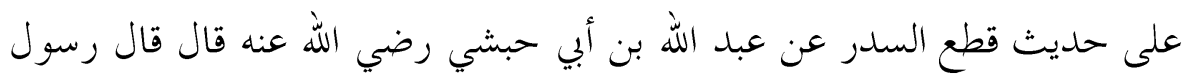

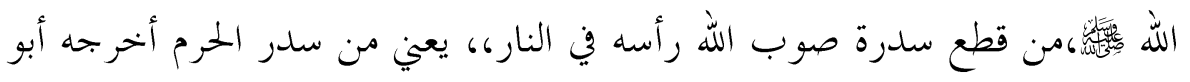




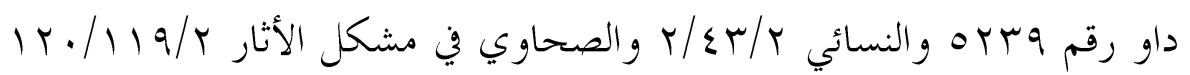
وغيرهم وهو حديث صحيح صححه الالباني حديث رقم ع الج السلسه الصحيحة من كتابه الوهم و الإيهام ونقل هذا عنه الذهبي في ترجمة مالك مالك بن الخير ثم قال :

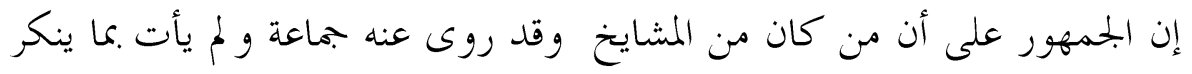

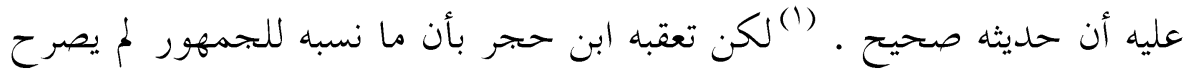

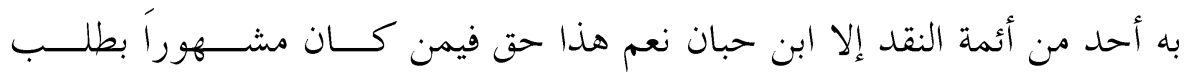

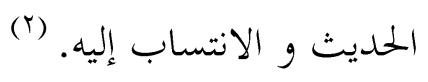

أقول : نسبة توثيق البحاهيل لابن القطان غير مطردة قال الشيخ مقبل الوادعي:

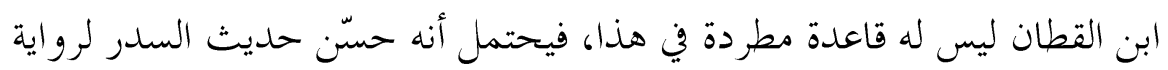

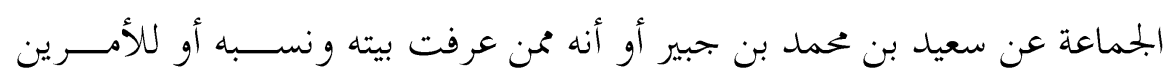
هميعاً. وهذا نص كلامه: (...وأما ابن عمه سعيد بن محمد بن جبير بن مطعــم فــلا

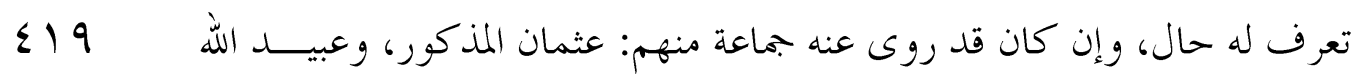

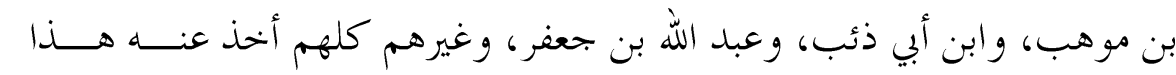

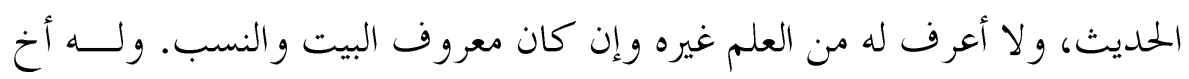

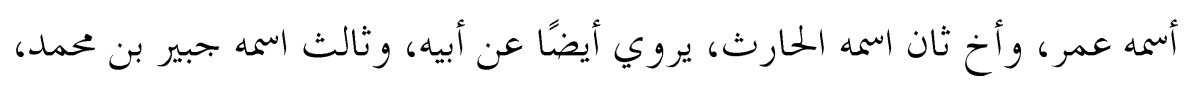

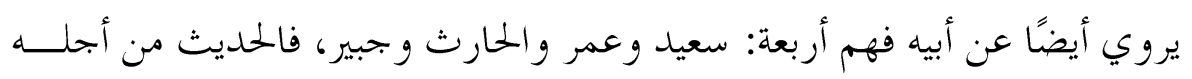

أقول : ومما يؤيد ذلك أن ابن القطان يجهل كل من لم ينص عليه إمام عاصره

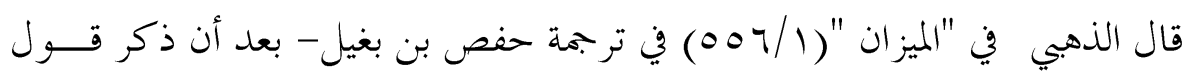

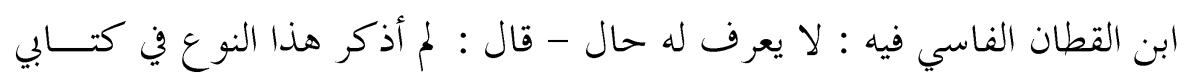

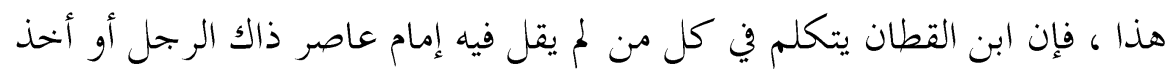

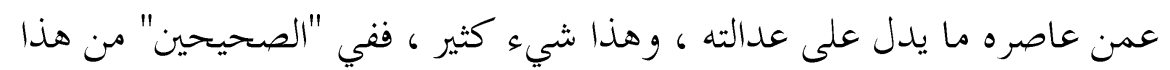

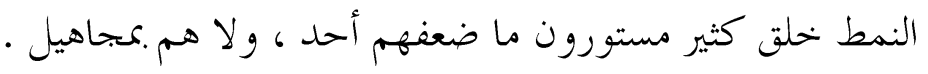


والقول بأن رواية جماعة من العدول عن الراوي تعتبر تعديلا له إذا لم يأتي بمنكر

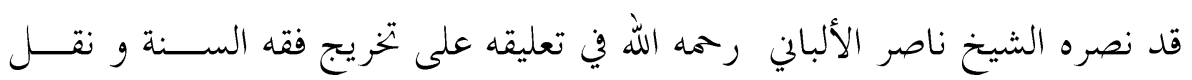

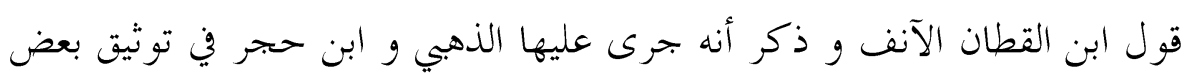
الرواة الذين لم يسبقوا إلى توثيقهم قال ذلك الألباني في نقده لمن انتقد عليه توثيقه الئه

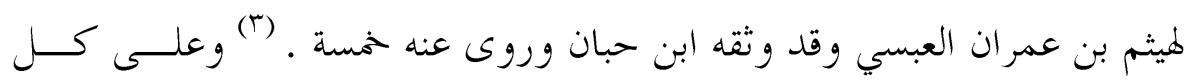

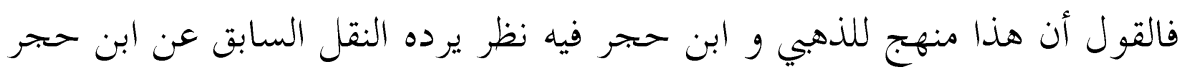

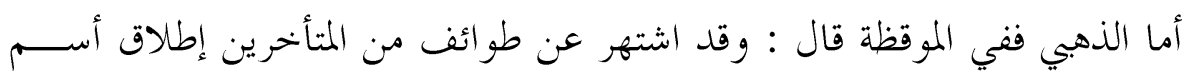

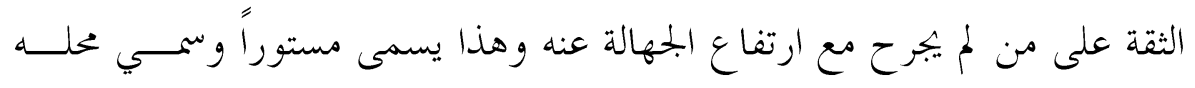
الصدق و يقال فيه : شيخ.

高

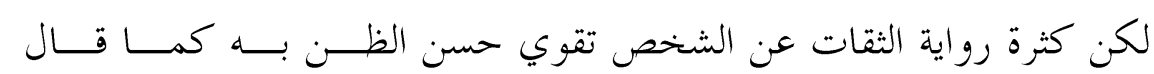
(r) السخاوي. (r) تاسعاً - و تثبت العدالة بتخريج من التزم الصحة في كتابة كالشيخين فإن كانوا من رجال الشيخين يحملون على العدالة حتى يتبين في أحدهم جرح ينظر في أمره

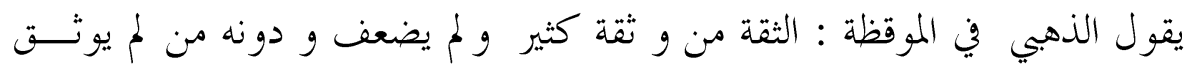

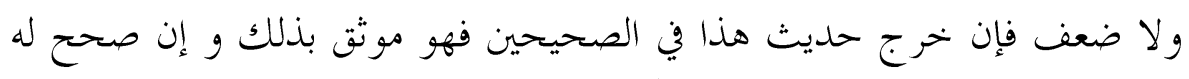

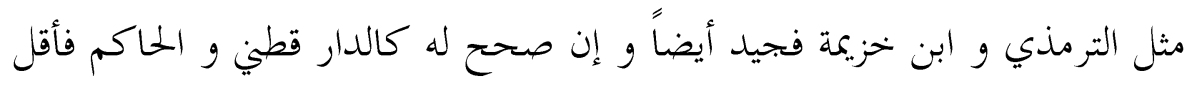

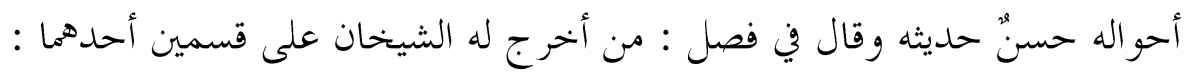

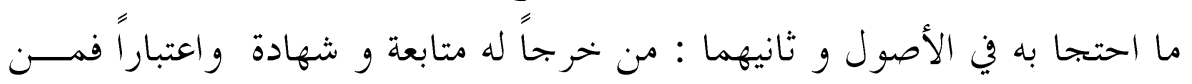

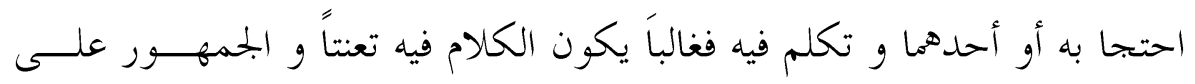

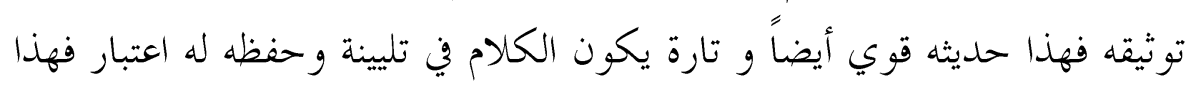

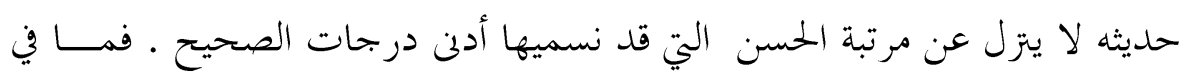

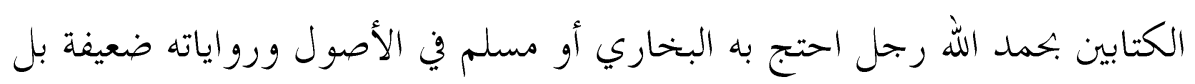

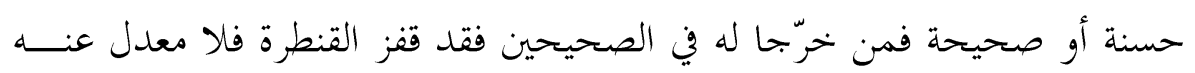

$$
\text { (r) إلا ببرهان بيّن }
$$


لكن أشير إلى أنه ليس كل من التزم الصحة يعتبر من خرَج لــهـ ثنـــة علــى

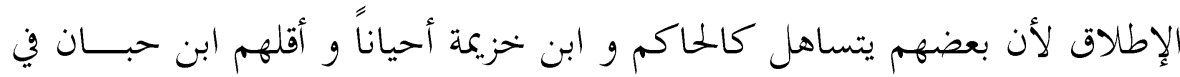

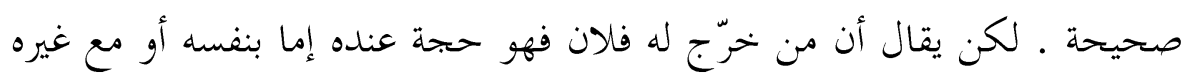

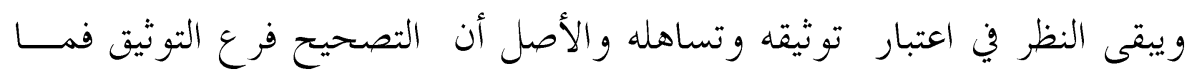
صحح له إلا وهو يوتقه فإن كان المصحح متساهلا فالكثير من العلماء لا يعتبرون 6

عاشراً - مما ذكر أنه تثبت به العدالة اختبار الأحوال، وتتبع الأفعال التي يكصل

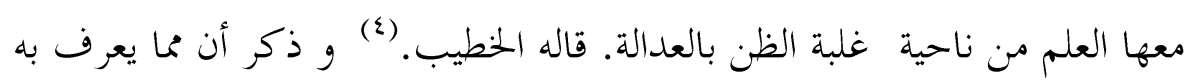

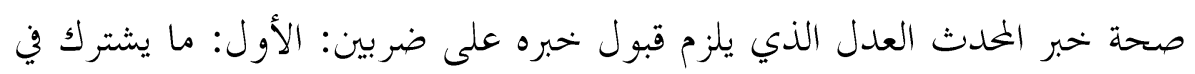

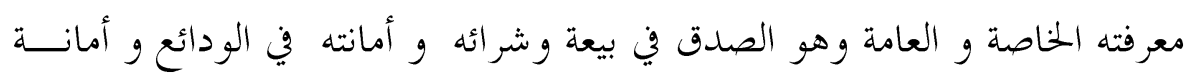
الفر ائض و بتجنب المآتم و الثاني : العلم بما يجب كونه عليه من الضبط و التيقظ و المعرفة بأداء الحديث

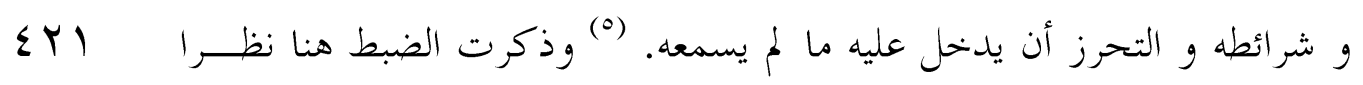

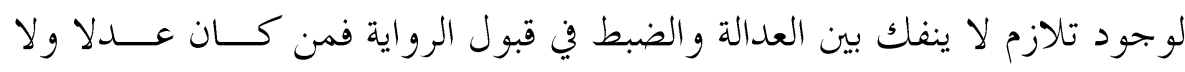
ضبط عنده لا تقبل روايته ومن كان ضابطا وتم القدح في عدالته لا تقبل روايته

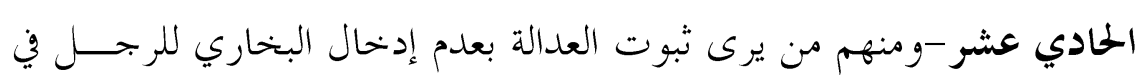

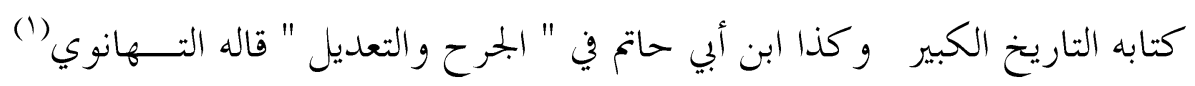

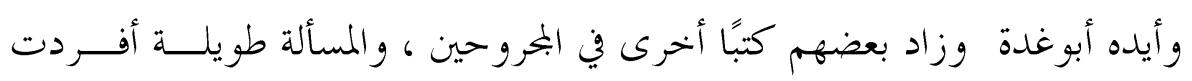

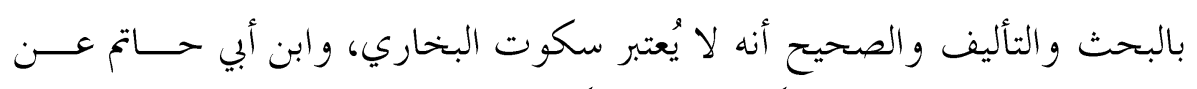

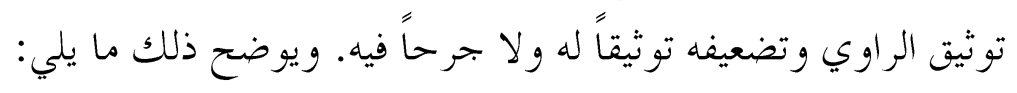

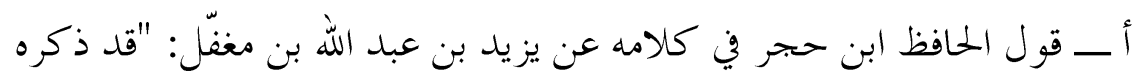

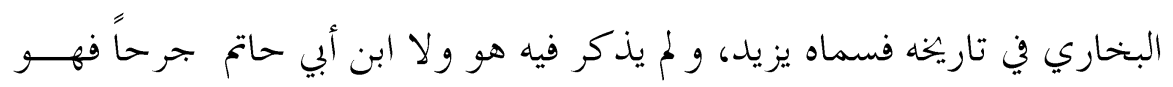
(r) مستور (لبخاري 
ب ــ قول ابن أبي حاتم في بيان منهجه في كتابه (الجرح و التعديل): "... على

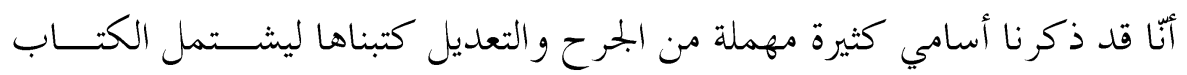
على كل من رُويَ عنه العلم، رجاء وجود الجرح و التعديل فيهم، فنحن ملحقوها

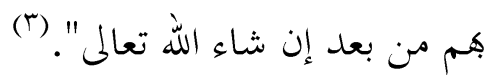

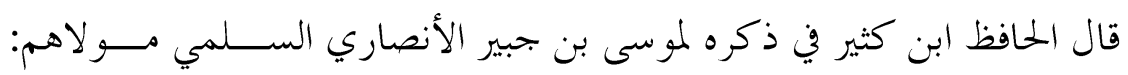

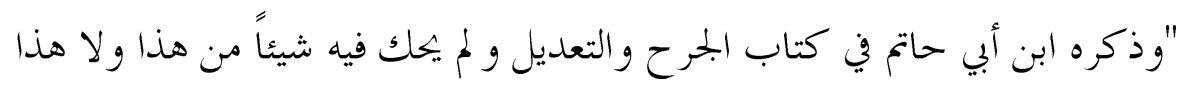

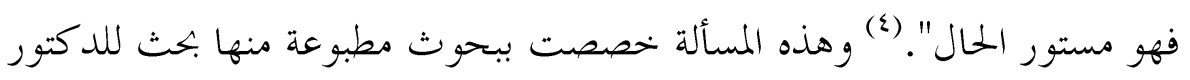
عداب الحمش فأكتفي بما ذكرته

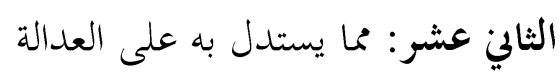

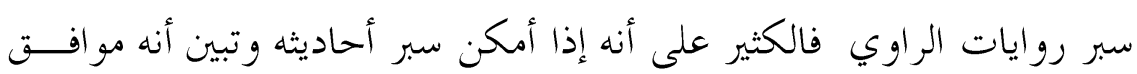

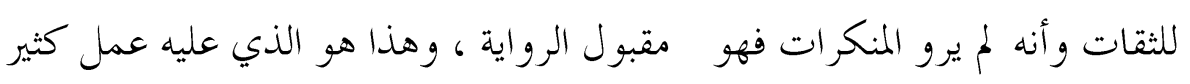

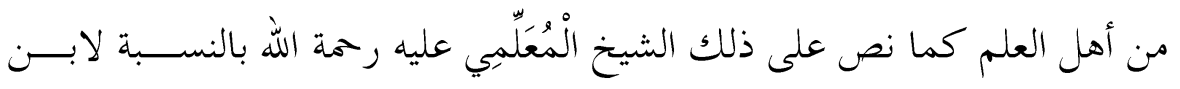

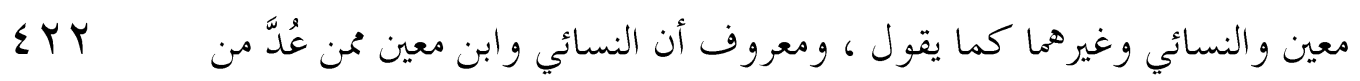

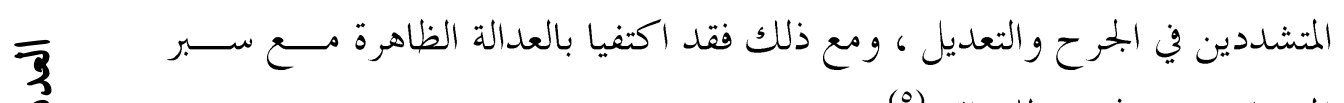

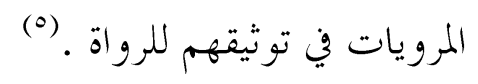

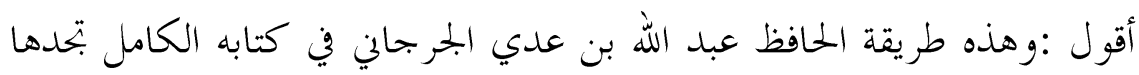

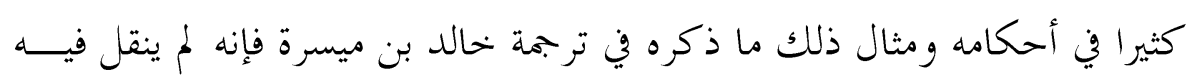

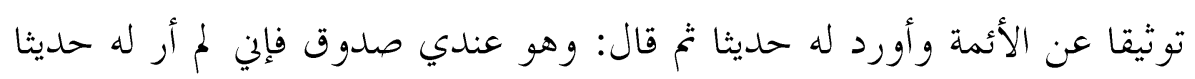

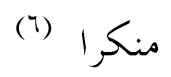

وهذا يدل على أن ابن عدي سبر رواياته و حكم عليه بناء عليها

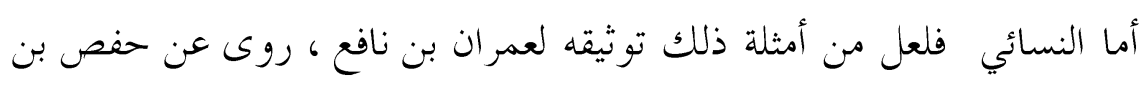
عبيد الله بن أنس بن مالك ، روى عنه بكير بن عبد الله بن الأشج ، قال النسائي:

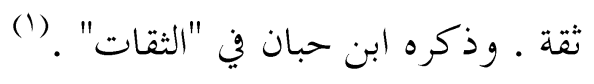


روى له النسائي حديثا واحدا ، رواه من طريق ابن وهب أخبربي عمرو بــن

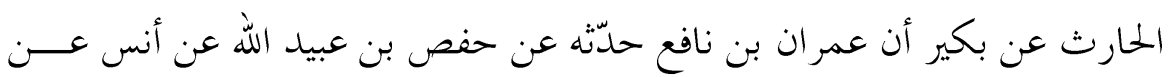

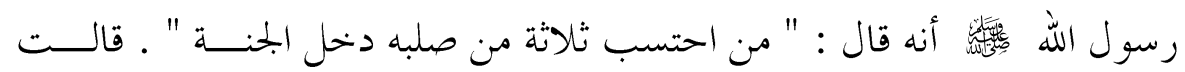

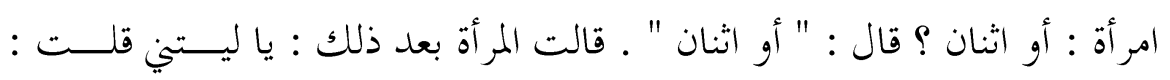

أو أوالحد (r)

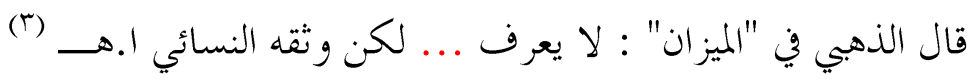

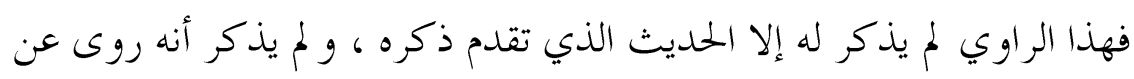

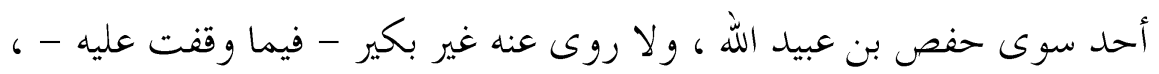

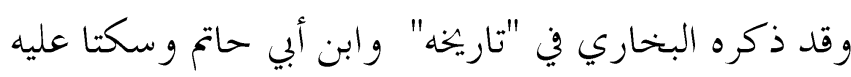

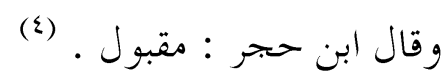

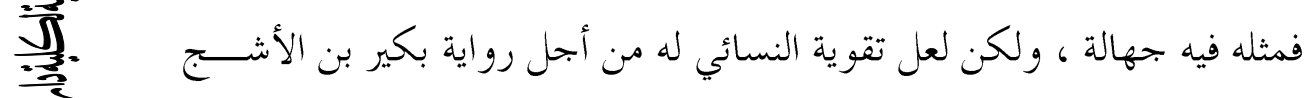

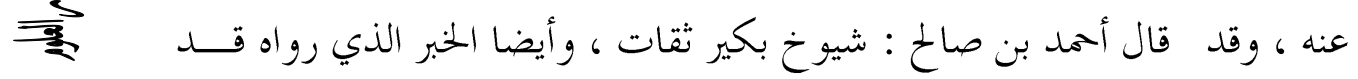

$\sum r r$

جاء من طرق أخرى صحيحة ، و الله أعلم .

3
3
2

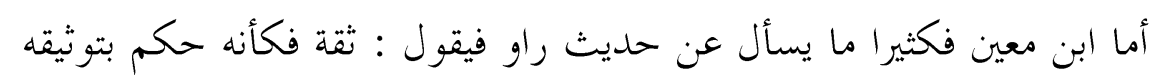
لتتبعه لحديثه انظر مثلا:

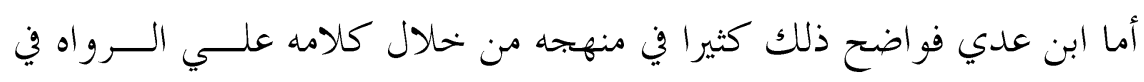
كتابه الكامل وهذا مبسوط في ثنايا الكتاب الثالث عشر: مسألة: تعديل المبهم :-

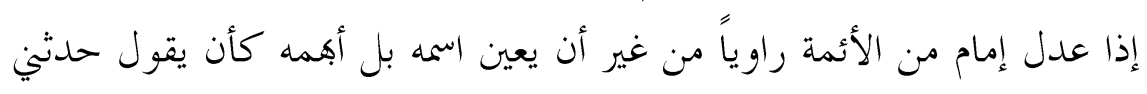

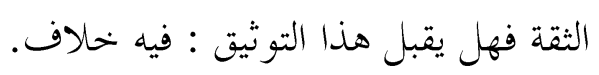

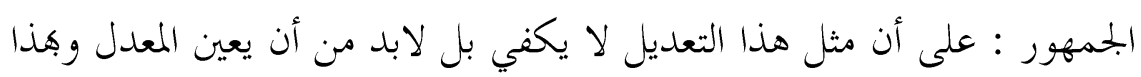

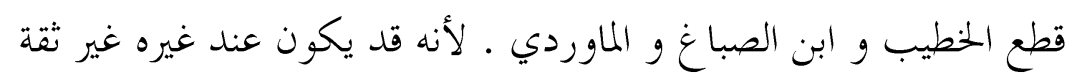

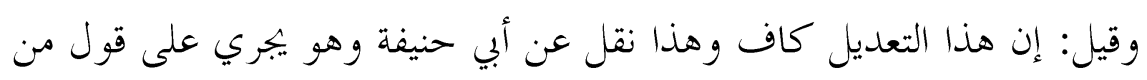

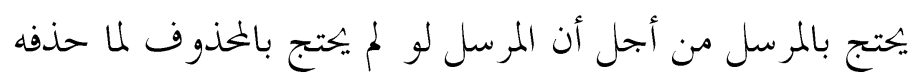


وقيل: إن كان القائل من العلماء البختهدين فيكفي مثل هذا التعديل في حق من

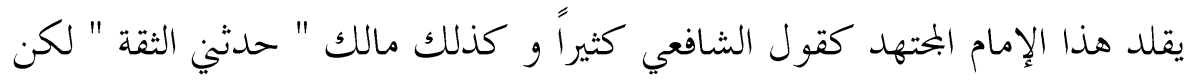
الصحيح القول الأول لأنه لا يلزم من تعديله أن يكون

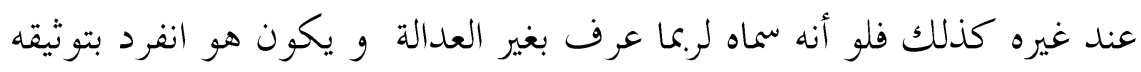

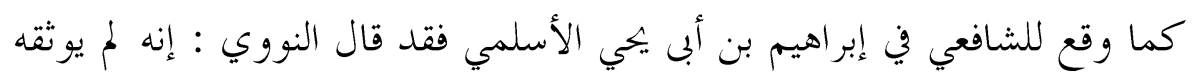

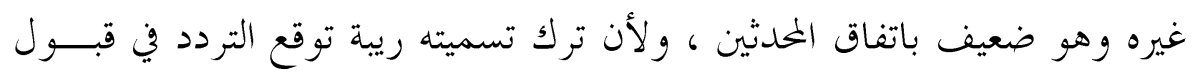
حديثه

مســألة: إذا عمل العالم وفق حديث أو أفتى معقتضاه فلا يعد ذلك تصحيحاً

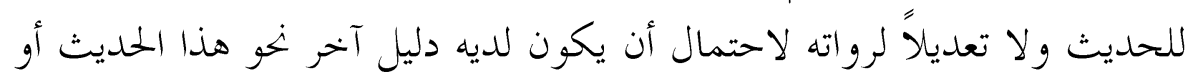

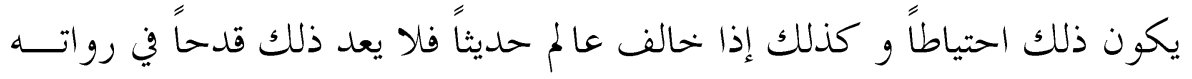

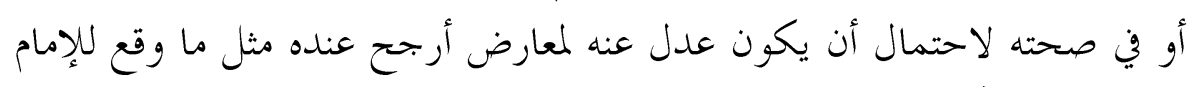

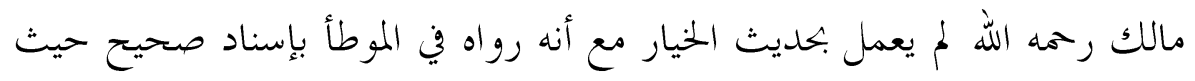

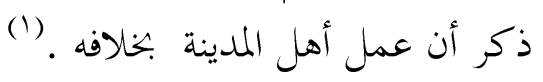

EY

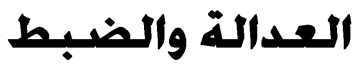

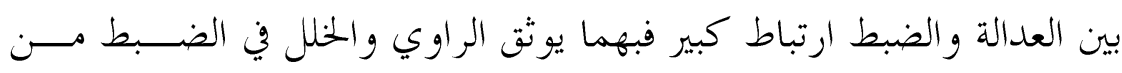

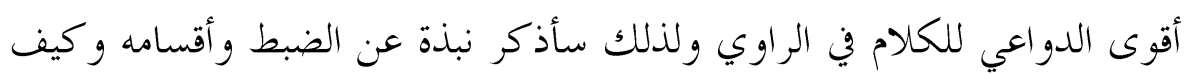
يعرف الون

\section{تعريف الضبط:}

الضبط :هو لزوم الشيء وحبسه،يقال : ضبط الشيء وضبط عليـهـ يضــبطه

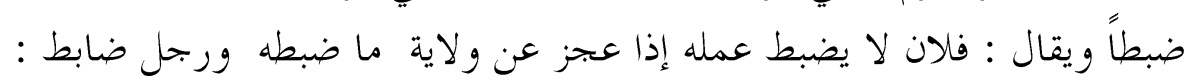
(r). قوي في عمله

والمعنى المر اد عند المحدثين : هو أن يضبط الراوي سماعه ضبطاً لايتـــردد فيــهـ

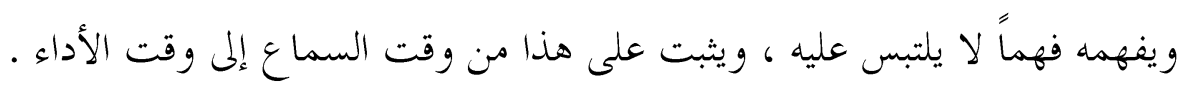

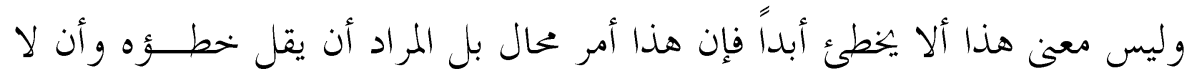

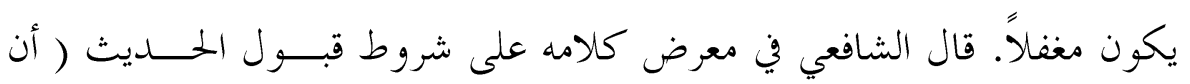


يكون عاقلاً لما يحدث به ، عالمًاً بما يحيل من معاني الحديث من اللفظ وأن يكــــون

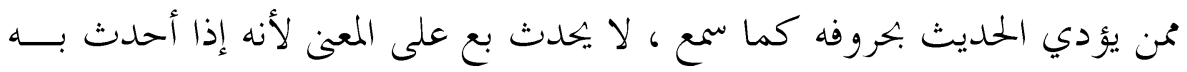

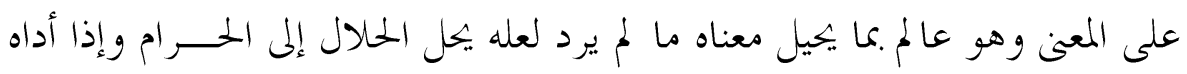

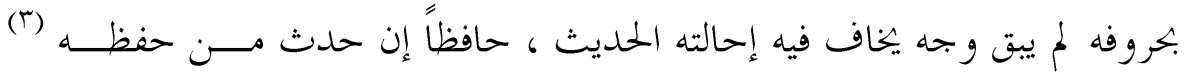

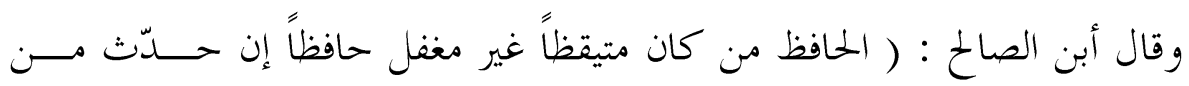

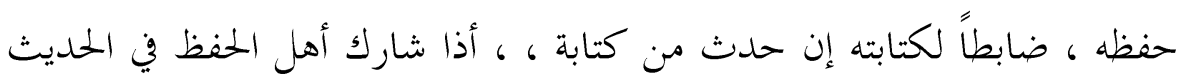

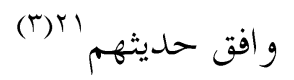

وقال ابن الصلاح : الحافظ من كان متيقظاً غير مغفل حافظاً إن حدث مــــن

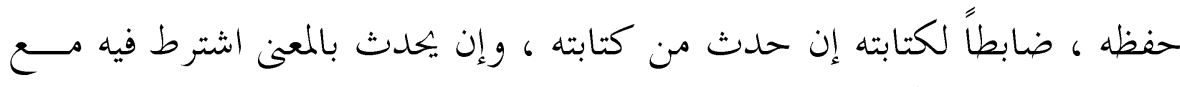

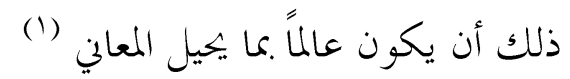

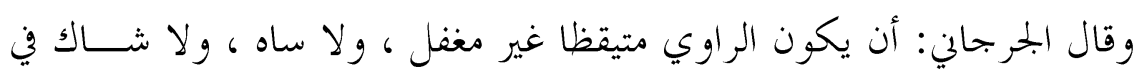

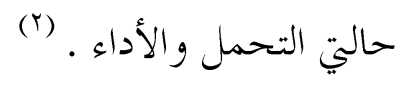

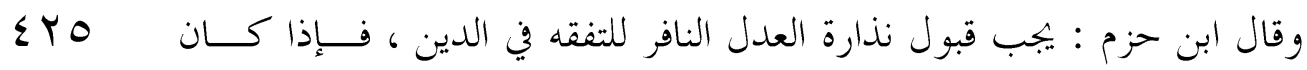

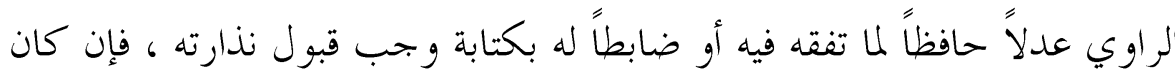
كثير الغلط والغفلة غير ضابط لكتابته فلم يتفقه فيما نفر للتفقه فيه ، و وإذا لم يتفقه

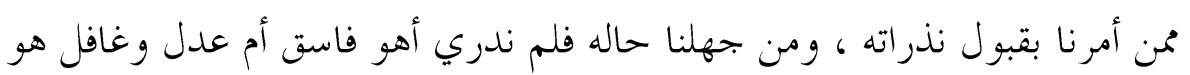

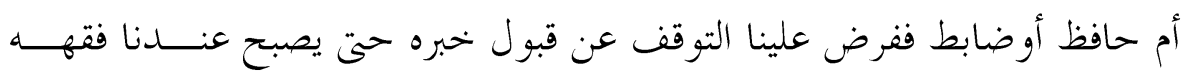

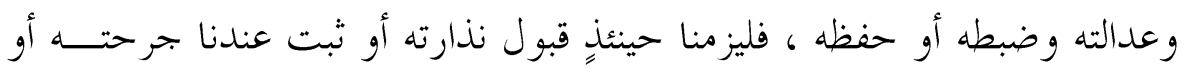

$$
\begin{aligned}
& \text { قال حفظه وضبطه فيلزمنا إطراح خبره. } \\
& \text { الضبط نوعان : ضبط صدر وضبط كتاب : }
\end{aligned}
$$

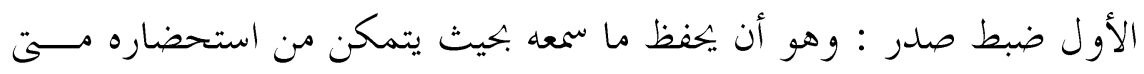

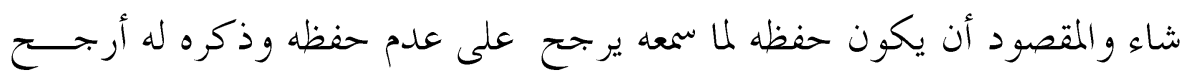

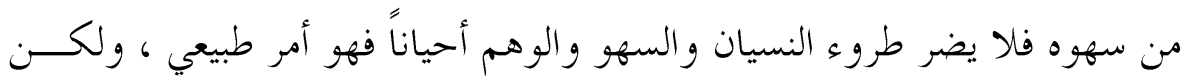


إذا كثر نسيان الراوي ضره ذلك ولذا فإن المحدثين كانوا يتعاهدون حفظهم حستى

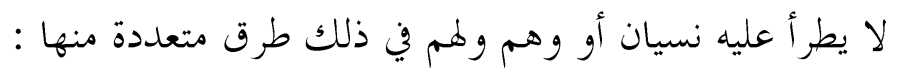

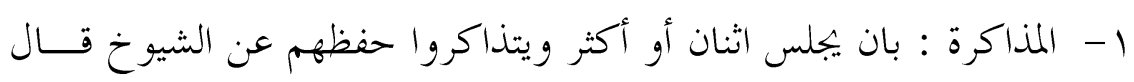
علي رضي الله عنه :تذاكروا الحديث فإنكم إلا تفعلوا

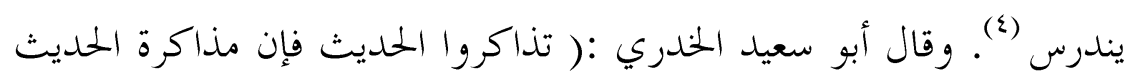

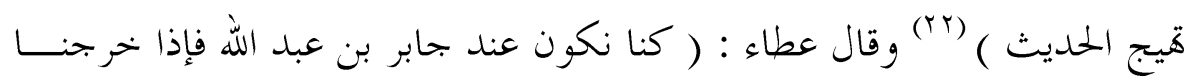

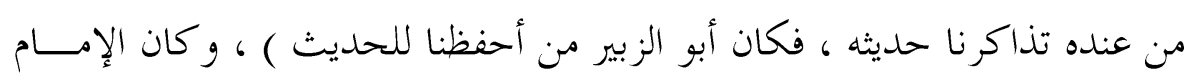

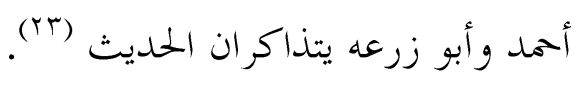

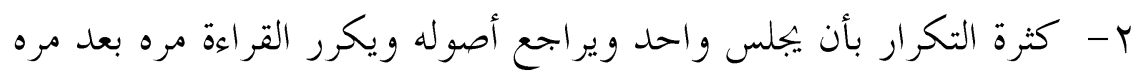

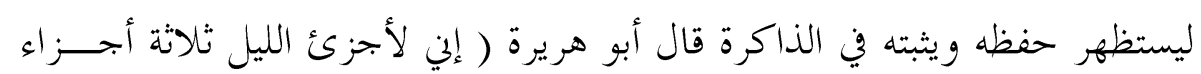

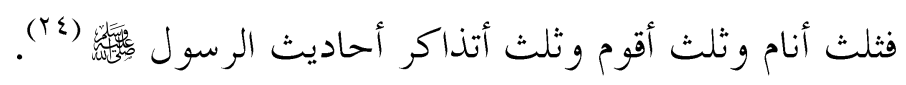

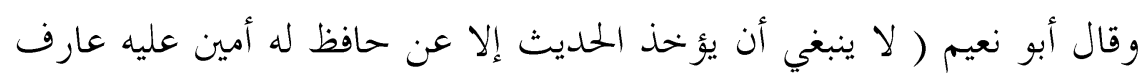

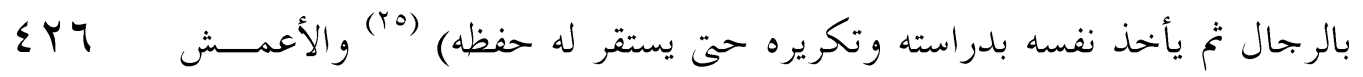

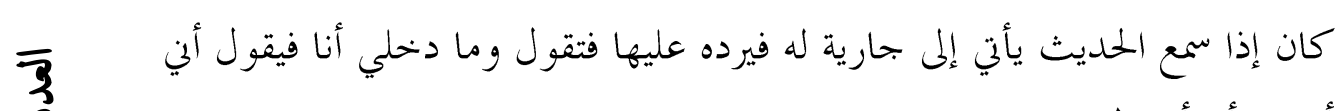

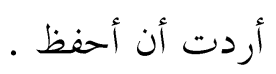

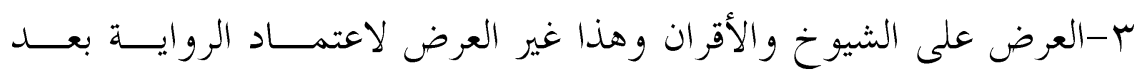

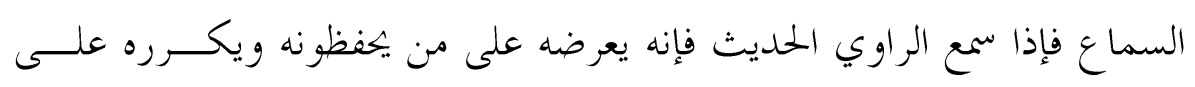
مسامعهم لاستظهار حفظه وزيادة ضبطه للحديث ، قال الأعمش ( كان إبر اهيم

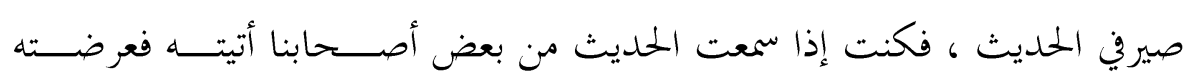
عليه (₹) ع - كثرة التحديث : قال إسماعيل بن رجاء ( كنا بخمع الصبيان فنحســثهم )

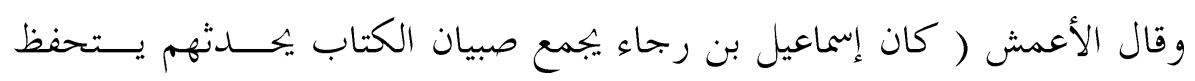
(0) بذلك ( 
الثاني : ضبط الكتاب : وهو صيانته لديه منذ سمعه و كتبــهـ وصــححه إلى أن يؤدي منه وضابط كتابه هو الذي يحافظ عليه ويصونه من التحريف و التبديل ومن صن

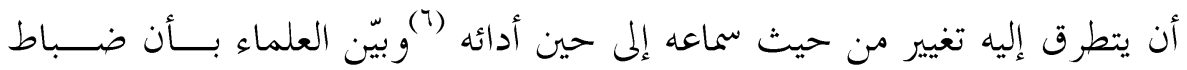

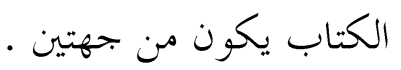

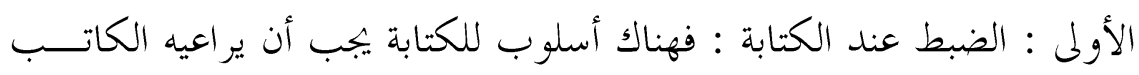

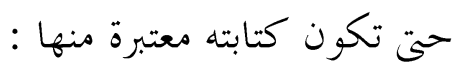
- أن يكون الكتاب مأخوذاً من أصل صحيح · ل -

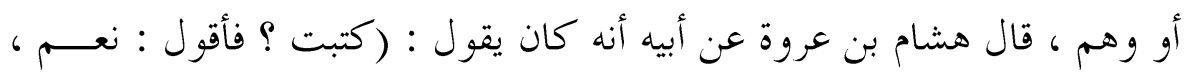

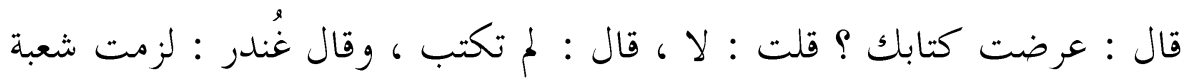

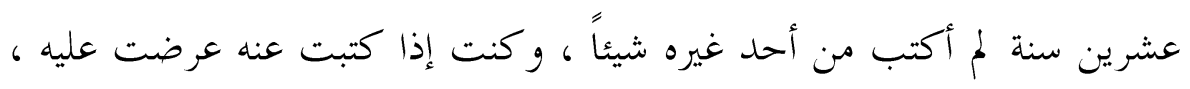

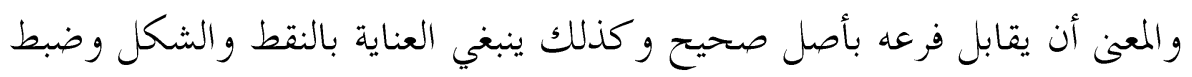
EYV الأسماء وإلحاق السقط ويسمى التخريج (1). كيف يعرف الضبط :

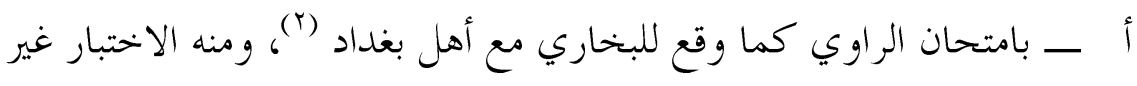

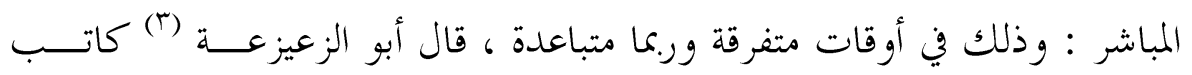

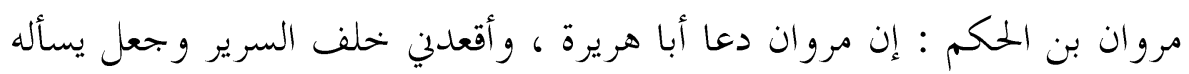

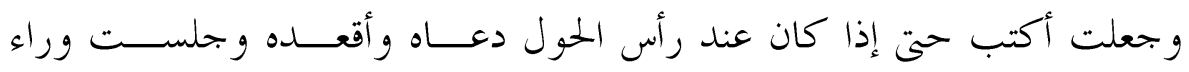

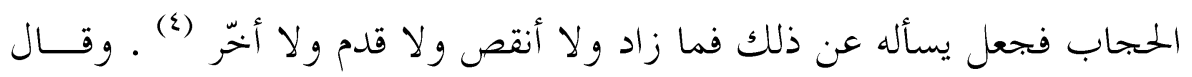

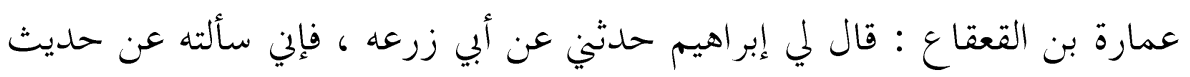

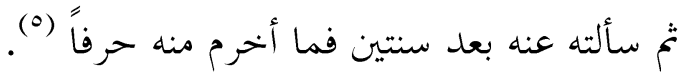

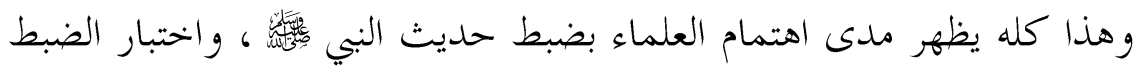

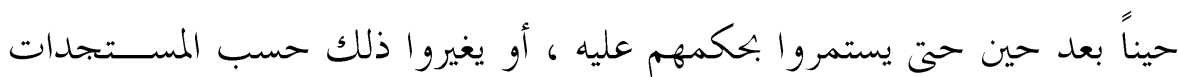
على ضبطه . 
ثانياً : عرض حديثه على الضابطين من أمثاله :

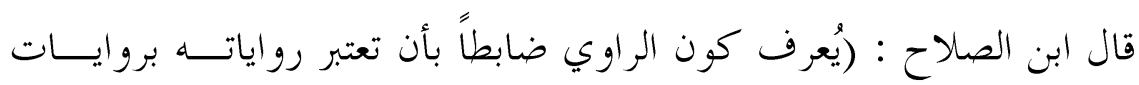

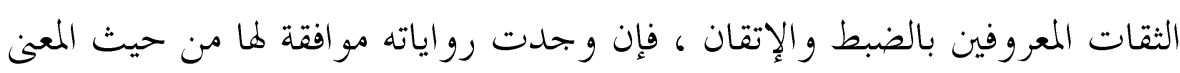

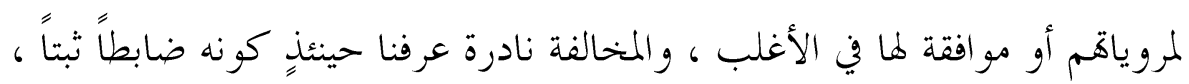

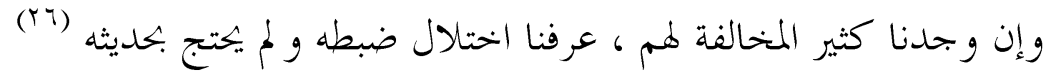

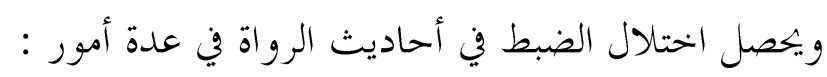

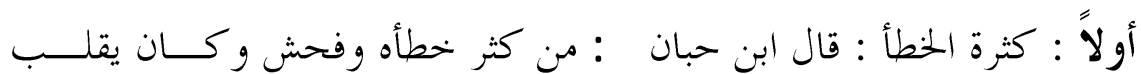

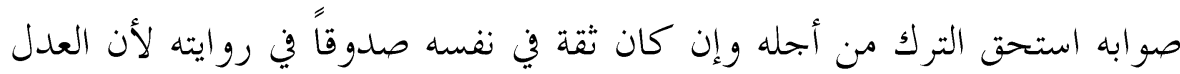

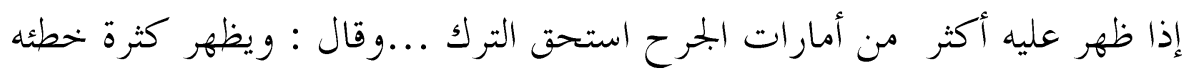

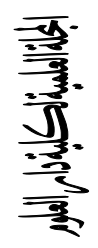

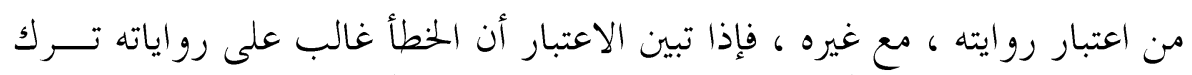

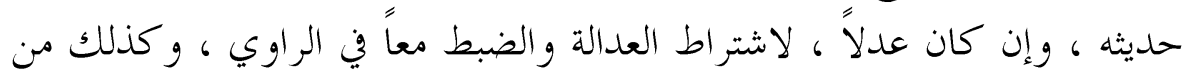

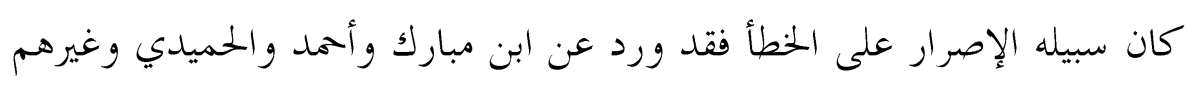

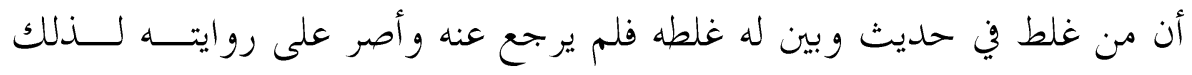
$\varepsilon r \wedge$

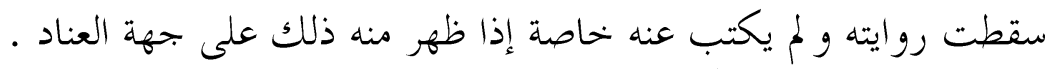

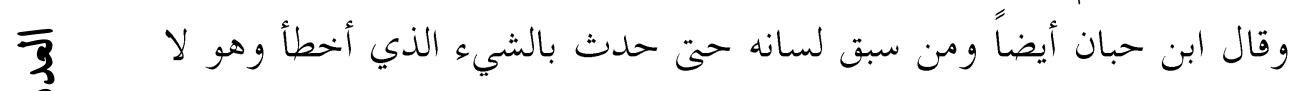

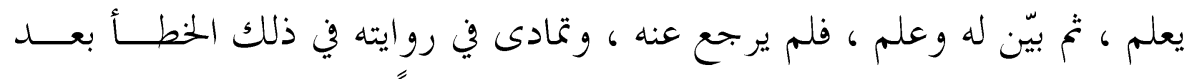

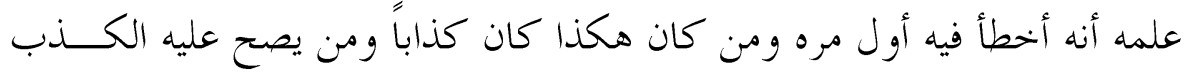

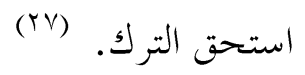

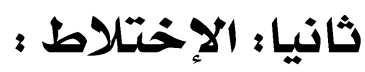

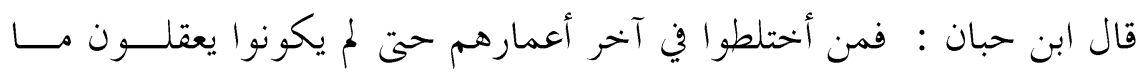

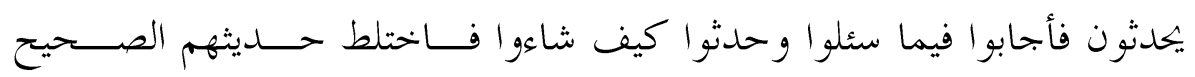

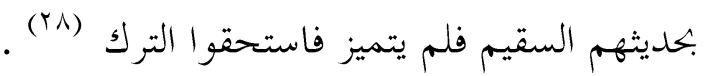

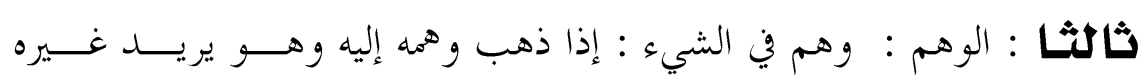

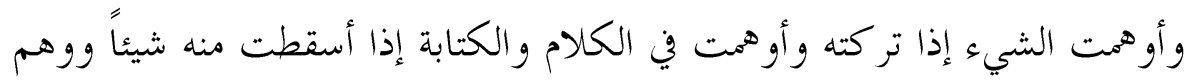

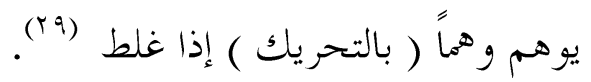




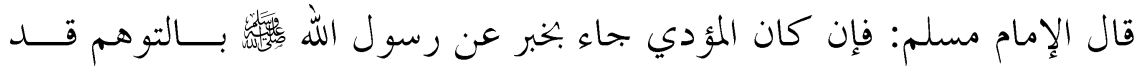

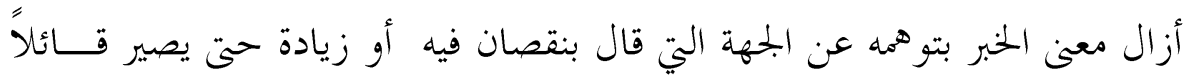

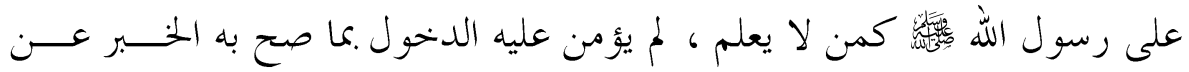

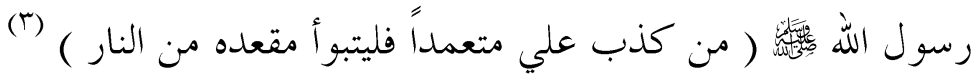

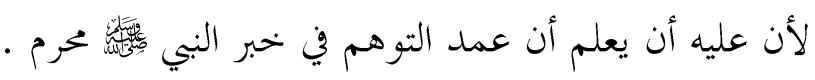

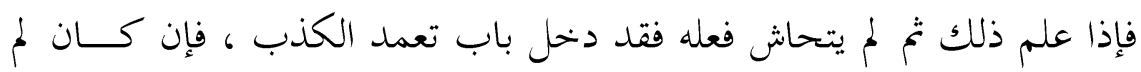

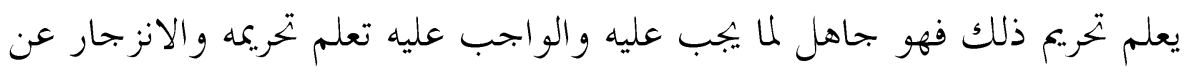
فعله

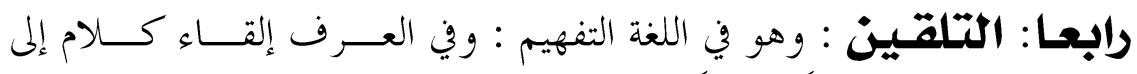

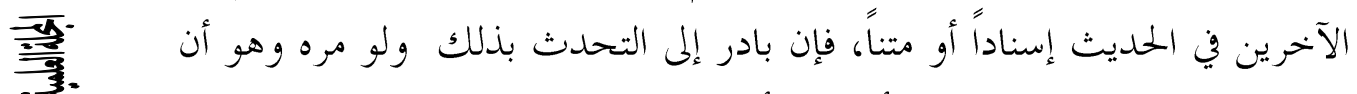

哥.

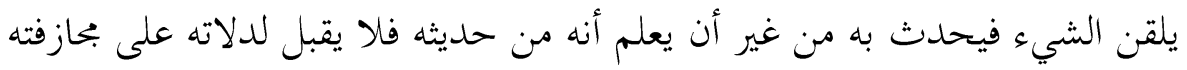

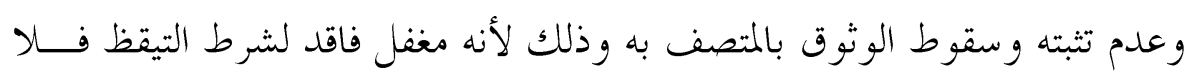

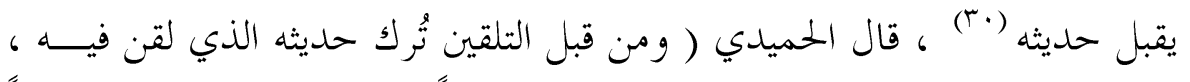

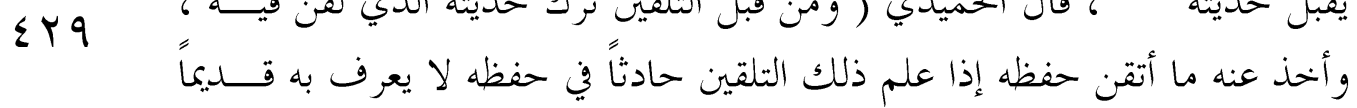

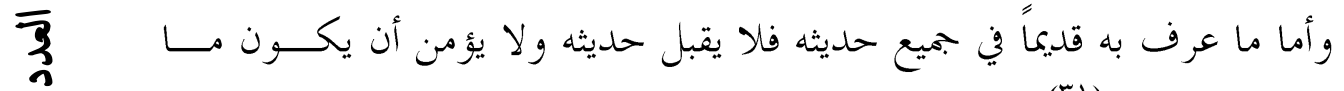

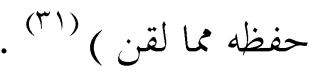
خامسا: كثرة الهخالفتُ : ولا يقبل من كثر الشذوذ في حديثــه أي

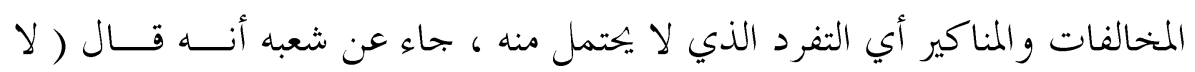

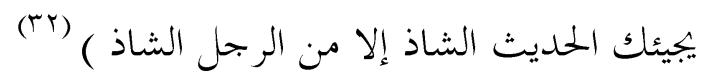
أما إذا كان يحتمل تفرده فحديثه مقبول قال الإمام مسلم رحمه الله تعالى:

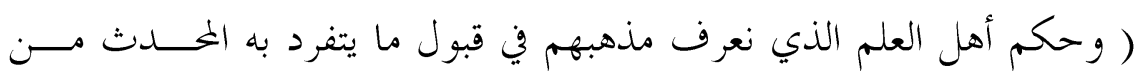

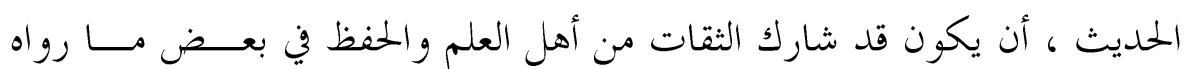

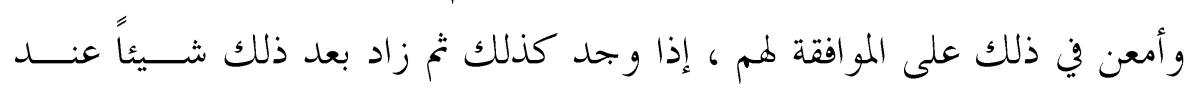
أصحابه قبلت زيادته ) و 
وهذه هي زيادة الثقة وقال : ( ومَن الغالب على حديثه المنكر و الغلط أمسكنا

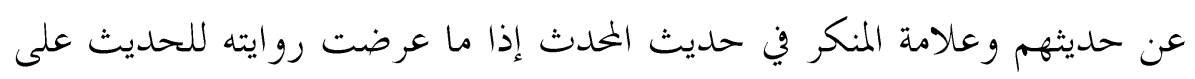

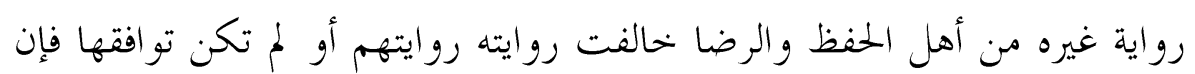

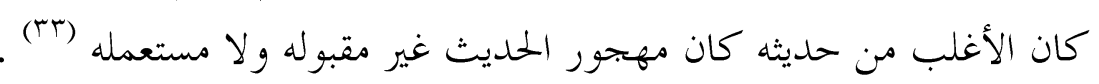

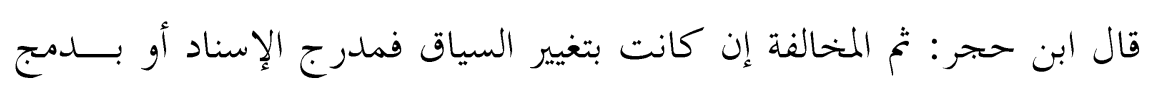

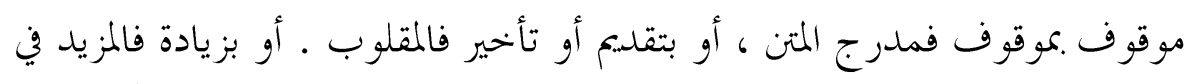

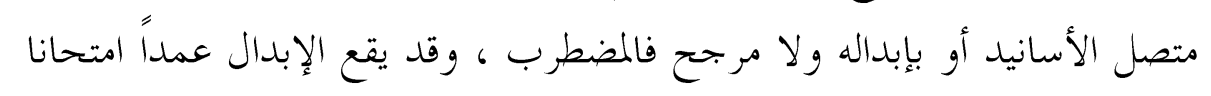

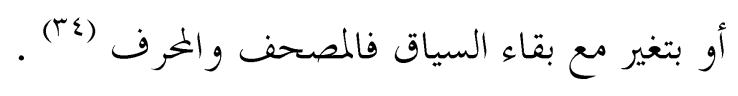

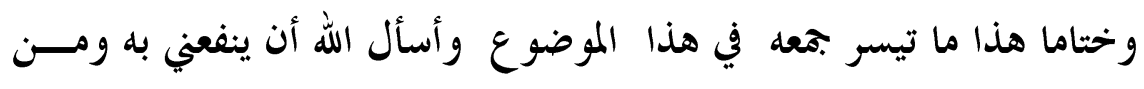

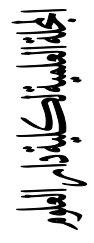

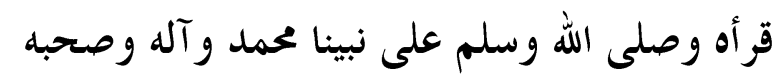

\section{فهرس المسادر والمراجي}

$\Sigma \mu$.

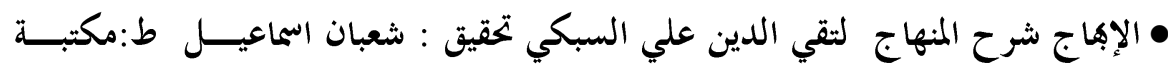

彔 الكليات الأزهرية ـ القاهرة

• إرواء الغليل في تخريج أحاديث منار السبيل. محمد ناصر الدين الألباني. (9) أجزاء.

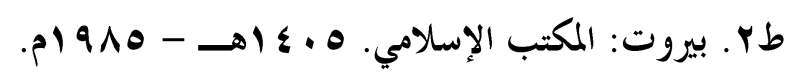

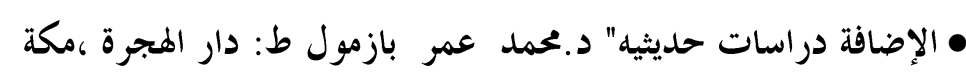

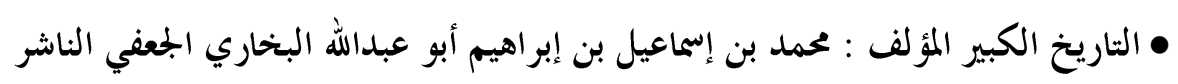
:

• تذكرة الحفاظ شمس الدين أبو عبد الله محمد بن أحمد بن عثمان بن قَيْمســاز الـــهبي

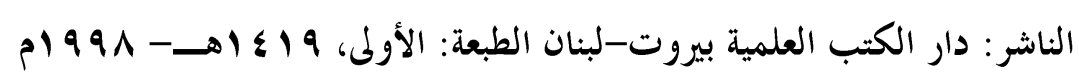
• تفسير القر آن العظيم أبو الفداء إسماعيل بن عمر بن كثير القرشي البصري ثم الدمشقي

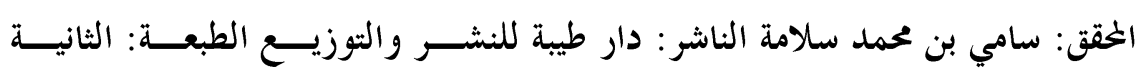

p $1999-\rightarrow 1 \leqslant r$. 
• التقييد والإيضاح شرح مقدمة ابن الصلاح تأليف: زين الدين عبد الرحيم بن الحسين

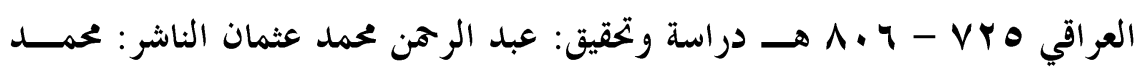

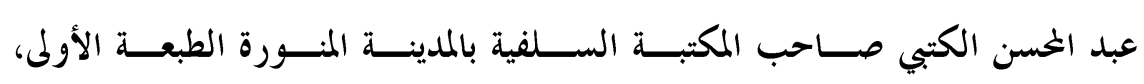

$$
\text { p) } 979 / \rightarrow 1 \% \wedge 9
$$

• تمام المنة في التعليق على فقه السنة المؤلف : محمد ناصر الــدين الألبــالي (المتــــفى :

$$
(\rightarrow) \leqslant r \text {. }
$$

• التمييز المؤلف : الإمام أبي الحُسين مسلم بن الحجاج القُشَيْري النيسابوري.

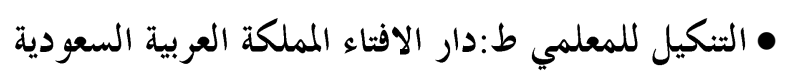

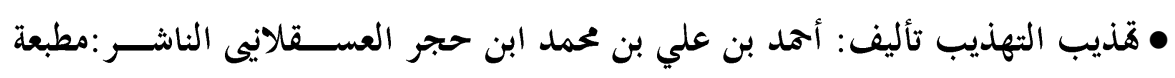

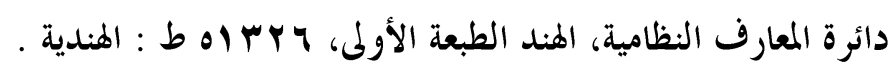
• توثيق السنة في القرن الثاين الهجري للدكتور رفعت فوزي ط: القاهرة • توضيح الأفكار لمعالي تنقيح الأنظار المؤلف : محمد بن إسماعيل الأمير الحسني الصنعاني

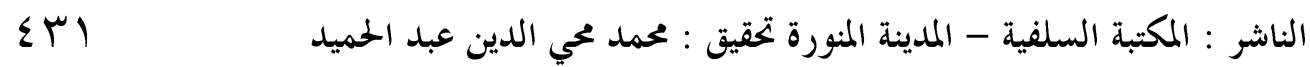

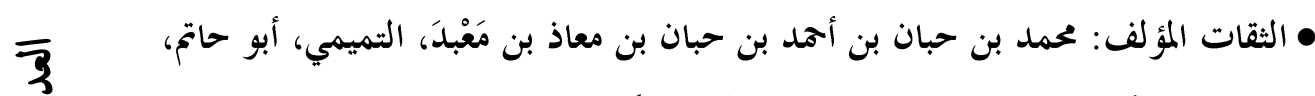

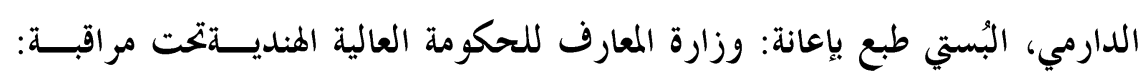

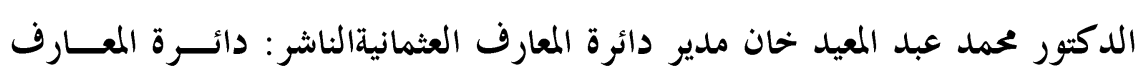

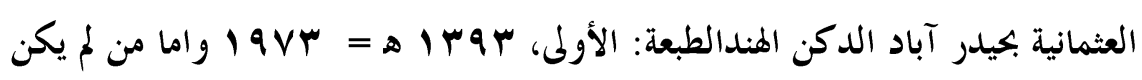

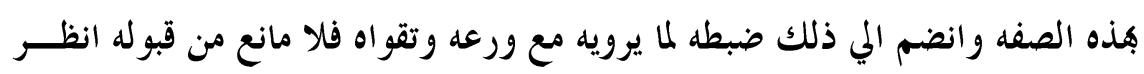

$$
\text { شرح النخبه 10V/104 }
$$

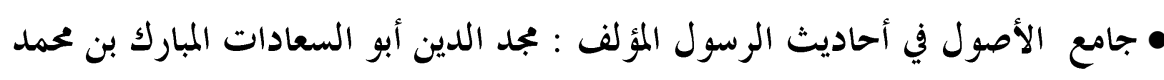

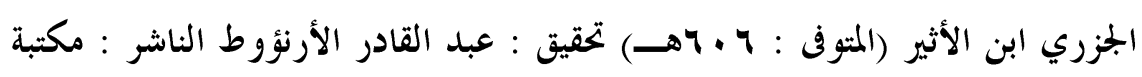

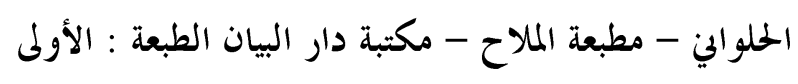


• الجامع الصحيح المختصر المؤلف : محمد بن إسماعيل أبو عبدالله البخاري الجعفي الناشر:

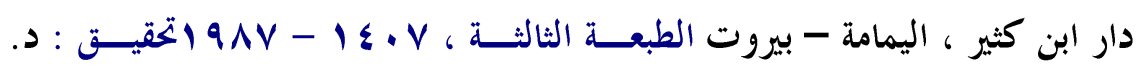

$$
\text { مصطفى ديب البغا }
$$

• الجرح والتعديل أبو محمد عبد الرحن بن محمد بن إدريس بن المنذر التميمي، الحنظلي، البكا، الرازي ابن أبي حاتم الناشر: طبعة مجلس دائرة المعارف العثمانية - بجيدر آباد الدكن -

$$
\text { الهند }
$$

• ديوان الضعفاء والمترو كين ، للإمام الذهبي ت : الأنصاري .ط: بيروت

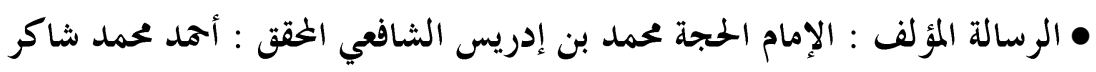

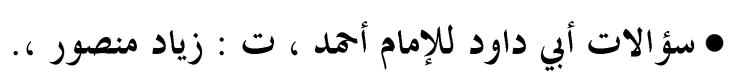

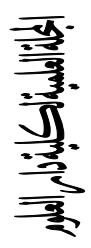

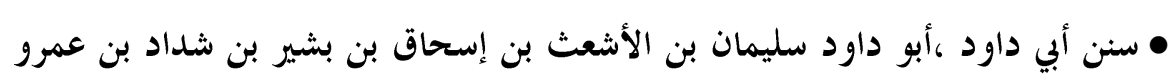

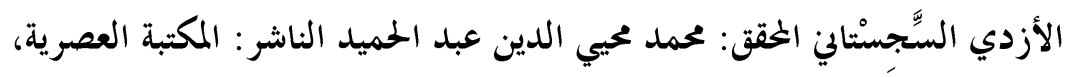

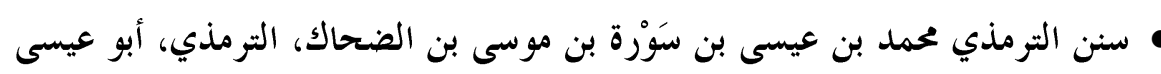

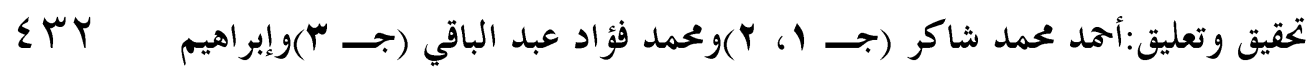

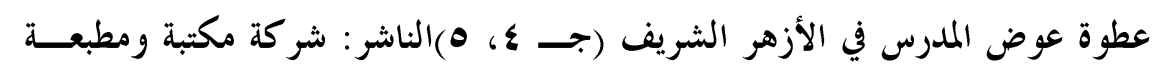

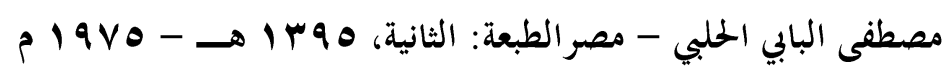

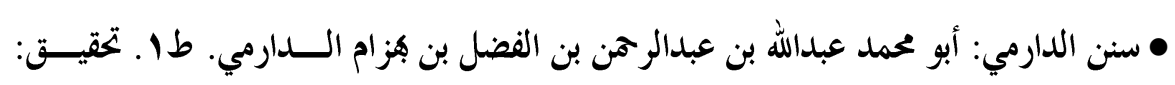

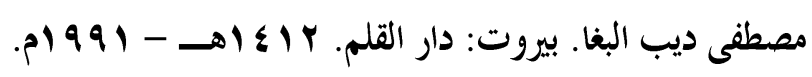
سنن النسائي ( الجبتى ) لإمام أحمد بن شعيب أبو عبدالرمن النسائي، تحقيـقي: عبدالفتاح ابو غده، ط: مكتب المطبوعات، حلب، الطبعة الثانية. • سير أعلام النبلاء المؤلف : شثس الدين أبو عبد الله محمد بن أحمد بن عثمان بن قَائماز

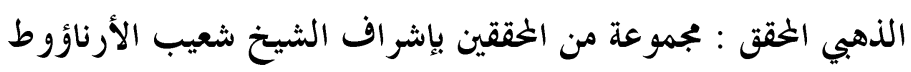

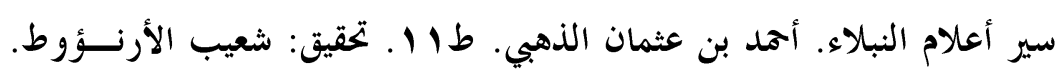

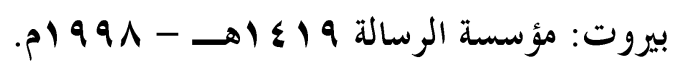
• شرح علل الترمذي للحافظ ابن رجب الحنبلي 
• الصحاح في اللغة المؤلف : الجوهري مصدر الكتاب : موقع الوراق

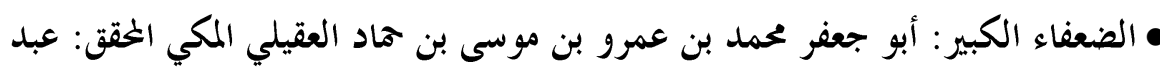

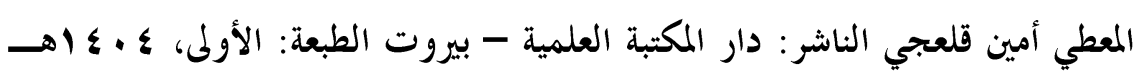

р) $9 \wedge \varepsilon-$

• فتح الباري شرح صحيح البخاري المؤلف: أحمد بن علي بن حجر العسقلالي الناشر:

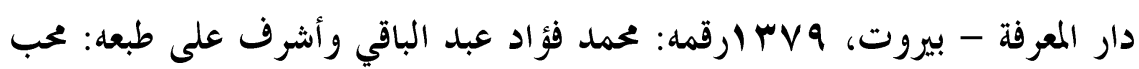
الدين الخطيب عليه تعليقات العلامة: عبد العزيز بن عبد الله بن باز

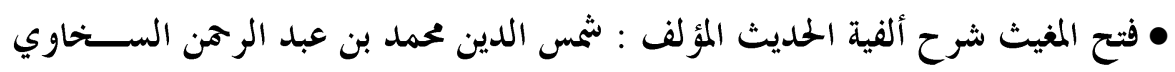

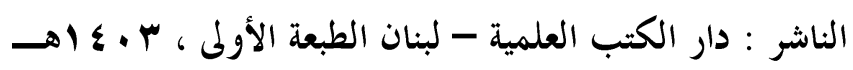

牙

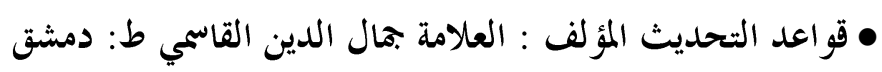

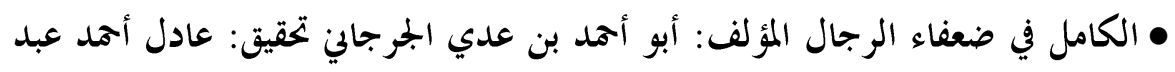
الموجود-علي محمد معوض شارك في تحقيقه: عبد الفتاح أبو سنةالناشر : الكتب العلمية हM

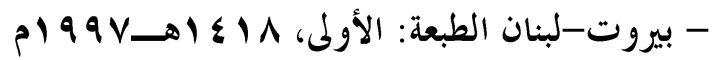
• كتاب السنن الكبرى. البيهقي، أبو بكر أحمد بن حسين بن علــي البيهقـي. · ل ج .

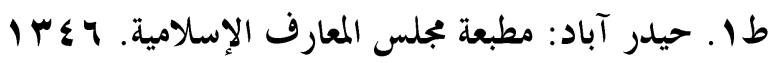

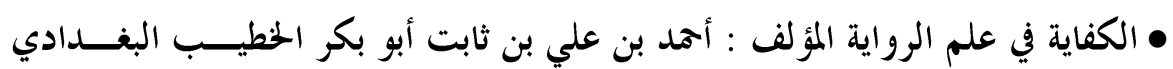

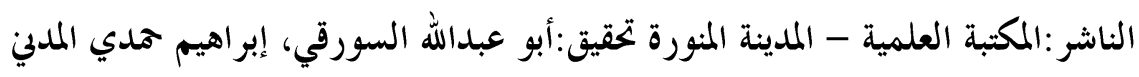

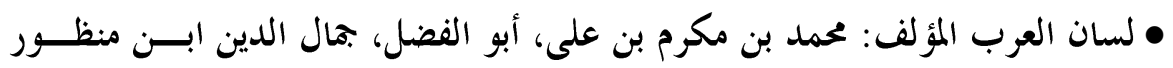

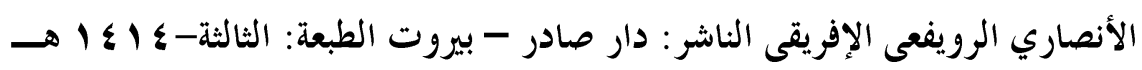

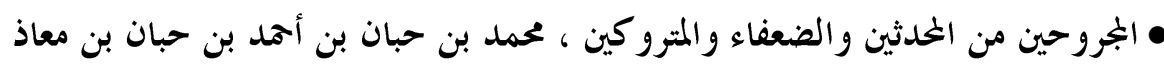

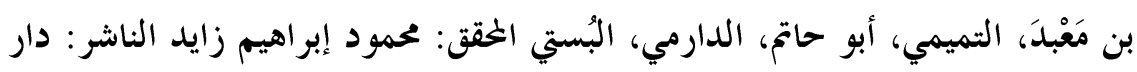

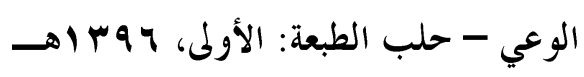
• مر آة الجنان وعبرة اليقظان في معرفة حوادث الزمان المؤلف : اليافعي مصدر الكتاب : موقع الوراق 
• المستدرك على الصحيحين المؤلف: أبو عبد الله الحاكم محمد بن عبد الله بن محمد بــن

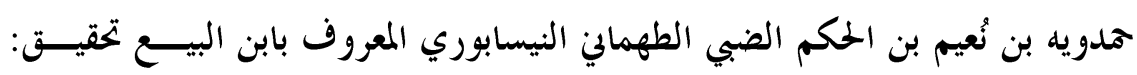

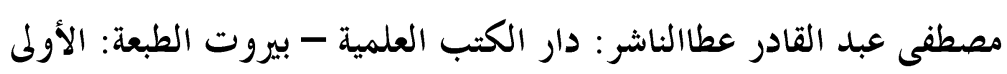

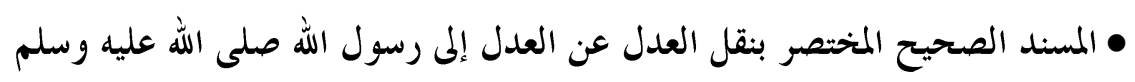

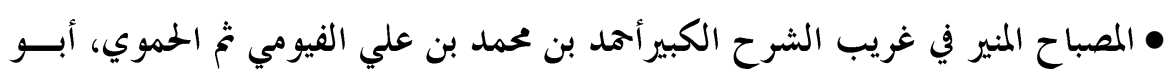
العباس المكتبة العلمية - بيروت

• معرفة علوم الحديث معرفة علوم الحديث المؤلف : أبو عبد الله محمد بن عبد الله الحاكم برو النيسابوري

• المنظظم في تاريخ الأمم والملوك المؤلف: جمال الدين أبو الفرج عبد الرحن بن علي بن

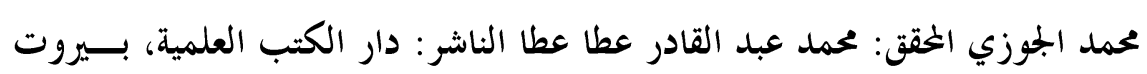

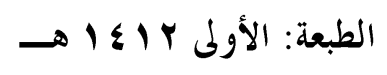

• الموقظة في علم مصطلح الحديث المؤلف : شثمس الدين أبوعبد الله محمد بن أحمد بــن $\varepsilon$ L عثمان بن قَايْماز الذهبي

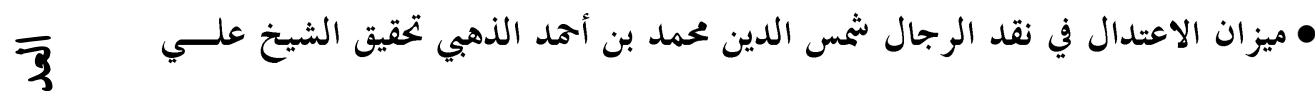

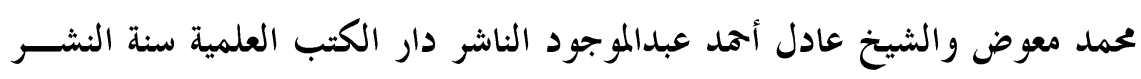

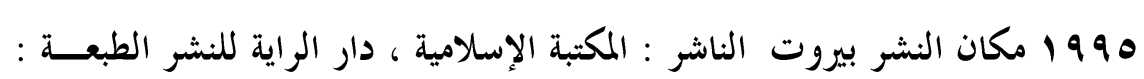

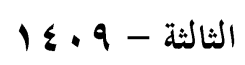

• نزهة النظر في توضيح نخبة الفكر في مصطلح أهل الأثر المؤلف : أبو الفضل أحد بــن

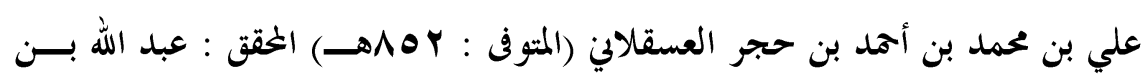

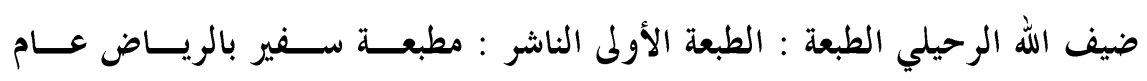

$$
(\rightarrow) \leqslant r r)
$$

• النكت على كتاب ابن الصلاح المؤلف : أبو الفضل أحمد بن علي بن محمد بن أحمد بن حجر العسقلالي الخقق : ربيع بن هادي عمير المدخلي الناشر : عمادة البحث العلمي

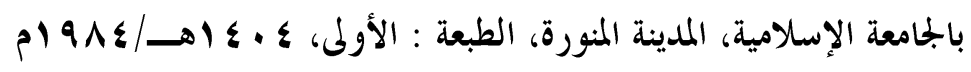


• النهاية في الفتن والملاحم المؤلف : ابن كثير مصدر الكتاب : موقع الوراق

$$
\text { الهوامش والإحالات : }
$$

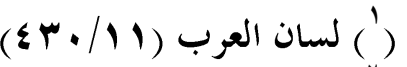

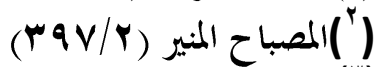

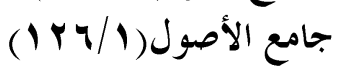

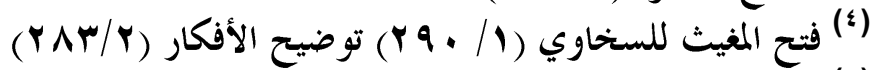

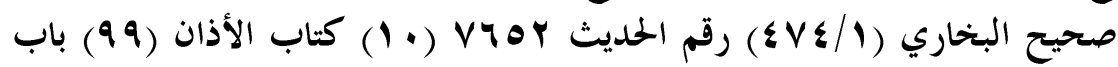

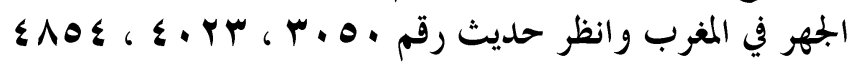

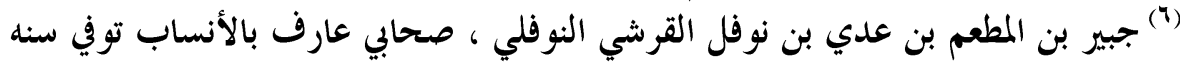

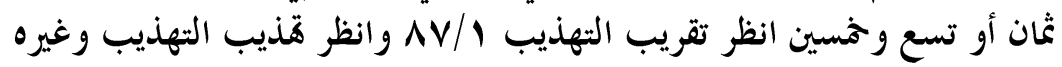

牙-

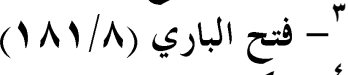

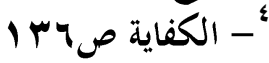

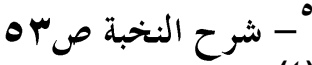

$$
\begin{aligned}
& \text { فتح المغيث (1// ( } \\
& \text { المرجع السابق المغيث }
\end{aligned}
$$

sTo

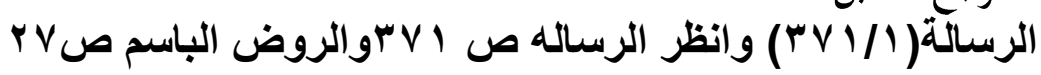

$$
\text { علوم الحديث لابن الصلاح ( }
$$

$\overline{3}$
3
2

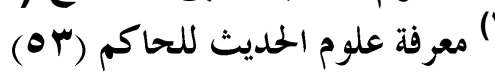

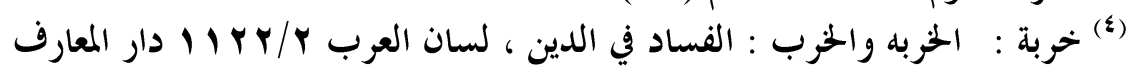

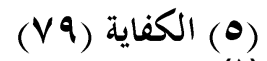

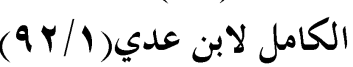

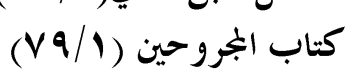

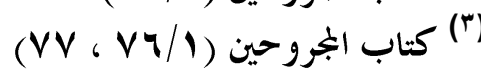

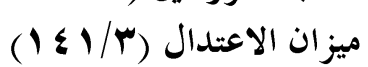

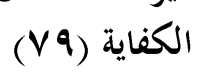

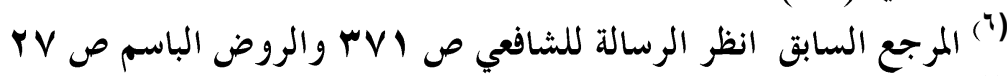

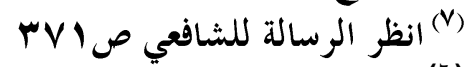

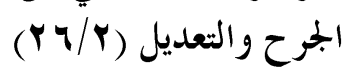

وذكر بعضهم أن قول أبي حنيفة مخصص بصدر الإسلام (القرون المفضلة ) انظر المنهاج

شرح

$$
\text { الإنماج }
$$




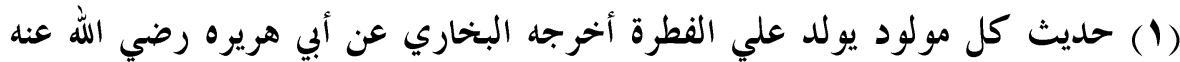

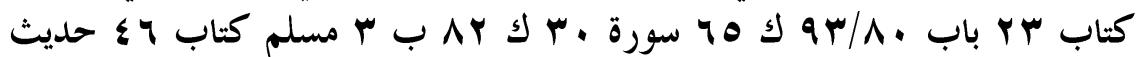

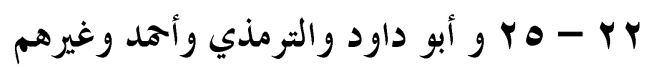

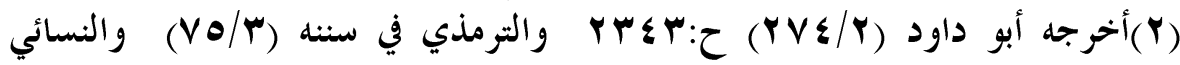

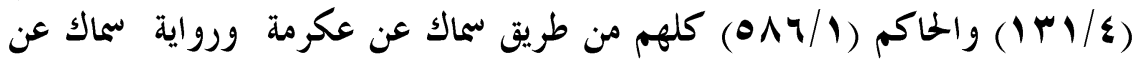

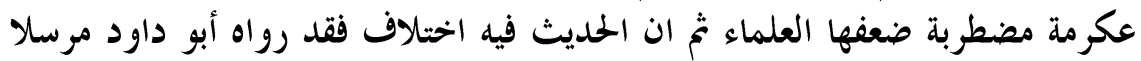

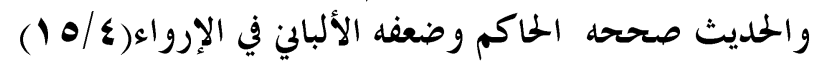

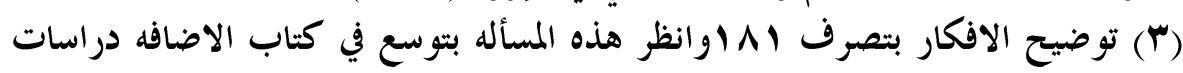

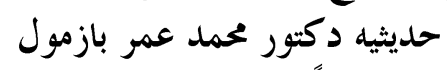

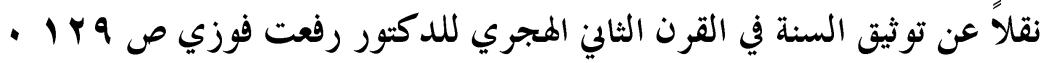

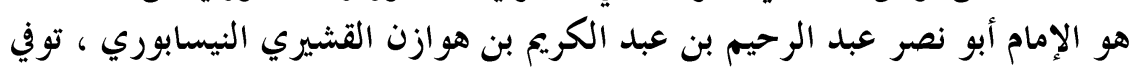

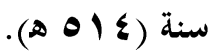

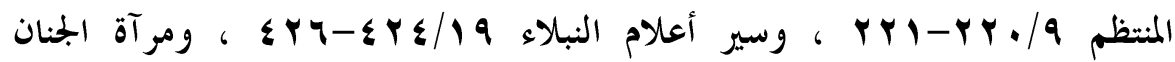

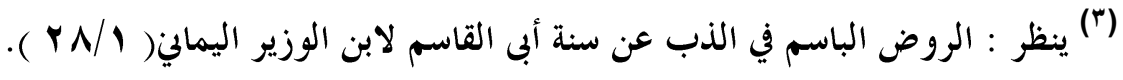

EMr

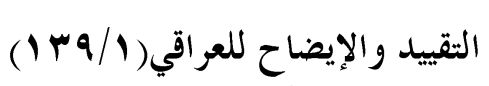

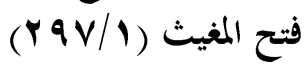

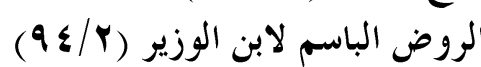

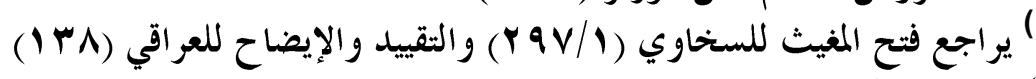

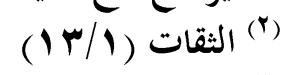

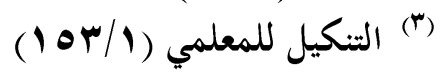

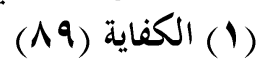

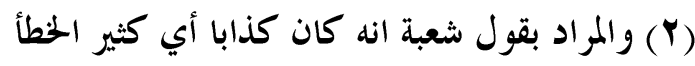

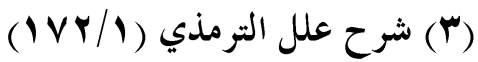

$$
\begin{aligned}
& \text { (૬) انظر الضعفاء للعقيلي }
\end{aligned}
$$

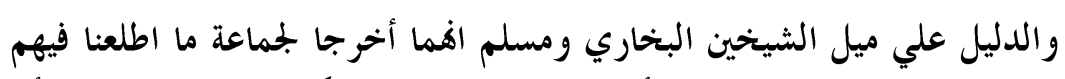

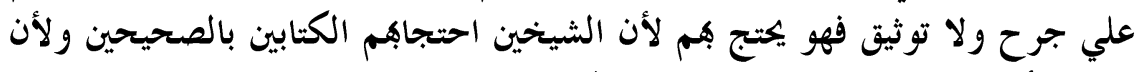

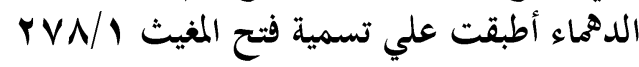

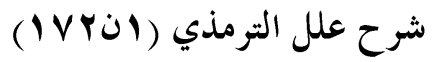

$$
\begin{aligned}
& \text { نقل ذلك ابن رجب في شرح العلل ،ص • }
\end{aligned}
$$




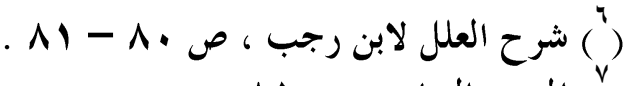

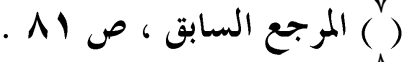

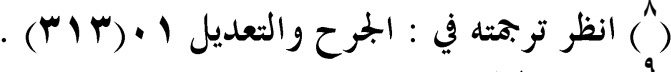

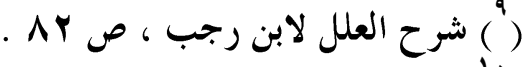

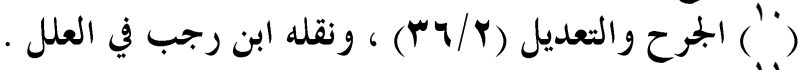

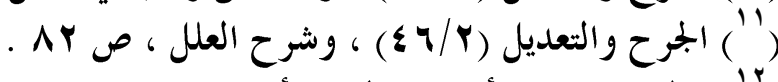

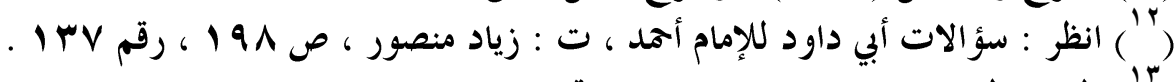

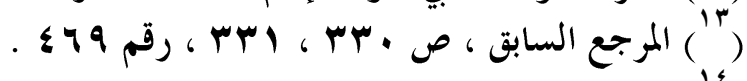

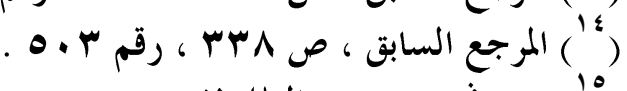

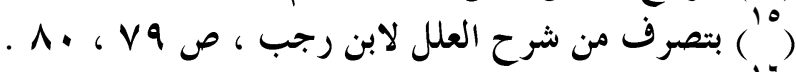

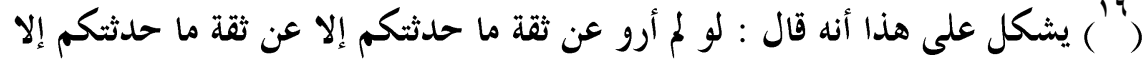

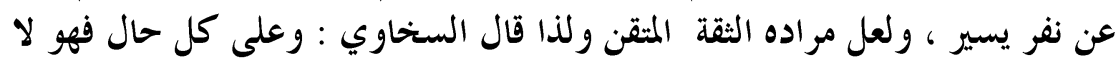

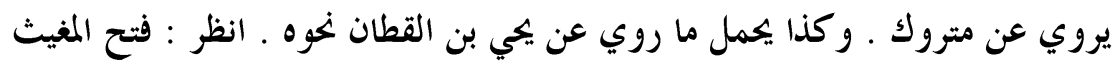

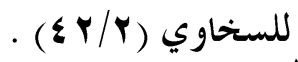

$\varepsilon r V$

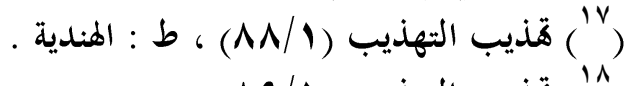

$\overline{3}$
3
2

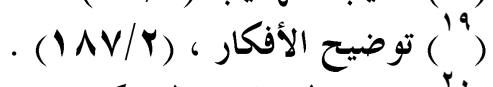

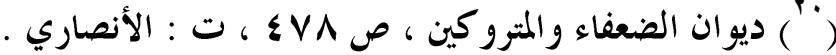

$$
\text { (') }
$$

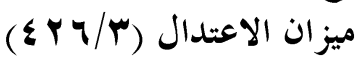

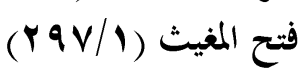

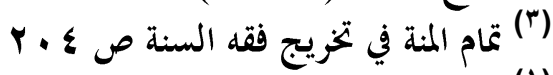

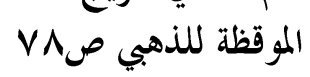

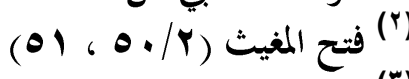

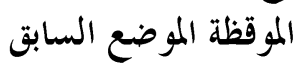

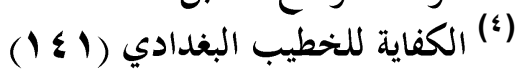

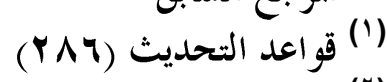

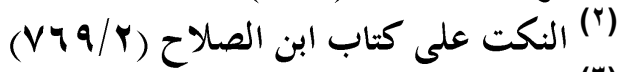

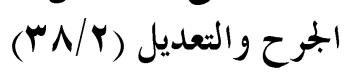

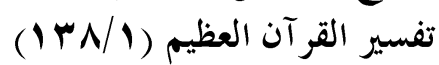




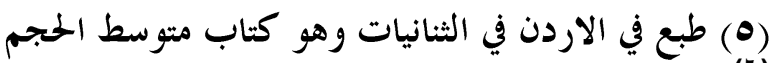

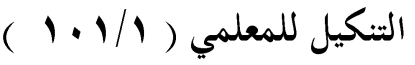

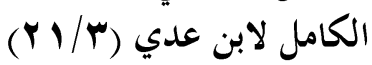

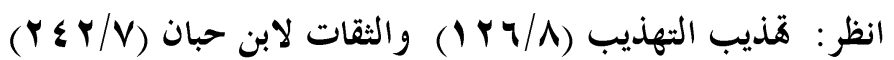

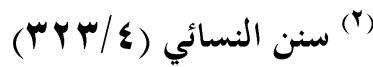

(定)

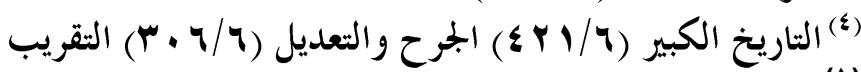

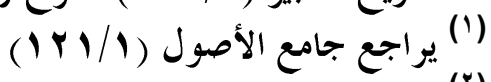

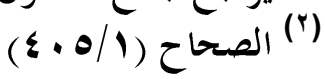

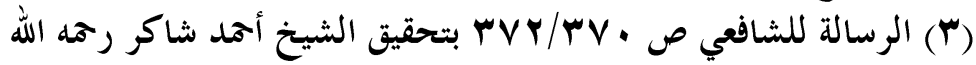

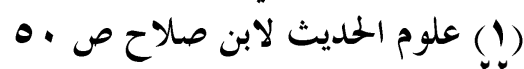

牙

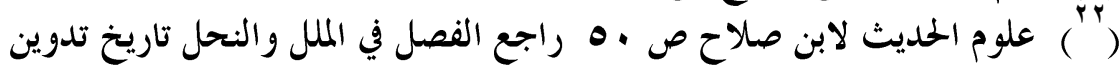

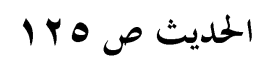

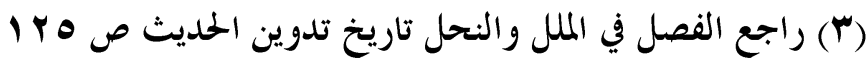

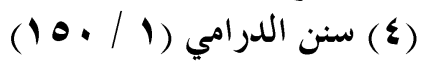

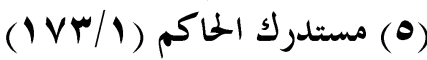

$\varepsilon \mu$

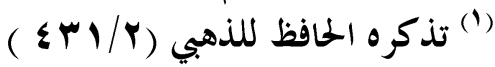

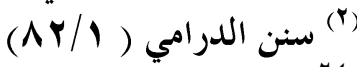

$$
\begin{aligned}
& \text { (Y) }
\end{aligned}
$$

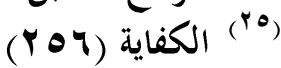

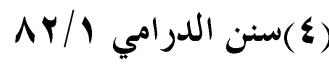

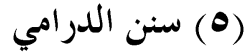

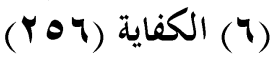

$$
\text { 1. }
$$

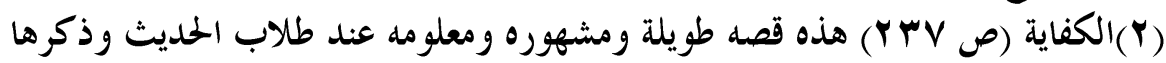

$$
\text { تطويل بدون فائده }
$$

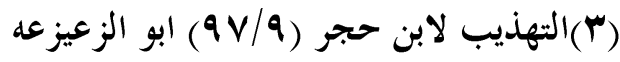

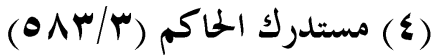

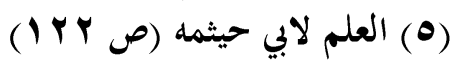

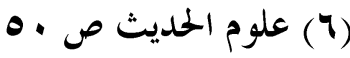




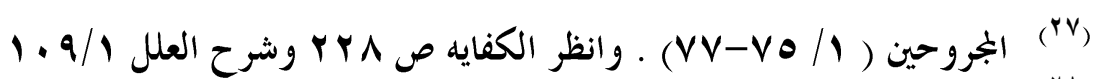

$$
\begin{aligned}
& \text { (r^) }
\end{aligned}
$$

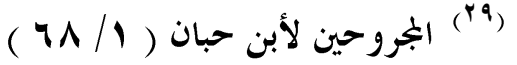

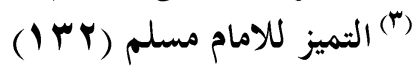

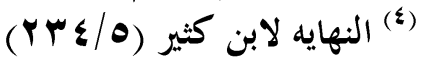

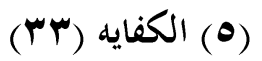

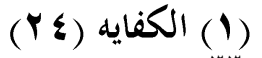

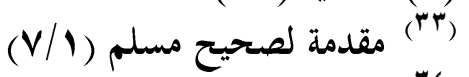

$$
\begin{aligned}
& \text { ( }
\end{aligned}
$$

$\varepsilon r q$ 